\title{
ÉTICA PROFISSIONAL ODONTOLÓGICA: ANÁLISE DO CONHECIMENTO DE DISCENTES E CIRURGIÕES-DENTISTAS, SOBRE O CÓDIGO DEONTOLÓGICO DA PROFISSÃO
}

\author{
FERNANDO TOLEDO DE OLIVEIRA
}

Dissertação apresentada à Faculdade de Odontologia de Bauru, da Universidade de São Paulo, como parte dos requisitos para obtenção do título de Mestre em Odontologia, pelo Programa de PósGraduação em Ortodontia e Odontologia em Saúde Coletiva, Área de Concentração Odontologia em Saúde Coletiva. 


\section{ÉTICA PROFISSIONAL ODONTOLÓGICA: ANÁLISE DO CONHECIMENTO DE DISCENTES E CIRURGIÕES-DENTISTAS, SOBRE O CÓDIGO DEONTOLÓGICO DA PROFISSÃO}

FERNANDO TOLEDO DE OLIVEIRA

Dissertação apresentada à Faculdade de Odontologia de Bauru, da Universidade de São Paulo, como parte dos requisitos para obtenção do título de Mestre em Odontologia, pelo Programa de PósGraduação em Ortodontia e Odontologia em Saúde Coletiva, Área de Concentração Odontologia em Saúde Coletiva.

Orientador: Prof. Dr. Arsenio Sales Peres

\section{BAURU}


Oliveira, Fernando Toledo de

Ol4e Ética profissional odontológica: análise do conhecimento de discentes e cirurgiões-dentistas, sobre o código deontológico da profissão / Fernando Toledo de Oliveira. - Bauru, 2006.

121p.: il.; $31 \mathrm{~cm}$

Dissertação. (Mestrado) - Faculdade de Odontologia de Bauru. USP.

Orientador: Prof. Dr. Arsenio Sales Peres

Autorizo, exclusivamente para fins acadêmicos e científicos, a reprodução total ou parcial desta dissertação, por processos fotocopiadores ou outros meios eletrônicos.

Assinatura:

Data: I__ I

Projeto aprovado pelo Comitê de Ética em Pesquisa em Seres Humanos da FOB - USP, em 26 de abril de 2006: Processo $n^{\circ}$ 27/2006. 


\section{DADOS CURRICULARES}

\section{Fernando Toledo de Oliveira}

11 de abril de 1978

FILIAÇÃO

$1999-2003$

2003

2004

2005-2006

ASSOCIAÇÕES
Nascimento, Bauru-SP.

José Messias de Oliveira Filho

Maria de Fátima Tenório Toledo Oliveira

Curso de Graduação em Odontologia Universidade do Sagrado Coração (19992001) e Universidade Paulista (2002-2003).

Curso de Aperfeiçoamento em Odontologia em Saúde Coletiva, Associação Paulista de Cirurgiões Dentistas, Bauru-SP.

Estágio na Disciplina de Odontologia Sanitária, Área de Treinamento de Campo "Rosa Mondelli"

Curso de Pós-Graduação em Odontologia em Saúde Coletiva, Mestrado, Faculdade de Odontologia de Bauru, USP.

CROSP - Conselho Regional de Odontologia de São Paulo.

SBPqO - Sociedade Brasileira de Pesquisa Odontológica. 


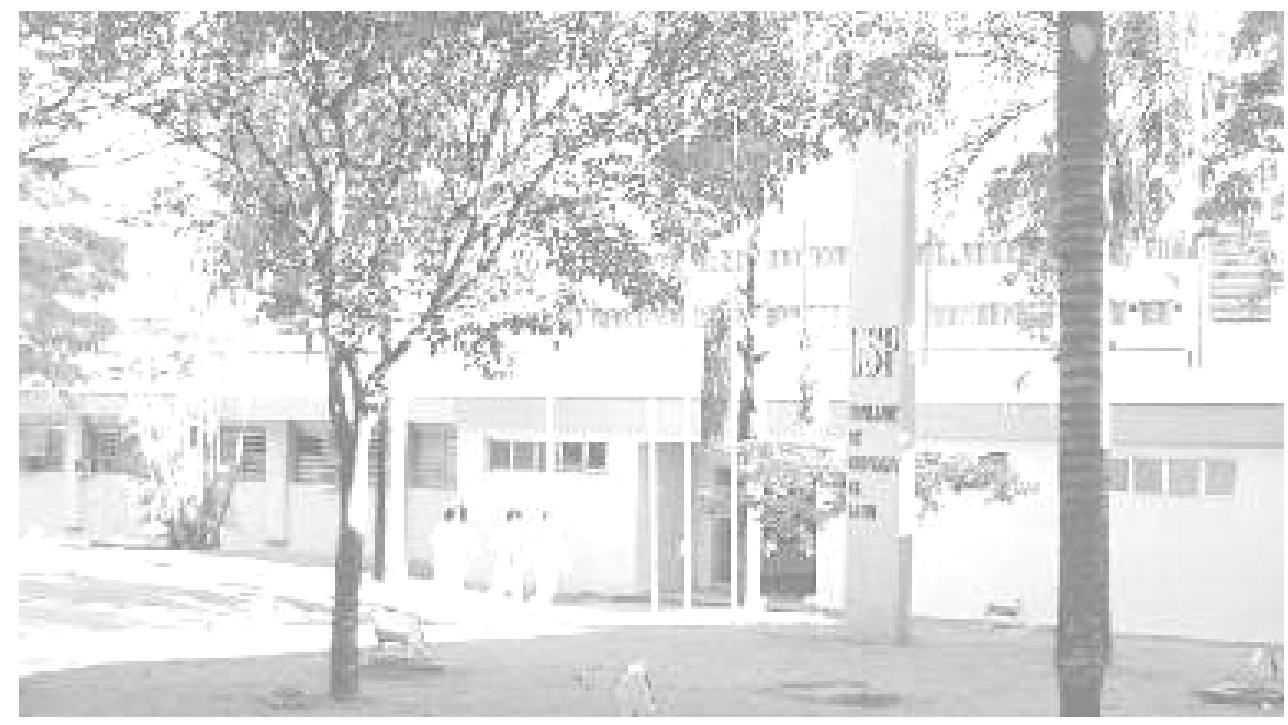

Sem sonhos, as perdas se tornam insuportáveis, as pedras do caminho se tornam montanhas, os fracassos se transformam em golpes fatais. Mas, se você tiver grandes sonhos... seus erros produziram crescimento, seus desafios produziram oportunidade, seus medos produziram coragem. Por isSo, NUNCA DESISTA DOS SEUS SONHOS. 


\section{DEDICATÓRIA}

Dedico este trabalho...

A José Messias de Oliveira Filho, meu PAI, por todos esses anos que você sempre esteve ao meu lado, apoiando minhas decisões, incentivando meus sonhos e amparando-me quando precisei. Mas, principalmente, pelos seus exemplos de trabalho e honestidade, que foram fundamentais para minha formação pessoal e profissional.

À Maria de Fátima T. T. Oliveira, minha MÃE, por todo o amor e carinho incondicionais que você sempre dedicou a mim. Seus exemplos de bondade e sinceridade foram para mim como guias, pois sem eles, não seria possível tomar as decisões mais importantes da minha vida. Graças ao seu empenho e sacrifício, foi possivel chegar ao fim de mais esta etapa.

A Deus, pelo privilégio de ter PAIS como estes. 


\section{AGRADECIMENTOS ESPECIAIS}

À minha esposa, Beatriz, por seu apoio, compreensão e sacrifício. Sem você ao meu lado, me incentivando nas horas de maior desânimo, seria impossível superar mais este obstáculo.

Aos meus filhos, Leonardo e Enrico, por terem trazido tanto amor e alegria para minha vida. O simples fato de vocês existirem, faz com que me empenhe, cada vez mais, em atingir meus objetivos.

A todos meus familiares, pais, avós, tios, irmã, sobrinha, primo, cunhados, sogros. Seriam necessárias inúmeras páginas desse trabalho para expressar todo meu agradecimento a vocês. Certamente, cada um colaborou, de forma direta ou indireta, para realização deste projeto, mais que isso, vocês foram a retaguarda que eu precisava para vencer mais esta batalha.

Ao meu orientador, Professor Arsenio Sales Peres, por acreditar em meu potencial, empenhando-se ao máximo para que fosse possível meu ingresso na Pós-Graduação da FOB. E, principalmente, por todos os ensinamentos a mim passados, possibilitando meu crescimento, não apenas profissional, como também pessoal.

MEUS MAIS SINCEROS AGRADECIMENTOS. 


\section{DEMAIS AGRADECIMENTOS}

Agradeço também,...

Aos professores do curso de Pós-Graduação da FOB, em especial aos docentes do Departamento de Saúde Coletiva, Prof. José Roberto de Magalhães Bastos, Prof. José Roberto Pereira Lauris, Profa. Nilce Emy Tomita e Profa. Silvia Helena de Carvalho Sales Peres, pelos importantes ensinamentos a mim dispensados.

Às funcionárias do Departamento de Saúde Coletiva da FOB, Helena, Marta, Rosa e Sílvia, pelo apoio e contribuição ao longo deste curso de mestrado.

Aos amigos da turma de mestrado em Saúde Coletiva, Agnes, Gustavo, Henrique, Ismar, Juliana, Melissa Thiemi, Ricardo Pianta, Rute, Sérgio, Suzana e Tatiane, por esta enriquecedora caminhada que passamos juntos.

Aos companheiros do Grupo de Odontologia Legal, César, Ricardo e Suzana, por toda colaboração e empenho no desenvolvimento de nossos projetos, além da constante determinação na busca pelo fortalecimento da Odontologia Legal em nosso meio.

Aos funcionários da biblioteca da FOB, pela preciosa colaboração.

A todos os cirurgiões-dentistas e discentes de odontologia que aceitaram participar desta pesquisa, foi a colaboração de todos vocês que tornou possível a realização deste trabalho. 


\section{SUMÁRIO}

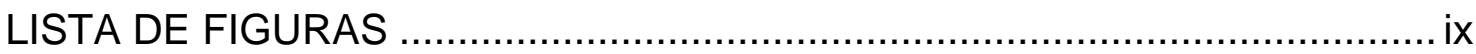

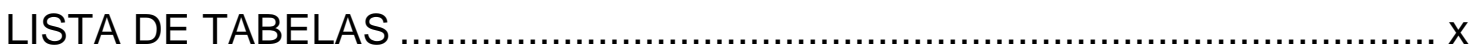

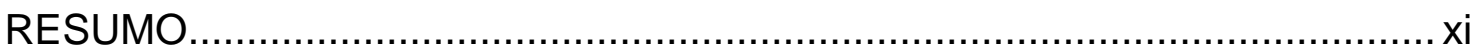

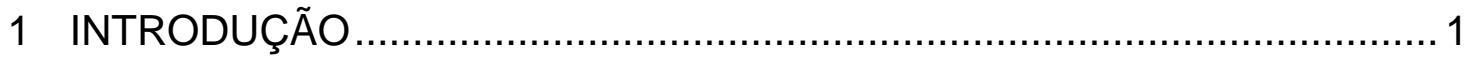

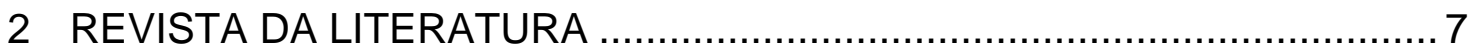

2.1 História da Odontologia no Brasil e no Mundo .................................. 8

2.2 Criação dos Conselhos de Odontologia........................................ 17

2.3 Ética, Bioética e Deontologia ................................................. 21

2.4 O Código de Ética Odontológica ............................................. 26

$2.5 \mathrm{O}$ ensino da ética aos profissionais na Odontologia ........................ 30

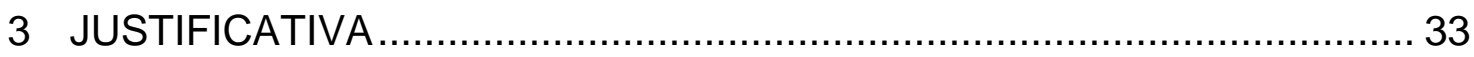

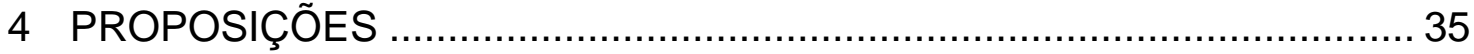

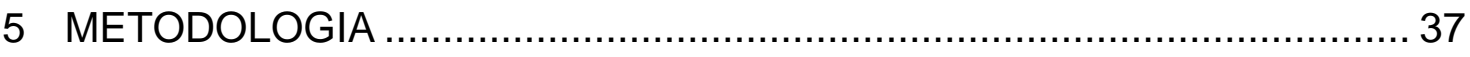

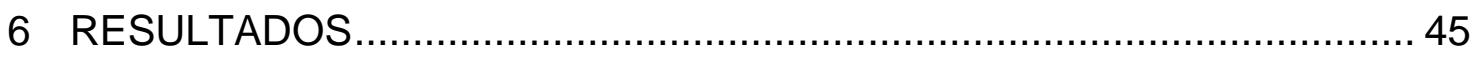

6.1 Caracterização das amostras ................................................ 46

6.2 Conhecimento do Código de Ética Odontológica............................ 50

6.3 Pontuação dos questionários, e comparação dos grupos................... 57

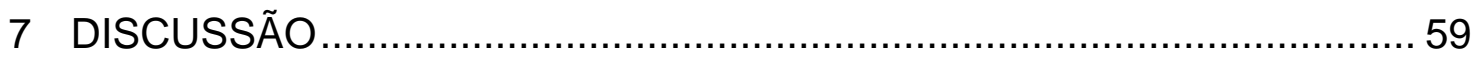

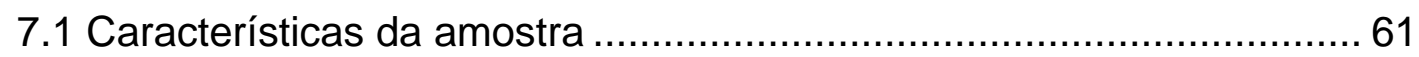

7.2 Conhecimento do Código de Ética Odontológica.............................63 63

7.2.1 Do anúncio, da propaganda e da publicidade.......................63 63

7.2.2 Do direito de renunciar ao atendimento do paciente................66 66

7.2.3 Do proprietário ou responsável técnico...............................69 69

7.2.4 Das infrações éticas........................................................ 71

7.2.5 Dos profissionais a quem se aplica o Código de Ética

Odontológica .............................................................. 72

7.3 Pontuação e comparação dos grupos......................................... 73

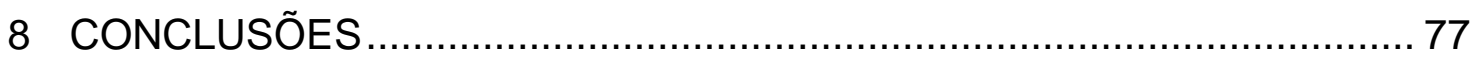

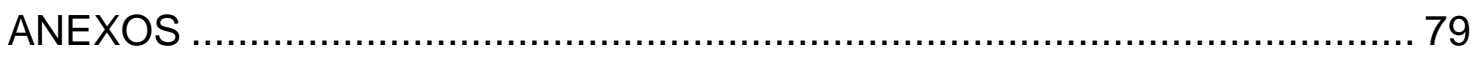

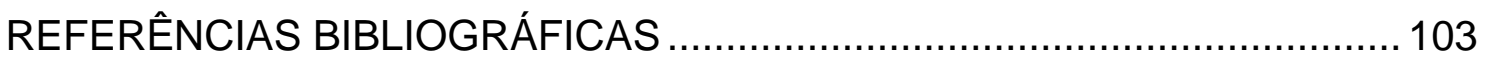

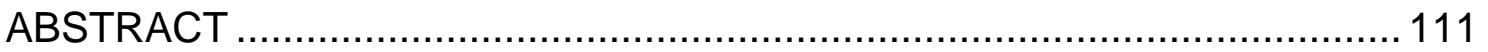




\section{LISTA DE FIGURAS}

FIGURA 6.1 - Representação gráfica segundo a faixa etária (I) e o tipo de instituição que freqüentam (II) os acadêmicos do último ano de graduação em Odontologia do município de Bauru-SP

FIGURA 6.2 - Representação gráfica segundo o tempo de formação (I), a faixa etária (II), o tipo de instituição que freqüentou (III) e a localização da faculdade (IV) dos cirurgiões-dentistas que atuam somente em consultório ou clínica no município de Bauru-SP

FIGURA 6.3 - Representação gráfica segundo o tempo de formação (I), a faixa etária (II), o tipo de instituição que freqüentou (III) e a localização da faculdade (IV) dos cirurgiões-dentistas que atuam em consultório ou clínica e cursam pós-graduação (especialização) em instituições no município de Bauru-SP

FIGURA 6.4 - Representação gráfica das respostas, separada por grupos, quando perguntado se o cirurgião-dentista tem direito de desistir do atendimento do paciente durante o tratamento

FIGURA 6.5 - Representação gráfica das respostas dos participantes que assinalaram "SIM" na questão anterior, quando perguntado em quais situações o cirurgião-dentista pode renunciar ao atendimento do paciente durante o tratamento

FIGURA 6.6 - Representação gráfica das respostas dos participantes, divididos em grupos, quando perguntado se o cirurgiãodentista inscrito no conselho, proprietário ou responsável técnico de clínica, responderia eticamente por erro de colega que atue sob sua responsabilidade

FIGURA 6.7 - Representação gráfica das respostas dos participantes, divididos em grupos, quando questionado sobre quais das opções constitui(em) infração(ões) ética(s), segundo o Código de Ética Odontológica

FIGURA 7.1 - Exemplos de propaganda irregular 


\section{LISTA DE TABELAS}

TABELA 6.1 - Número e porcentagem de respostas, separadas por grupo, referentes a quais informações devem constar obrigatoriamente nos anúncios, placas e impressos, segundo o Código de Ética Odontológica .............................................................

TABELA 6.2 - Número e porcentagem de respostas, separadas por grupo, referentes a quais profissionais se aplica o Código de Ética Odontológica 56

TABELA 6.3 - Mediana, média, desvio padrão, soma, valores mínimo e máximo, da pontuação dos questionários dos três grupos testados 58

TABELA 6.4 - Teste de Tukey, com nível de significância de 5\% $(p<0,05)$ 58 


\section{RESUMO}

O aumento no número de infrações éticas cometidas por cirurgiõesdentistas face ao descumprimento das normas do Código de Ética Odontológica (CEO), sugere que estes profissionais estão despreparados para enfrentar os dilemas éticos que surgem no dia a dia de sua profissão. Diante disso, propôs-se analisar o conhecimento de cirurgiões-dentistas e discentes em Odontologia, a respeito deste código deontológico, buscando ainda, verificar, se há diferença estatisticamente significante, quanto ao nível de conhecimento, entre os grupos: dos acadêmicos do último ano de graduação em Odontologia (GRUPO I), dos cirurgiões-dentistas que atuam exclusivamente em consultório ou clínica (GRUPO II), e dos cirurgiõesdentistas clínicos que cursam especialização (GRUPO III). Para isso, foram aplicados 150 questionários (50 para cada grupo), com questões objetivas que versavam sobre alguns dos principais artigos do CEO. Os resultados confirmaram que realmente existe deficiência no conhecimento de alguns aspectos éticos ligados a Odontologia, onde, dos 150 participantes, $n=90$ (60\%) não sabem que, além do cirurgião-dentista, todos os profissionais de outras categorias auxiliares reconhecidas pelo Conselho Federal de Odontologia, devem seguir as normas éticas do CEO. Outro resultado interessante, mostra que 31\% dos participantes, desconhecem que, em alguns casos, o cirurgião-dentista tem direito a renunciar ao atendimento do paciente durante o tratamento. O GRUPO II, quando comparado com os outros grupos, foi o que demonstrou uma maior deficiência no conhecimento das questões éticas que envolvem a Odontologia. Concluiu-se que é necessária uma maior divulgação possível do CEO, principalmente àqueles profissionais exclusivamente clínicos, com empenho máximo dos Conselhos de Odontologia, além dos docentes da área e as entidades de classe, buscando preventivamente educar e instruir, para evitar condenar e punir.

Palavras-chave: Ética Profissional. Ética Odontológica. Odontologia Legal. 


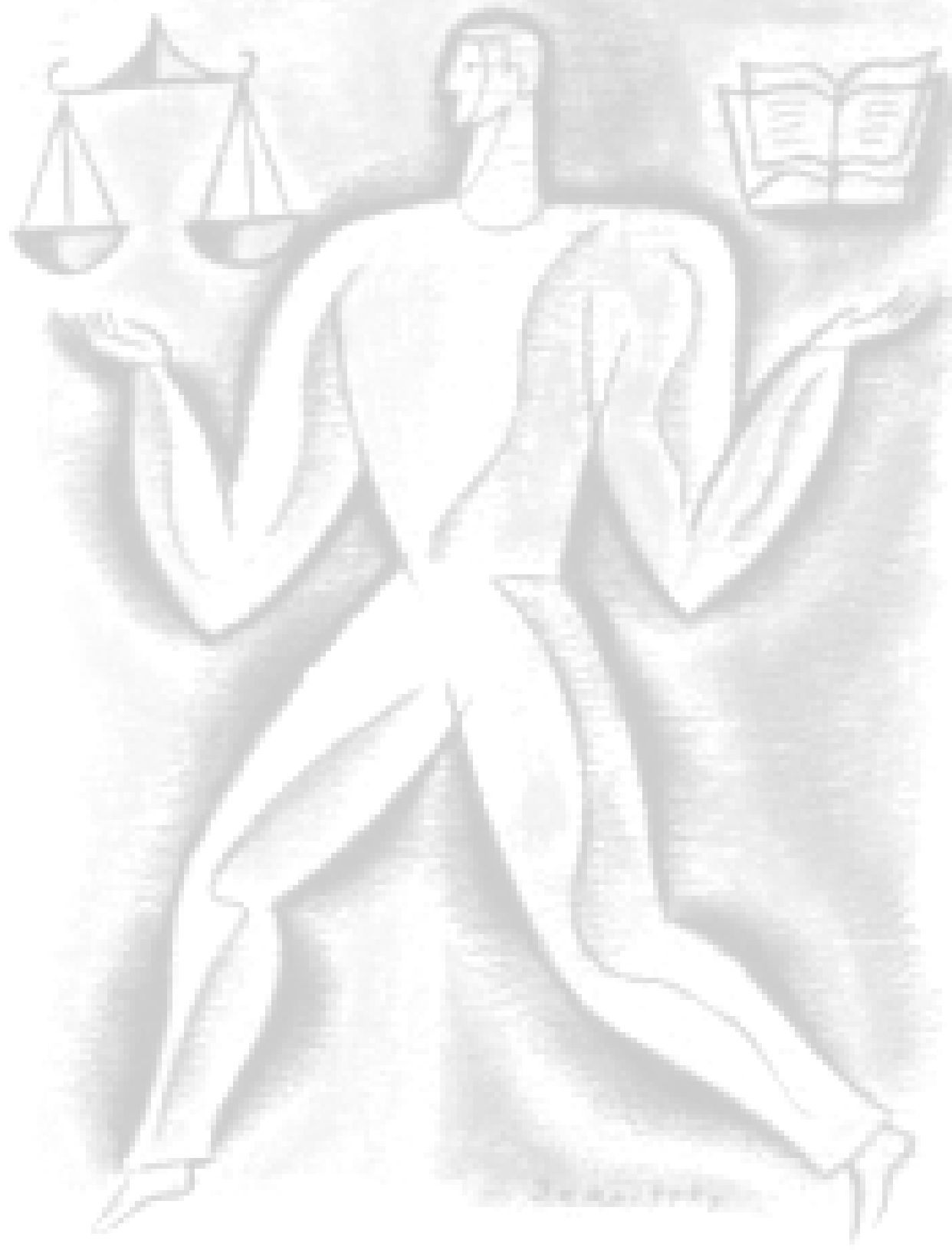

INTRODUÇÃO 


\section{INTRODUÇÃO}

A partir da década de 60, no Brasil, o desenvolvimento das Faculdades de Odontologia e a inserção de profissionais cirurgiões-dentistas na sociedade, fez com que este ofício necessitasse ser realizado de modo lícito e coerente.

Após a criação do Conselho Federal e dos Conselhos Regionais de Odontologia, através da Lei $n^{\circ} 4.324$, de 14 de abril de $1964^{5}$, a fiscalização do exercício da Odontologia passou para a competência desses órgãos, que apresentam como principal missão a supervisão da ética profissional odontológica em toda a República, zelando e trabalhando pelo seu perfeito desempenho no campo da Odontologia.

A ética profissional a ser supervisionada por estes Conselhos, refere-se ao conjunto de normas de conduta que deverão ser postas em prática no exercício da profissão, ou melhor, é o compromisso do homem exercer a sua profissão, respeitando o seu semelhante neste ofício que exerce.

A Odontologia é entendida como profissão liberal, ou seja, o cirurgiãodentista tem liberdade para decidir qual a melhor opção ou caminho a seguir, seja na fase do diagnóstico, do tratamento ou da proservação. Em face disto, um posicionamento ético indispensável é a responsabilidade, que se baseia na consciência que o homem deve ter de suas obrigações e deveres. Sem essa responsabilidade, o cirurgião-dentista não estará plenamente capacitado a exercer sua profissão como um profissional liberal.

Esta liberdade, por sua vez, deve estar fundamentada no cumprimento das normas que regulamentam os atos morais e não mais submetidos 
passivamente à tradição ou pelo temor aos castigos dos deuses ${ }^{25}$. Emergem daí com maior relevância os códigos que passam a orientar moralmente a vida e o trabalho nas sociedades humanas.

Com este intuito, formularam-se os vários Códigos de Ética, que norteiam e disciplinam a maneira correta de agir para cada profissão, facilitando a conduta humana dentro das diversas atividades profissionais, evitando certos abusos ${ }^{35}$.

Com este espírito de zelar e promover pelo bom conceito da profissão odontológica que os membros do Conselho Federal e dos Conselhos Regionais de Odontologia, elaboraram, em 1976, o primeiro Código de Ética Odontológica (CEO), estabelecendo os princípios fundamentais que direcionam a conduta do cirurgião-dentista no exercício da profissão ${ }^{36}$.

Ao longo do tempo, o Código de Ética Odontológica passou por algumas modificações, e hoje se encontra em sua quarta edição, que entrou em vigor a partir de 20 de maio de 2003, aprovado pela Resolução CFO-42/2003 ${ }^{14}$. Para LUCATO $^{29}$, 2005, tal instrumento (CEO) visa alcançar todos os cirurgiõesdentistas, técnicos em higiene dental, atendentes de consultório odontológico, técnicos em prótese dental e auxiliares de prótese dental, tentando fazer com que eles promovam a repersonalização de seus serviços.

Segundo SALES PERES et al. ${ }^{42}$, 2004, é importante salientar que, por principio, o Código de Ética Odontológica deve ser rotulado como um instrumento orientador, longe de vislumbrar um objetivo punitivo ao cirurgiãodentista, bem como, perseguir a consecução do bem comum dos pacientes, dos profissionais e da sociedade onde ambos se inserem. 
Portanto, o Código de Ética Odontológica tem com norma ética o sentido altamente pedagógico de evitar que se cometa atos antiéticos que poderão resultar em futuros prejuízos para o profissional e paciente ${ }^{45}$.

Entretanto, GAUDENZI ${ }^{25}$, em 2004, afirma que é importante reconhecer que os problemas éticos surgem no relacionamento pessoal ou nas relações de trabalho, provavelmente porque os valores morais dos profissionais não estão suficientemente interiorizados para que possam agir sempre da forma considerada eticamente correta.

Nessa perspectiva, a Lei $n^{\circ} 4.324$, de 14 de abril de $1964^{5}$, que instituiu o Conselho Federal e os Conselhos Regionais de Odontologia, cuidou de armar os mesmos com judiciosos éticos, seja no Conselho Federal como nos Conselhos Regionais, de forma a lhes possibilitar a execução de processos éticos, como julgadores técnicos, aceitando-se a forma contestatória e demais normas consagradas e admitidas no direito ${ }^{45}$.

Infelizmente, nos últimos anos, têm-se observado um substancial aumento no número de denúncias que chegam aos Conselhos Regionais de Odontologia, referente a infrações éticas cometidas por cirurgiões-dentistas. Estes problemas éticos tendem a crescer cada vez mais com 0 desenvolvimento tecnológico, com o avanço da ciência e coma democratização da informação em níveis globais, tanto para o profissional como para o paciente.

O grande número de Faculdades de Odontologia, a valorização da técnica em demasia e o distanciamento dos cursos da realidade social, promovem a formação de profissionais com uma visão humanista limitada. 
Além disso, a Odontologia vive um momento marcado por grandes dificuldades inerentes à oferta de trabalho.

Para SANTOS et al. ${ }^{46}, 2004$, tais situações direcionam o cirurgiãodentista para as armadilhas do mercantilismo profissional e, conseqüentemente, ao descumprimento das normas do Código de Ética Odontológica. Este profissional, na grande maioria das vezes, age de forma irregular por desconhecer os artigos do Código de Ética, ou não saber interpretá-los de forma correta.

Outrossim, após estas considerações, observou-se a necessidade de analisar o conhecimento de cirurgiões-dentistas e discentes em Odontologia, a respeito de alguns dos principais artigos contidos no Código de Ética Odontológica, buscando verificar se existe diferença estatisticamente significante, quando ao nível de conhecimento desse código deontológico, quando comparado os diferentes grupos: acadêmicos do último ano de graduação em Odontologia; cirurgiões-dentistas que atuam exclusivamente em consultório ou clínica; e cirurgiões-dentistas de atuação clinica que cursam especialização. 


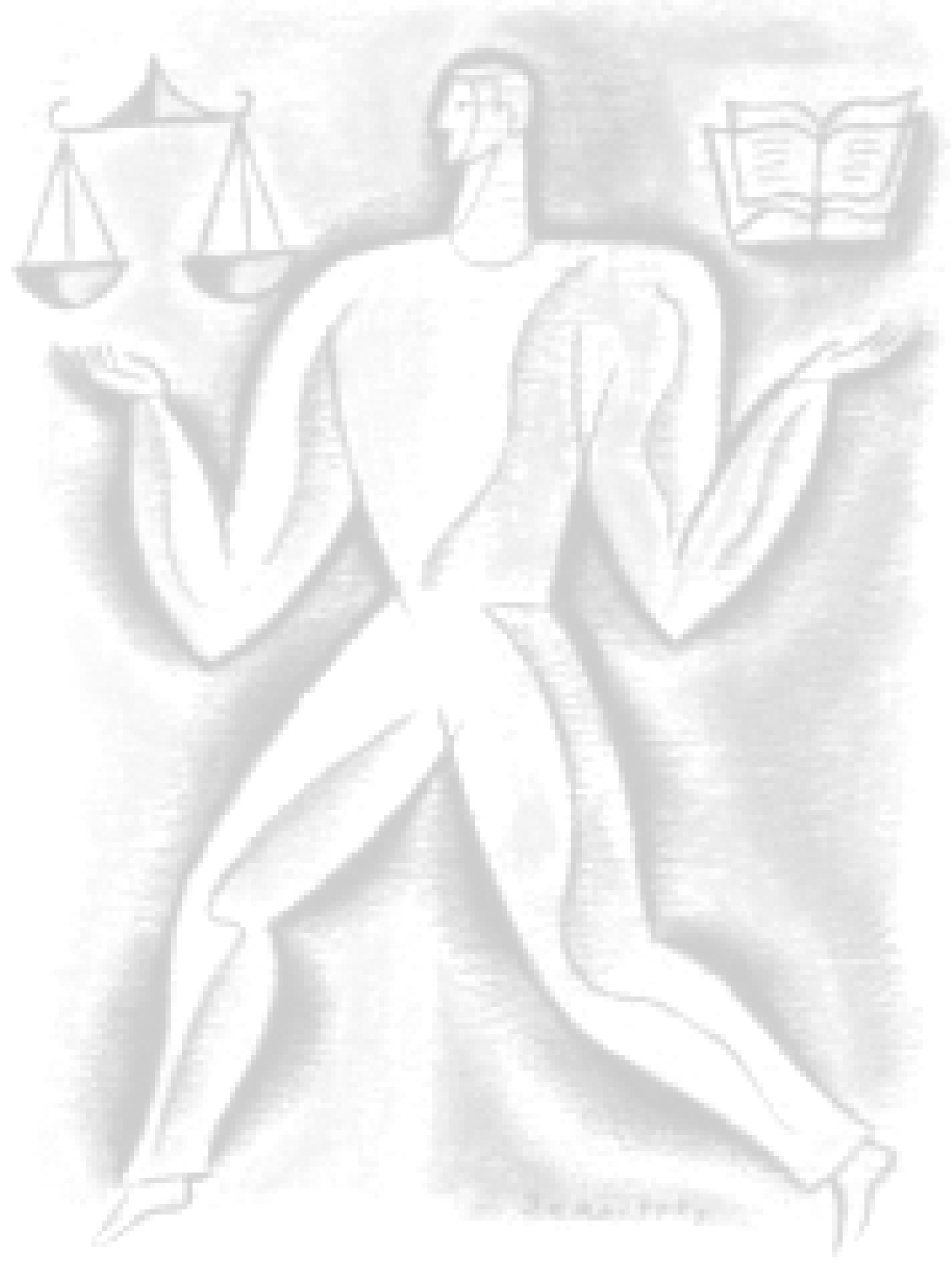

- 
REVISTA DA

LITERATURA 


\section{REVISTA DA LITERATURA}

Para RAMOS ${ }^{36}$, em 1997, os aspectos que envolvem a ética profissional odontológica são múltiplos e variados e, para se entender o contexto atual sobre o assunto, torna-se necessário fazer abordagens - histórica, sociológica e filosófica sobre o tema.

Para tanto, é importante que se faça uma análise do desenvolvimento da profissão odontológica, afirma LUCATO $^{29}$, em 2005, buscando facilitar o entendimento de sua evolução histórica no Brasil e no mundo, possibilitando a compreensão do atual posicionamento da profissão, bem como o entendimento de seus problemas.

\subsection{História da Odontologia no Brasil e no mundo}

A trajetória da Odontologia fez-se como um grande rio, nascendo na Mesopotâmia, chegando ao velho Egito e depois ao Mediterrâneo, atravessando-o ganhou à Grécia, inflectiu-se depois até Roma de onde seguiu para a Península Ibérica, chegou a França, Alemanha e Inglaterra e transpôs o Oceano Atlântico, espraiando-se pela América, sendo que nesse longo curso, foi recebendo afluentes importantes e lançando braços nas mais variadas direções, até chegar a excelência da atualidade ${ }^{17}$.

A Odontologia, denominada em seus primórdios como Arte Dentária, nasceu na Pré-História, porém seus registros mais antigos datam de 3500 a.C., 
na Mesopotâmia, onde é possível observar, nas inscrições da época, uma menção do que seria o verme responsável pela destruição da estrutura dentária, o gusano dentário ${ }^{41}$.

Nesta época onde se acreditava que vermes eram responsáveis pela destruição das estruturas dentárias, a civilização conhecia os mesmos processos cariosos e periodontais que sofremos hoje, sendo a religião e a magia os meios conhecidos para influenciar os deuses e assim evitar as enfermidades e restabelecer a saúde. Dessa forma, orações eram proferidas para destruir o verme responsável pela destruição do dente ${ }^{22}$.

FIGLIOLI $^{22}$, em 2001, relatou que esta lenda do verme causador da cárie evoluiu como verdade científica ao longo dos séculos, repetida e confirmada por diversos médicos e escritores.

Ainda a mesma autora, afirma que a Odontologia foi uma especialidade da medicina, tanto na doutrina quanto na prática. Dentro de uma incursão histórica aos primórdios da Odontologia, torna-se praticamente impossível estabelecer uma divisão concreta entre a Medicina e a Odontologia ${ }^{22}$.

Essa impossibilidade explica-se pelo fato de que na história das ciências médicas, tanto a Medicina, enquanto Ciência-Mater, quanto a Odontologia, que teve nela seus primórdios, nasceram em épocas pré-históricas, quando o homem primitivo teve suas primeiras dores ${ }^{1}$.

O primeiro dentista com nome conhecido foi Hesi-Re, este viveu no Egito e era considerado o "maior dos médicos que tratam dos dentes". Desta época, datam algumas evidências de que o tratamento odontológico estava separado do tratamento médico geral ${ }^{39}$. 
Já na Grécia são encontradas disseminadas entre os escritos Hipocráticos, numerosas referências aos dentes, sua formação e erupção, e as enfermidades da boca e dentes, além dos métodos de tratamento. Hipócrates acreditava que os problemas dentais eram provenientes de uma predisposição natural ou uma debilidade intrínseca. $\mathrm{E}$ em relação às pinças para extração de dentes disse que qualquer um poderia usa-las, pois era evidente a forma como deveriam ser utilizadas. Aparentemente toda a prática dental então existente era realizada pelo médico geral ${ }^{39}$.

RING ${ }^{39}$, em 1998, também escreve que a Odontologia era praticada em Roma, quando a profissão médica encontrava-se ainda na sua infância. Por volta de 450 a.C., os ricos costumavam enterra seus mortos com adornos de ouro, especialmente para unir dentes perdidos. A profissão médica em Roma era exercida por estrangeiros, escravos e escravos liberados. Também havia mulheres, que combinavam a medicina à magia. Mas a Odontologia não se encontra nessa época como profissão separada da medicina. São os trabalhos de Galeano que evidenciam a Odontologia como sendo praticada por médicos, que no início da prática de seu ofício, seguia os ensinamentos de Hipócrates de que o diagnóstico e plano de tratamento deviam ser precedidos necessariamente da observação e do estudo.

E assim permaneceu a Odontologia, atada aos conhecimentos médicos, e agregada ao ofício desenvolvido por esses profissionais, os médicos ou cirurgiões $^{22}$.

Durante os séculos XIII e XIV, as universidades medievais continuavam tomando por base antigos textos dos gregos e romanos. A dor de dente era, 
por isso, atribuída aos vermes dentais, e os dentistas a atacavam com mistura de alho poro com sebo de ovelha, e a aplicavam enquanto o paciente permanecia ajoelhado ou de pé junto a um braseiro onde a mistura era esquentada ${ }^{39}$

Com o decorrer dos tempos, a Odontologia entra em sua era précientífica, ampliando horizontes e possibilitando grandes perspectivas. Surgem as publicações, onde são exploradas questões sobre a Odontologia e sua relação com outras afecções, bem como o conhecimento do corpo humano através dos grandes anatomistas ${ }^{17}$.

E, dentro deste contexto, a Europa foi considerada o berço da Odontologia, onde surgiram os primeiros relatos desta ciência, a partir do século $X V I^{1}$.

O século XVIII introduziu mudanças profundas no exercício da Odontologia, impulsionadas pelos descobrimentos do século anterior. Por fim, a Odontologia se converteu em uma disciplina cientifica independente ${ }^{39}$.

Esta fase científica da Odontologia se apresenta com Pierre Fauchard, considerado o "Pai da Odontologia", iniciando sua carreira como cirurgião e dedicando-se, em seguida, integralmente a Odontologia, publicando uma obra notável, Le Chirugien Dentiste - Au Traité dês Dents ${ }^{17}$.

$\mathrm{E}$, finalmente, no século XIX, a Odontologia projeta-se, chegando à América, devido a três eventos importantes, todos nos Estados Unidos da América: a fundação da Society of Dental Surgeons em Nova York; a criação da primeira escola especializada na prática dental da América, a Escola de 
Odontologia de Baltimore; a publicação do primeiro jornal especializado, The American Jornal of Dental Science ${ }^{1}$.

No Brasil, com a vinda da primeira expedição colonizadora ao país, em 1530, e a instalação das Capitanias Hereditárias, surgiram os primeiros núcleos de povoação. Com isso, vieram os mestres de ofício de diversas profissões. Estes, recebiam licenciamento pela Carta Régia de 25/10/1448, do Rei Afonso $\mathrm{V}$ de Portugal. Entretanto, os cirurgiões que obtinham esta licença, como médicos, boticários e curandeiros, evitavam fazer extrações dentárias, restando aos barbeiros, sangradores e dentistas tal tarefa, sem a licença devida ${ }^{41}$.

ROSENTHAL ${ }^{41}$, em 2001, escreveu também que só em 09/11/1629, através da Carta Régia de Portugal, foi regularizado o exercício da arte dentária no Brasil, e pela primeira vez, citados os barbeiros, que poderiam, enfim, tirar dentes e promover sangria, se provassem aprendizagem de mais de dois anos.

Nas últimas décadas do século XVIII, Joaquim José da Silva Xavier (1746 - 1792) praticou a Odontologia que aprendera com seu padrinho. Nesta época o tratamento consistia em extrair dentes com alavancas e boticões rudimentares. Os mais habilidosos confeccionavam próteses parciais, esculpidas em marfim e ossos de boi, amarradas com fios aos dentes remanescentes ${ }^{41}$.

RING ${ }^{39}$, em 1998, relata que no século XIX os Estados Unidos assumem a vanguarda do desenvolvimento da Odontologia. No princípio deste século exerciam esta profissão os que se doutoravam a si mesmos, o médico local, alguns especialistas que faziam da Odontologia sua ocupação principal e 
dentistas ambulantes, que extraiam dentes, mas possuíam pouca ou nenhuma preparação profissional.

Muitos foram os progressos no século XIX. Dentre eles, a anestesia, a radiologia, a criação da American Dental Association, o equipamento dos gabinetes, o dique de borracha, materiais de restauração, entre outros ${ }^{39}$.

Segundo ROSENTHAL ${ }^{41}, 2001$, neste século, no Brasil, um exame que constava conhecimento parcial de anatomia e métodos operatórios e terapêuticos era requisitado ao candidato que tivesse interesse em exercer a profissão de dentista.

Em 1808 foram licenciados na Bahia profissionais da corte. Dado o pouco conhecimento ou inabilidade dos tiradentes, ocorriam graves e freqüentes traumatismos nos maxilares, com fraturas de dentes e alvéolos e dilaceração de tecidos $^{41}$.

Ainda o mesmo autor, relata que em 1869, muitos dentistas chegaram ao Brasil, vindos dos Estados Unidos, onde o desenvolvimento da profissão era destaque. Estes dentistas, que sabiam fazer incrustações a ouro, e possuíam sortimento de dentes de porcelana, atendiam a nobreza e famílias de grande poder econômico. Enquanto o povo e os escravos procuravam os barbeiros e sangradores $^{41}$.

A partir desse desenvolvimento tecnológico e cultural, começam a surgir os primeiros passos para se estabelecer a formação em Odontologia.

ROSENTHAL ${ }^{41}$, em 2001, escreve que em 1879, um decreto do governo brasileiro determinou que as Faculdades de Medicina deveriam anexar uma Escola de Farmácia, um curso de Obstetrícia e Ginecologia e um outro de 
Cirurgia Dentária. E a matricula, até então exclusiva aos homens, passou a ser direito das mulheres.

A partir de então ocorre a entrada na luta pela conquista do monopólio da intervenção na área bucal pelos diplomados, iniciada com a institucionalização dos cursos de Odontologia anexos às Faculdades de Medicina, pelo Decreto $\mathrm{n}^{\circ}$ 9.311, de 25 de outubro de 1884 , denominada Reforma Sabóia ${ }^{11}$.

CALVIELLI ${ }^{11}$, em 1993, ao realizar uma incursão histórica em sua dissertação de mestrado, constatou que os fatos históricos referentes à Odontologia tornam-se lacunosos após o século XIX, referindo-se, quase que exclusivamente, ao levantamento das legislações criadas.

A partir do século $X X$ ocorre um rápido avanço da ciência odontológica no Brasil, sendo criadas as primeiras Faculdades de Odontologia, porém ainda tendo a presença de "práticos" na profissão. Neste momento, legislações específicas são redigidas com 0 intuito de regularizar o exercício da Odontologia, impedindo a formação de novos "práticos" 11.

CALVIELLI $^{10}$, em 1997, relata que em 04 de dezembro de 1933 foi expedido o Decreto $n^{\circ}$ 23.540, o qual fixava a data de 30 de junho de 1934 como a data limite para concessão de licença aos práticos em exercício, denotando as primeiras medidas efetivas para a monopolização do exercício da Odontologia pelos portadores de diploma de curso superior.

Sendo assim surge, finalmente, a primeira regulamentação do exercício profissional da Odontologia através da Lei no 1.314 , de 17 de janeiro de $1951^{4}$. 
"Art. 10. - O exercício da profissão de odontologista no território nacional só será permitida aos que se acharem habilitados por título obtido em Escola de Odontologia, oficialmente ou legalmente reconhecida, devidamente registrado na Diretoria do Ensino Superior e anotado, sucessivamente, no Serviço Nacional de Fiscalização da Medicina e na repartição sanitária estadual competente."

Bem como as instruções reguladoras pela Portaria $n^{\circ} 101$, de 28 de junho de $1951^{8}$.

"O Diretor Geral do Departamento Nacional de Saúde, no uso de suas atribuições legais, resolve aprovar as instruções anexas que regulamentam a Lei $n^{\circ} 1.314$ de 17 de janeiro de 1951, de conformidade com o artigo 18 da referida lei"

Em 1954, criam-se, no Brasil, os Exames para Dentistas e Sangradores, aplicados a partir de 1956. Para obter o título de dentista, o candidato fazia exames na Faculdade de Medicina da Bahia ou do Rio de Janeiro ${ }^{41}$.

A publicidade dos dentistas, desenvolvimento ocorrido na década de 60, mudou o caráter e a imagem da profissão. Muitos dos dentistas que usaram a publicidade, montaram seus consultórios em salas de edifícios ou centros comerciais, oferecendo à classe trabalhadora acesso a serviços depois do trabalho, nos fins de semana ou durante as férias. Embora a publicidade tenha estimulado o paciente a escolher seu dentista em função do preço ou honorários, e não em função da melhor preparação do dentista escolhido, também ajudou a colocar a assistência odontológica ao alcance de um número muito maior de pessoas ${ }^{39}$. 
Também nesta época surgiu a existência de uma nova modalidade de pagamento, através de terceiros. Estes, geralmente grupos de seguradores que por uma taxa se encarregam de pagar assistência odontológica básica de rotina e, em alguns casos, a odontologia mais completa (convênios). Em alguns países da Europa, nesta mesma época, existia um tipo de seguro financiado pelo governo ${ }^{39}$.

É nesse momento cultural, quem no Brasil, o desenvolvimento das Faculdades de Odontologia e a inserção de profissionais na sociedade, faz com que este ofício passe a ser realizado de modo legal e coerente ${ }^{41}$.

A próxima etapa da evolução profissional foi a instituição do Conselho Federal e dos Conselhos Regionais de Odontologia, através da Lei $n^{0} 4.324$, em 14 de abril de $1964^{5}$.

Após tantas turbulências na conformação profissional da Odontologia, a classe recebe em 24 de agosto de 1966 a Lei $n^{0} 5.081^{6}$, que regulamenta 0 exercício da Odontologia em todo território nacional e vem para substituir a Lei $\mathrm{n}^{0} 1.314$ de 17 de janeiro de 1951.

Então, para MEIRA ${ }^{32}$, em 1994, a Odontologia passa a ser, definitivamente, uma profissão, isto é, uma atividade especializada, de caráter permanente, em que se desdobra o trabalho total realizado em uma sociedade.

A partir de então se observa um rápido crescimento da profissão, exemplificado pela abertura de inúmeros cursos de graduação e pósgraduação, bem como um grande salto científico e tecnológico. 


\subsection{Criação dos Conselhos de Odontologia}

De relevância para o tema, merecendo um capitulo a parte, o principal fato histórico seria a criação do Conselho Federal e dos Conselhos Regionais de Odontologia.

O Conselho Federal de Odontologia e os Conselhos Regionais foram criados através da Lei $n^{\circ} 4.324$, de 14 de abril de 1964, modificada pela Lei $n^{\circ}$ 5.965, de 10 de dezembro de 1973 , tendo aquela sido regulamentada pelo Decreto $n^{0} 68.704$, de 03 de junho de $1971^{45}$.

São constituídos em seu conjunto, como uma Autarquia, tendo cada um deles personalidade jurídica de direito público, com autonomia administrativa e financeira. Têm as missões e encargos de cuidar da ética profissional em toda a República, zelando e trabalhando pelo seu perfeito desempenho no campo da Odontologia, pelo prestígio e bom conceito da profissão, notadamente do exercício profissional dos que a exercem legalmente, inclusive dos que praticam profissões auxiliares, sendo todos inscritos e registrados num Conselho Regional e no Conselho Federal de Odontologia ${ }^{5}$.

Para SAMICO ${ }^{45}$, em 1990, destarte, a par com suas específicas funções de natureza ética, os Conselhos de Odontologia exercitam atividades inerentes ao Estado no controle do exercício profissional, para cuja ação e êxito foram pela lei lhe conferidas todas as garantias.

O Conselho Federal, segundo o artigo 4 da Lei $n^{\circ} 4.324$ de 14/04/1964 ${ }^{5}$, tem como atribuições: 
“a) organizar o seu regimento interno;

b) aprovar os regimentos internos organizados pelos Conselhos Regionais;

c) eleger o presidente e o secretário-geral do Conselho;

d) votar e alterar o Código de Deontologia Odontológica, ouvidos os Conselhos Regionais;

e) promover quaisquer diligências ou verificações relativas ao funcionamento dos Conselhos de Odontologia, nos Estados ou Territórios e Distrito Federal, e adotar, quando necessário, providências convenientes à bem da sua eficiência e g) regularidade, inclusive a designação de diretoria provisória;

f) propor ao Governo Federal a emenda ou alteração do Regulamento desta Lei;

g) expedir as instruções necessárias ao bom funcionamento dos Conselhos Regionais;

h) tomar conhecimento de quaisquer dúvidas suscitadas pelos Conselhos Regionais e dirimi-las;

i) em grau de recursos por provocação dos Conselhos Regionais ou de qualquer interessado, deliberar sobre admissão de membros aos Conselhos Regionais e sobre penalidades impostas aos mesmos pelos referidos Conselhos;

j) proclamar os resultados das eleições, para os membros dos Conselhos Regionais e do Conselho Federal a terem exercício no triênio subseqüente;

l) aplicar aos membros dos Conselhos Regionais, e aos próprios, as penalidades que couberem pelas faltas praticadas no exercício de seu mandato;

m) aprovar o orçamento anual próprio e dos Conselhos Regionais;

n) aprovar, anualmente, as contas próprias e as dos Conselhos Regionais."

Tendo a incumbência de disciplinar e, até mesmo, de certo modo, gerir a organização de atividades profissionais de saúde no âmbito da Odontologia, o 
Conselho Federal e os Conselhos Regionais se instituem como órgãos coordenadores e, quando preciso, também disciplinadores, em nome do Estado que Ihes delegou poderes para tanto, quando conferiu a eles, como órgãos profissionais, o poder de gerir a profissão ${ }^{45}$.

Aos Conselhos Regionais, segundo o artigo 11 da Lei $\mathrm{n}^{0} 4.324$ de 14/04/1964 ${ }^{5}$, compete:

“a) deliberar sobre inscrição e cancelamento, em seus quadros de profissionais registrados na forma desta lei;

b) fiscalizar o exercício da profissão, em harmonia com os órgãos sanitários competentes;

c) deliberar sobre assuntos atinentes à ética profissional, impondo a seus infratores as devidas penalidades;

d) organizar o seu regimento interno, submetendo-o à aprovação do Conselho Federal;

e) sugerir ao Conselho Federal as medidas necessárias à regularidade dos serviços e à fiscalização do exercício profissional;

f) eleger um delegado-eleitor para assembléia;

g) dirimir dúvidas relativas à competência e âmbito das atividades profissionais, com recurso suspensivo para o Conselho Federal;

h) expedir carteiras profissionais;

i) promover por todos os meios ao seu alcance o perfeito desempenho técnico e moral de odontologia, da profissão e dos que a exerçam;

j) publicar relatórios anuais de seus trabalhos e a relação dos profissionais registrados;

k) exercer os atos de jurisdição que por lei Ihes sejam cometidos;

l) designar um representante em cada município de sua jurisdição; 
m) submeter à aprovação do Conselho Federal o orçamento e as contas anuais."

$\mathrm{Na}$ opinião de $\mathrm{SAMICO}^{45}$, em 1990, para o exercício de tais missões entendeu o legislador pátrio, muito bem avisado aliás, que os Conselhos Profissionais teriam melhores possibilidades de êxito se fossem, como são, órgãos eminentemente éticos. Isto porque normatizando o comportamento moral dos profissionais que Ihes são obrigatoriamente filiados e por eles fiscalizados, promovem o bem comum. Na verdade, cumpridas normas éticas de conduta profissional ter-se-a uma boa prática de atos na profissão e, assim, raros casos restariam para ações judiciárias. Na opinião dos autores, certamente seriam em muito menor quantidade as infrações cometidas, restando muito pequena, a necessidade de exercitar-se o poder coercitivo no âmbito da Justiça Criminal e, seguramente, menor seria o número de pacientes que se julgariam prejudicados, recorrendo a ações cíveis no campo do Direito Privado.

Vale ser desde logo aludido, como inovação salutar do direito nacional, que as leis que instituíram os Conselhos Profissionais ${ }^{5}$, cuidaram de armar os mesmos com judiciosos éticos, seja no Conselho Federal como nos Conselhos Regionais, de forma a lhes possibilitar a execução de processos éticos, como julgadores técnicos, aceitando-se a forma contestatória e demais normas consagradas e admitidas no direito.

A titulo de exemplo, o Art. $3^{\circ}$ do Código de Processo Ético Odontológico, na edição aprovada pela Resolução CFO-59/2004 de 06 de outubro de $2004^{15}$, traz: 
"O sistema processual ético dos Conselhos de Odontologia se divide em duas instâncias, sendo a primeira constituída pelos Conselhos Regionais e a segunda e última representada pelo Conselho Federal".

A par com a majestade da profissão odontológica agigantam-se como meios orientadores e disciplinadores, as funções dos Conselhos de Odontologia. Daí a necessidade de se buscar difundir normas éticas de comportamento profissional que, decerto, além de dignificarem a profissão e seus integrantes, contribuíram para melhor situar a conduta moral exigida e deste modo evitar infrações ou erros que prejudiquem a classe, o profissional, o paciente e a sociedade ${ }^{45}$.

\section{3 Ética, Bioética e Deontologia}

Para facilitar o entendimento do assunto, segundo AMORIM², em 2005, torna-se de fundamental importância, conceituarmos ética, bioética e deontologia, abordando em separado cada um desse temas, com a finalidade de esclarecer, de maneira clara e objetiva, o valor destes termos dentro das profissões da saúde, em especial da Odontologia.

Ética vem do grego "ethike" que significa modo de ser ou caráter, ou seja, é conjunto de valores que orientam o comportamento do homem em relação aos outros homens na sociedade em que vivem, garantindo, outrossim, 
o bem estar social. Por isso, a ética é hoje considerada uma ciência social, deixando de ser uma parte da filosofia, como a anos foi considerada ${ }^{34}$.

Segundo FERREIRA ${ }^{21}$, em 1987, a ética é o estudo do juízo de apreciação que se refere à conduta humana suscetível de qualificação do ponto de vista do bem e do mal, seja relativamente à determinada sociedade, seja de modo absoluto.

Já para VÁSQUEZ ${ }^{50}$, 1975, a ética é a teoria ou ciência do comportamento moral dos homens em sociedade.

Tomando as diferentes definições de ética, faz-se necessário partir para uma definição também de moral:

Para FERREIRA ${ }^{21}$, em 1987, moral é o conjunto de regras de conduta consideradas como válidas, quer de modo absoluto para qualquer tempo ou lugar, quer para grupo ou pessoa determinada.

E segundo VÁSQUEZ ${ }^{50}$, em 1975, moral é um sistema de normas, princípios e valores, segundo o qual são regulamentadas as relações mútuas entre os indivíduos ou entre estes e a comunidade, de tal maneira que estas normas, dotadas de um caráter histórico e social, sejam acatadas livres e conscientemente, por uma convicção íntima e não de uma maneira mecânica, externa ou impessoal.

Segundo RIOS ${ }^{40}, 1995$, vemos, no cotidiano, que os conceitos de ética e de moral se confundem ou se identificam e que isso tem uma certa razão. $O$ ethos, enquanto é a casa do homem, o espaço do ethos, enquanto espaço humano, não é dado ao homem, mas por ele construído ou incessantemente reconstruído. O domínio do ethos é o da moralidade, do estabelecimento de 
deveres, a partir da reiteração das ações e da significação a elas atribuídas. "O ethos é a face da cultura que se volta para o horizonte do dever-ser ou do bem"51.

Para GOMES ${ }^{27}$, em 1996, a ética constitui-se no principio e fim da própria vida, na medida em que se torna o próprio sentido da existência, a razão essencial de ser e haver, o motivo pelo qual a existência se relaciona com o todo, pelo qual se transforma e por sua vez transforma o próprio meio como agente e sujeito dessa mudança.

Portanto, estudar a ética é formar o embasamento para o comportamento moral que se faz imprescindível ao exercício profissional, mormente em profissões que lidam com a saúde, mais especificamente com o ser humano ${ }^{18}$.

Já o termo bioética surgiu em 1971, tratando-se, segundo URBAN ${ }^{48}$, em 2003, de um neologismo, apenas recentemente incorporado aos dicionários de língua portuguesa.

O vocábulo bioética popularizou-se, segundo $\mathrm{AMORIM}^{2}, 2005$, a partir do biólogo e oncologista Van Renssealer Potter, que publicou o livro Bioethics: a bridge to the future. Potter disse:

“Escolho 'bio' para representar o conhecimento biológico dos sistemas viventes e escolho 'ética' para representar o conhecimento dos sistemas dos valores humanos". 
Sua proposta era a de estabelecer uma "ponte" entre ciências biológicas e valores morais, em vista de fundar uma nova ética baseada no escopo da sobrevivência humana num ambiente saudável.

Este novo termo, não tinha o objetivo de repetir o que já existia na área médica, mas abranger todo o inter-relacionamento com as diferentes formas de vida que em última análise afeta profunda e decisivamente o ser humano ${ }^{18}$.

Para ZANCAN ${ }^{52}$, em 1999, bioética significa a ética da vida, surgindo numa época de questionamentos quanto aos vínculos (possíveis e/ou necessários) entre ética, ciência e política na resolução de "novos" problemas que surgiam no campo da medicina e da saúde pública, decorrentes das transformações tecnológicas e sociais vivenciadas, sobretudo a partir da segunda metade do século $X X$.

Em conformidade com BARCHIFONTAINE e PESSINI ${ }^{3}$, em 1996, a bioética possui como características principais o fato de ser protetora da vida frente às inovações tecnológicas, tratar o homem como sujeito e não como objeto, ter caráter transdisciplinar e buscar a humanização das ciências da saúde.

Outro aspecto importante da bioética é que ela não se encontra restrita às Ciências da Saúde. Desde que surgiu, o seu olhar está direcionado para a vida e conseqüentemente, para todas as áreas do conhecimento que, de uma forma ou de outra, tem implicações sobre a vida de todos nós. Por essa razão, nas sociedades constituídas para os estudos da Bioética e nos congressos, não há apenas médicos, dentistas, enfermeiros ou profissionais das áreas de 
saúde. Encontramos também, juristas, filósofos, sociólogos, psicólogos, teólogos, economistas, entre outros ${ }^{19}$.

O termo bioética expressa, segundo MARQUES ${ }^{31}, 1996$, em sua complexidade, muito mais um conjunto de vozes do que uma disciplina específica.

Para VASCONCELLOS ${ }^{49}$, em 2003, a grande tarefa da bioética é fornecer meios para se chegar a uma escolha racional frente à disparidade existente entre opiniões morais referentes à vida, saúde e morte, em situações especiais, devendo essa determinação ser dialogada, compartilhada e decidida entre pessoas com valores morais diferentes em sociedades plurais.

Completando as definições de termos relacionados ao tema, vejamos deontologia.

A deontologia, palavra derivada do grego, Deontos - significa dever juntamente com logus - estudo. Para FERREIRA ${ }^{21}$, 1987, deontologia é o estudo dos princípios, fundamentos e sistemas de moral; tratado de deveres. E VÁSQUEZ ${ }^{50}$, em 1975, define deontologia como a teoria da obrigação moral quando não se faz depender a obrigatoriedade de uma ação exclusivamente das conseqüências da própria ação ou da norma com a qual se conforma.

A deontologia é o conjunto codificado das obrigações impostas aos profissionais de uma determinada área, no exercício de sua profissão. São normas estabelecidas pelos próprios profissionais, tendo em vista não exatamente a qualidade moral de suas ações, mas a "correção" das mesmas, tendo em vista a relação entre profissão e sociedade ${ }^{18}$. 
Para SEGRE ${ }^{47}$, em 2002, podemos chamar a deontologia odontológica de moral odontológica, isto é, o elenco das obrigações que o odontólogo tem, porque assumiu, com o seu "mundo profissional": o paciente, a família do paciente, a sociedade em geral, o colega, o Estado. A deontologia cabe a conceituação para o exercício profissional dentro de qualquer área da saúde, será uma questão de "dever ser", e não de "ser", de acordo com a postura ética individual, internamente assumida e progressivamente amadurecida.

\subsection{O Código de Ética Odontológica}

$\mathrm{RAMOS}^{36}$, em 1997, afirma que os principais referenciais para análise da ética odontológica são os códigos de ética odontológica. O autor justifica, dizendo que estes documentos abordaram as questões do relacionamento do profissional com seu paciente e dos profissionais entre si, temas que suscitaram os maiores debates dentro da classe odontológica.

Como já foi visto, a ética é a ciência do comportamento humano em relação aos valores, aos princípios e às normas morais. E a deontologia é um complexo de obrigações e deveres que deve nortear a ação humana em todas as suas manifestações.

Já a definição de "código", segundo GOMES²6, em 2003, é - "todo conjunto de regras, preceitos ou prescrições, que em sentido jurídico se caracteriza por ser um corpo de leis, com normas que disciplinam determinada 
matéria, dispostas em um todo orgânico, de forma a facilitar a consulta, aplicação e interpretação".

O primeiro código de deontologia foi feito exatamente na área médica, nos Estados Unidos, em meados do século $\mathrm{XIX}^{18}$.

Os códigos de ética vão buscar os seus princípios de conduta condicionados ao bem estar social, com a integração entre a classe profissional e a sociedade. Nenhuma profissão se esgota na prática dos atos profissionais. Os seus reflexos se dão em outras esferas legais e a legislação deve estar erigida em harmonia com elas ${ }^{9}$.

Para D'ASSUMPÇÃO ${ }^{18}$, em 1998, as bases dos códigos de ética surgiram como resultado de um trabalho de grupo totalmente embasado no exercício continuado da consciência crítica, característica pertencente só ao homem, utilizada para estabelecer regras independentemente de uma experiência pessoal. Esta "consciência crítica", por sua vez, torna-se mais eficaz, através da utilização do método "VER-JULGAR-AGIR-REVER", introduzido pelo cardeal belga Cardjn, na década de 30.

Para o autor, os códigos de ética são o resultado deste trabalho do VERJULGAR-AGIR-REVER, executado por grupos de profissionais voltados para as necessidades éticas de cada tipo de atividade.

Segundo MUYLAERT ${ }^{35}$, em 1977, buscou-se elaborar os vários códigos de ética, para facilitar a conduta humana dentro das atividades profissionais e evitar certos abusos, norteando e disciplinando a maneira correta de agir em cada profissão. 
E foi com esse espírito de zelar e promover o bom conceito da profissão odontológica que os membros do Conselho Federal e dos Conselhos Regionais de Odontologia elaboraram o Código de Ética Odontológica, que estabelece os princípios fundamentais que direcionam a conduta do cirurgião-dentista no exercício da profissão ${ }^{36}$.

O Código de Ética Odontológica possui algumas versões. Entre as primeiras, está a Resolução CFO - 102/76, publicada em 1976, e vigorou até 31 de dezembro de 1983. Como atualização desta primeira, se encontra a Resolução CFO - 151/83, que vigorou de $1^{\circ}$ de janeiro de 1984 até 31 de dezembro de 1991. Segundo RAMOS ${ }^{36}$, 1997, estes dois primeiros institutos éticos foram elaborados por comissões instituídas pelo Conselho Federal de Odontologia (CFO) com a finalidade de elaborar um anteprojeto de Código de Ética, após ouvir alguns segmentos da classe odontológica.

RAMOS $^{37}$, em 1994, relata, que no início de 1991 o CFO deflagrou um processo em nível nacional, instruindo os Conselhos Regionais de Odontologia a promoverem conferências estaduais para que a classe odontológica pudesse manifestar seus anseios quanto ao Código de Ética Odontológica (CEO) que vigorava desde 1983, instituído pela Resolução CFO - 151/83. As conclusões dessas conferências estaduais foram levadas à I Conferência Nacional de Ética Odontológica - CONEO por cerca de 400 delegados de diferentes regiões e realidades do país. Pelo método de consenso em grupos de trabalho e assembléias, buscou-se equacionar aspectos práticos da vida profissional: relacionamento profissional-paciente, profissional-equipe de saúde, profissional-sociedade, etc. E assim, pelo método democrático, se originou um 
documento final, síntese dos trabalhos realizados nesta conferência. 0 Relatório Final da I CONEO foi posteriormente acatado pelo Conselho Federal, na íntegra, como o novo Código de Ética Odontológica, através da Resolução CFO - 179/91 de 19 de dezembro de $1991^{13}$.

A III Conferência Nacional de Ética Odontológica foi realizada em Florianópolis, de 11 a 14 de dezembro de 2002. O objetivo desse evento foi o debate amplo e participativo de toda a classe odontológica brasileira para reformulação do Código de Ética Odontológica, adequando-o às transformações sociais e profissionais determinadas pelo momento histórico. As conclusões da III CONEO constituíram a base sobre a qual foi redigido o novo Código de Ética Odontológica, que está em vigor desde o início de 2003, através da Resolução CFO - 42/2003 ${ }^{14}$.

Esta Resolução esta mais próxima, portanto, do momento cultural que vivenciamos na odontologia hoje, trazendo modificações, como por exemplo, a questão da propaganda, que recebeu diversas alterações. Isto porque, como relata RAMOS ${ }^{36}$, em 1997, nesses códigos, elaborados pelos profissionais para profissionais, sempre se preocupa descaracterizar a odontologia como uma profissão voltada para o lucro, condenando posturas mercantilistas frisando a responsabilidade dos profissionais para com a saúde de seu paciente e da coletividade, como princípio fundamental da profissão, procurando coibir qualquer forma de desrespeito a ele.

Recentemente o capítulo XIV do Código de Ética Odontológica, que trata da comunicação em odontologia, sofreu uma leve modificação na parte que trata da publicidade e propaganda odontológica. A alteração no texto foi votada 
em um fórum realizado em Recife, no Conselho Regional de Odontologia de Pernambuco, com o nome de: "Fórum Nacional de Discussão do Capítulo de Propaganda e Publicidade do Código de Ética Odontológica", realizada nos dias 06 e 07 de abril.

A nova redação alterando o texto do capítulo XIV foi aprovada através da Resolução CFO - 71, de 06 de junho de 2006, na CCIX Reunião Ordinária, de 25 de maio de 2006, que referendou as decisões de CCVII Reunião Ordinária do Plenário do Conselho Federal de Odontologia - Assembléia Conjunta com os Conselhos Regionais de Odontologia, em Recife, nos dias 06 e 07 de abril de $2006^{16}$.

\section{5 ensino da ética aos profissionais na odontologia}

Não há registro histórico adequado disponível do surgimento do ensino da ética nos cursos de saúde nacionais. Sabe-se que já nos primórdios do século $\mathrm{XX}$, a Medicina Legal era ministrada e estudada por figuras como Flamínio Fávero Gomes ${ }^{24}$.

GOMES $^{27}$, em 1996, considera, que da mesma forma que na educação social, o período da infância e juventude são considerados críticos para formação de hábitos e modelagem da personalidade, por analogia, a formação ética do profissional de saúde deveria ser iniciada nas disciplinas básicas do estágio pré-clínico com noções mais gerais de ética, e um curso teórico e substantivo de bioética. 
O ensino de questões deontológicas, feito na disciplina de Odontologia Legal e Deontologia, tem um caráter sistemático. Isto todavia não impede que tais questões sejam sempre referidas no ensino teórico e, sobretudo, prático, de outras disciplinas. Impõe-se até que assim seja feito porque na graduação, como um todo, busca-se obter uma formação global, cultural e ética, concomitantemente com o processo ensino-aprendizagem técnico-científico. Cuida-se desde logo de formar um profissional completo, integral e cônscio de sua responsabilidade social e dos reclamos da comunidade científica, para que no futuro, quando no exercício legal da profissão odontológica, possa cumprir seus deveres e defender seus direitos ${ }^{44}$.

Os argumentos acima, estão presentes, por exemplo, por vários momentos, nas Diretrizes Curriculares Nacionais dos Cursos de Graduação em Farmácia e Odontologia, aprovadas pelo Parecer CNE/CES n 1300, em 06 de novembro de $2001^{7}$, onde encontram-se algumas das características desejáveis nos futuros profissionais de saúde, como por exemplo:

Os profissionais devem realizar seus serviços dentro dos mais altos padrões de qualidade e dos princípios da ética/bioética, tendo em conta que a responsabilidade da atenção à saúde não se encerra com o ato técnico, mas sim, com a resolução do problema de saúde, tanto em nível individual como coletivo;"

atitudes e valores correspondentes à ética profissional e ao compromisso com a sociedade." 
Entretanto, a carga horária, reservada ao ensino da ética nos cursos de graduação em odontologia, tem-se mostrado insuficiente. Segundo GARBIN et al. ${ }^{24}$, em 2002, um maior número de horas-aula, e melhor distribuição desse assunto ao longo do curso, ajudaria no preparo ético dos novos profissionais.

Para GOMES ${ }^{27}$, em 1996, o ensino da ética para profissionais da saúde, em qualquer estágio de formação profissional, não deve limitar-se à aula expositiva, mas sim conduzir-se de forma dinâmica, com discussão de casos concretos e participação ativa dos estudantes, assim como dos profissionais já formados.

Apesar de todo profissional de saúde contar com um código de ética, formalmente instituído, esse profissional não pode se prender apenas a este código deontológico ou a outros regulamentos formais para respeitar o paciente ou o cidadão. É necessário, segundo GAUDENZI ${ }^{25}$, em 2004, ir além do código, mas isso não tem como estar escrito, pois se espera que ele esteja inserido na consciência moral de cada profissional, ao fazer o melhor uso possível de sua liberdade. 


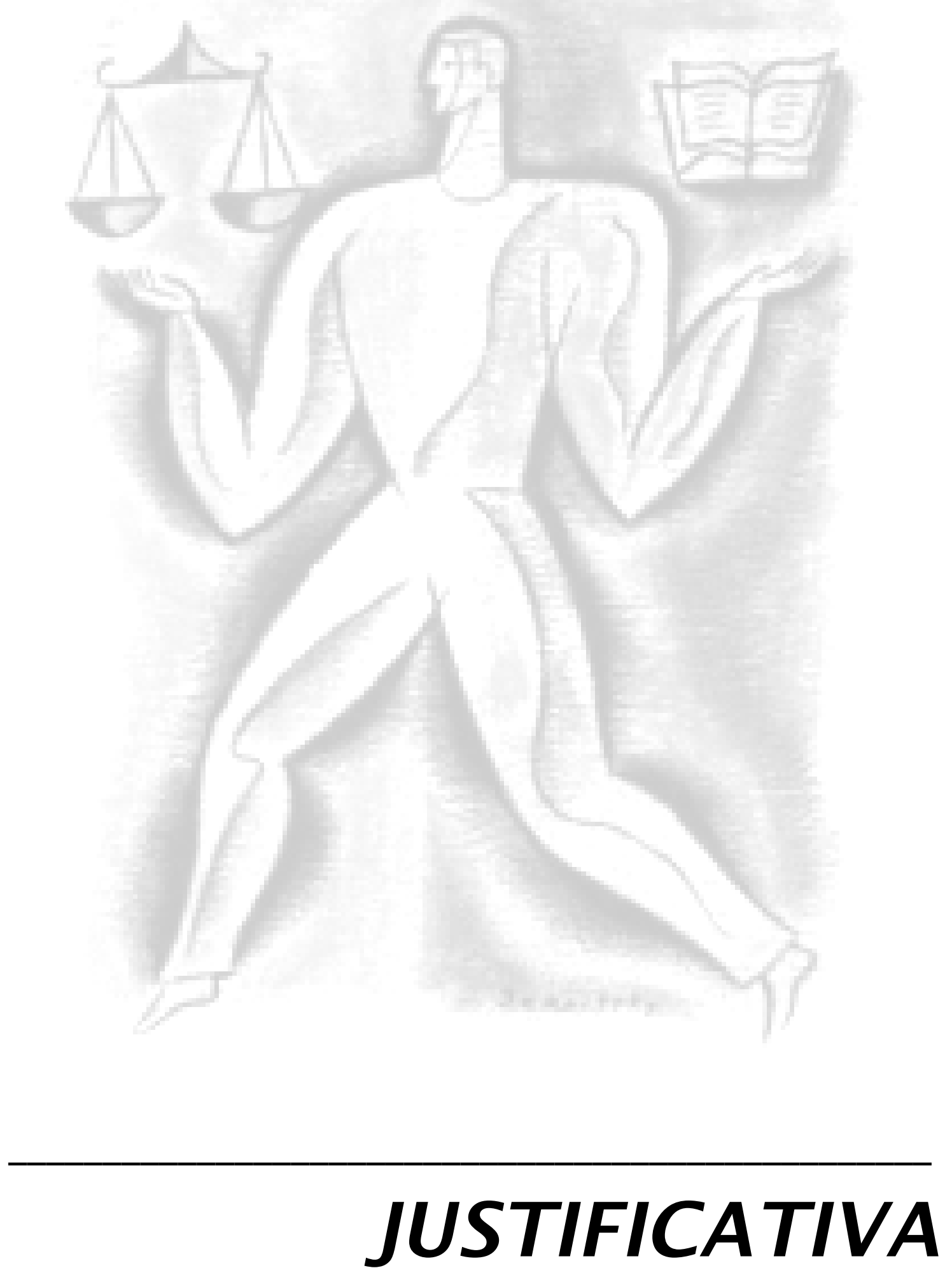




\section{JUSTIFICATIVA}

O presente estudo justifica-se pelo fato de nos últimos anos ter ocorrido um significativo aumento no número de infrações éticas cometidas por cirurgiões-dentistas $^{1}$. Estes profissionais agem, muitas vezes, de forma irregular por desconhecer os artigos do Código de Ética Odontológica, ou não saber interpretá-los de forma correta, tornando necessária uma melhor conscientização dos profissionais odontólogos, para importância da correta compreensão do Código de Ética, possibilitando uma atuação ética e humanista com a mesma qualidade da atuação técnica e científica.

\footnotetext{
${ }^{1}$ Informações baseadas em dados recebidos via e-mail (ANEXOS 5, 6 e 7), dos Conselhos Regionais de Odontologia dos Estados de Minas Gerais, Espírito Santo e do Distrito Federal, sobre o número de processos éticos instaurados contra cirurgiões-dentistas nos últimos anos; e informações colhidas na matéria intitulada "Ajustando condutas, evitando punições" do Jornal do Conselho Federal de Odontologia, nº 66, Mai/Jun., 2005, p.10.
} 


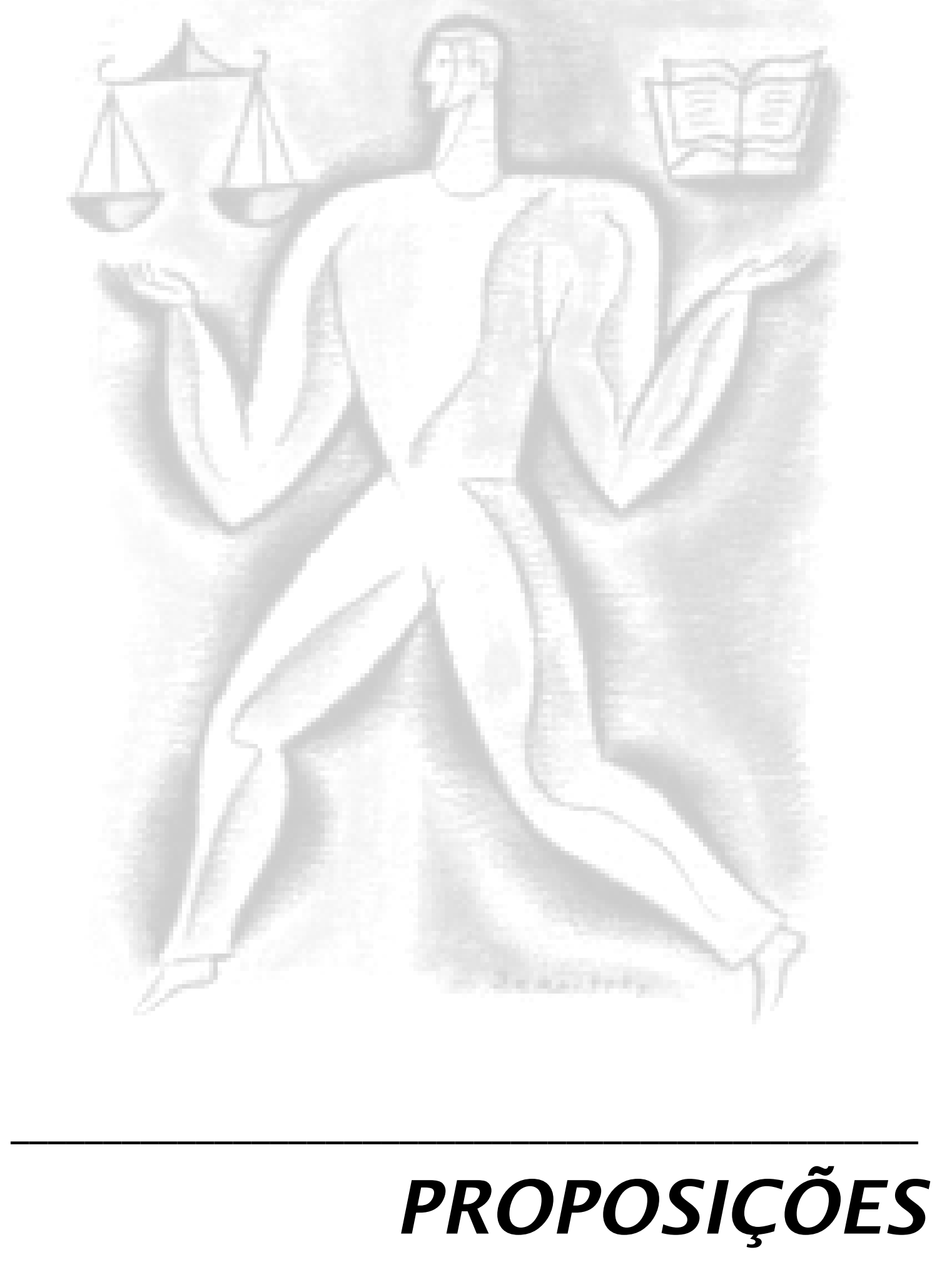




\section{PROPOSIÇÕES}

Este trabalho tem como proposições:

1. Analisar o conhecimento dos acadêmicos do último ano de graduação em Odontologia, e dos profissionais cirurgiõesdentistas, no município de Bauru, Estado de São Paulo, sobre os aspectos éticos da odontologia;

2. Verificar se existe diferença estatisticamente significante quanto ao nível de conhecimento do Código de Ética Odontológica, quando comparado os diferentes grupos:

- acadêmicos do último ano de graduação em Odontologia de Universidades pública e privadas, do município de Bauru;

- cirurgiões-dentistas que atuam somente em consultório ou clínica no município de Bauru;

- cirurgiões-dentistas que atuam em consultório ou clínica e cursam pós-graduação (especialização) em Instituições de Ensino ou Entidades de Classe, no município de Bauru. 


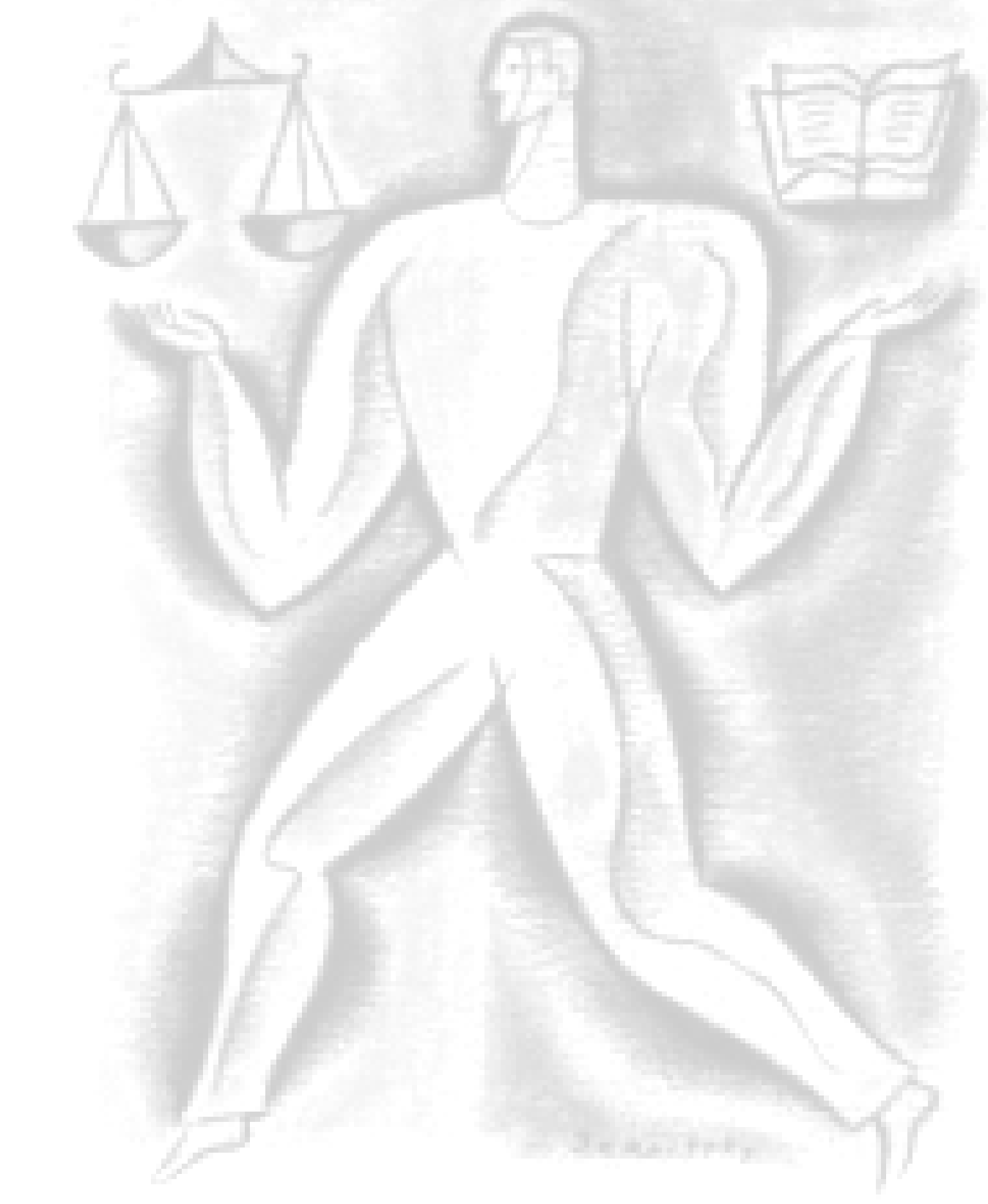

METODOLOGIA 


\section{METODOLOGIA}

Para a realização do presente estudo, inicialmente, o projeto de pesquisa e toda a documentação pertinente foram enviados ao Comitê de Ética em Pesquisa com Seres Humanos da FOB-USP.

O projeto foi aprovado pela referida comissão em reunião realizada no dia 26 de abril de 2006, sob o número 27/2006 (ANEXO 1 - pág. 80).

Quanto às etapas do projeto, a metodologia foi composta da seguinte forma:

- Realizou-se uma busca detalhada na literatura através das diversas bases de dados eletrônicas: Base de dados da Universidade de São Paulo - Dedalus (www.usp.br/sibi), Bibliografia Brasileira de Odontologia - BBO (www.bireme.br), Periódicos Capes (www.periodicos.capes.gov.br), Biblioteca Digital da Unicamp (http://libdigi.unicamp.br), Biblioteca Digital da Unesp (http://www.biblioteca.unesp.br/bibliotecadigital), Biblioteca Digital de Teses e Dissertações da USP (www.teses.usp.br), a fim de possibilitar uma ampla visão do assunto.

- Para avaliar o conhecimento dos acadêmicos e dos profissionais foi elaborado um questionário (ANEXOS 3 e 4 respectivamente), com questões fechadas, dividido em duas partes: 
Parte I. Voltada à caracterização da amostra, sem contudo, solicitar a identificação pessoal dos sujeitos participantes da pesquisa. Para os profissionais, solicitava informações como: Universidade que cursou, tempo de formado, faixa etária, região do país onde se formou, e se a atuação profissional é somente clínica ou cursa pós-graduação. Para os acadêmicos do último ano de graduação em Odontologia, continha as questões: a Universidade que cursa é pública ou privada? E, qual a faixa etária em que se encontra?

Parte II. Composta por seis questões objetivas, que versavam sobre o conteúdo de alguns dos principais artigos do Código de Ética Odontológica (ANEXO 8), como: publicidade e propaganda, direitos fundamentais dos cirurgiões-dentistas, responsável técnico, infrações éticas e profissões regulamentadas.

\section{Estudo piloto:}

- Realizou-se um estudo piloto aplicando o questionário a dez ( $n=10)$ acadêmicos do último ano de graduação em Odontologia em Universidades de Bauru-SP, e vinte $(n=20)$ profissionais cirurgiões- 
dentistas, destes, dez $(n=10)$ tinham atuação exclusivamente clínica, e dez ( $n=10)$ atuavam em consultório ou clínica e cursavam pósgraduação em nível de especialização.

- Após a tabulação dos dados em planilha excel, pontuou-se com notas de zero (0.0) a dez (10.0) as questões da segunda parte do questionário (ANEXO 3 - questões de 3 a 8; e ANEXO 4 - questões de 6 a 11), pertinentes ao Código de Ética Odontológica, da seguinte forma:

- A primeira questão, era considerada correta se assinaladas apenas as informações obrigatórias, atribuindo 2,0 pontos; considerada meio-certa se assinaladas, além das informações obrigatórias, outras facultativas, atribuindo 1,0 ponto; e considerada errada se deixado de assinalar alguma das informações obrigatórias, ou se marcada alguma informação proibida, não obtendo nenhum ponto.

- Como a terceira questão era complementar a segunda, optou-se por pontuar com 1,0 ponto cada questão respondida corretamente.

- As outras três questões, quando respondidas corretamente, recebiam 2,0 pontos cada uma. 
- Após análise estatística da pontuação dos questionários, chegou-se a um desvio padrão de um virgula noventa e dois pontos $(\mathrm{dp}=1,92)$.

- Considerando significante uma diferença de um ponto ou mais (dif $>1.0$ ) entre os grupos, e utilizando um poder de teste de $80 \%$ com nível de significância de $5 \%(p<0,05)$, concluiu-se que a amostra mínima necessária para testar uma hipótese de diferença entre os grupos, seria de $\mathrm{n}=46$ sujeitos para cada grupo.

\section{Participação dos acadêmicos de graduação em Odontologia:}

- A amostra foi composta pelos acadêmicos do último ano do curso de graduação em Odontologia em 2006, nas três entidades de ensino superior do município de Bauru que possuem o curso de Odontologia: Faculdade de Odontologia de Bauru - Universidade de São Paulo (FOB-USP), Universidade do Sagrado Coração (USC) e Universidade Paulista (UNIP).

- Após a aquiescência das entidades e dos coordenadores dos cursos, foram agendadas datas, onde foi possível o pesquisador aplicar o questionário aos alunos presentes em sala de aula. Estes questionários foram aplicados nos meses de agosto e setembro de 2006.

- Participaram da pesquisa, mediante assinatura do termo de consentimento livre e esclarecido e respondendo ao questionário 
proposto oitenta e um alunos $(n=81)$, em um universo de noventa e nove alunos ( $\mathrm{n}=99$ ), configurando $81,81 \%$ dos alunos do último ano dos cursos de graduação em Odontologia do município de Bauru-SP, no ano de 2006.

- Para se trabalhar com amostras uniformes, dos oitenta e um questionários respondidos, foram selecionados, de forma aleatória, vinte e cinco questionários de alunos da Universidade pública, e vinte e cinco questionários de alunos das Universidades privadas, totalizando cinqüenta alunos participantes.

- A título de conhecimento, estes alunos tiveram disciplinas que abordavam a ética e o Código de Ética Odontológica, em períodos diferentes. Os alunos da FOB-USP e da UNIP, receberam estas informações no $2^{\circ}$ ano do curso de graduação. Já os alunos da USC, tiveram estas informações no último ano de graduação.

\section{Participação dos profissionais cirurgiões-dentista:}

- A amostra foi composta por cirurgiões-dentistas que atuam em consultórios e clínicas no município de Bauru, além de profissionais que cursam pós-graduação (especialização) em algumas das Instituições de Ensino e Entidades de Classe do mesmo município, sendo estas: Associação Paulista de Cirurgiões Dentistas - Regional Bauru (APCD), Faculdade de Odontologia de Bauru - Universidade de 
São Paulo (FOB-USP), Fundação Bauruense de Estudos Odontológicos (FUNBEO), Hospital de Reabilitação de Anomalias Crânio-Faciais (CENTRINHO); Sociedade de Promoção Social do Fissurado Lábio Palatal (PROFIS).

- Os cirurgiões-dentistas que atuam em consultórios ou clínicas, foram visitados em seus estabelecimentos pelo pesquisador, e convidados a participar da pesquisa. No caso dos alunos de especialização, após autorização das entidades e dos coordenadores dos cursos, era feito o convite aos profissionais presentes em sala de aula, em uma data prédeterminada. Estes questionários foram aplicados no período compreendido entre maio e outubro de 2006.

- Participaram da pesquisa, mediante assinatura do termo de consentimento livre e esclarecido e respondendo ao questionário proposto, $n=100$ sujeitos da pesquisa, destes, $n=50$ com atuação exclusivamente clínica, não estando matriculado em nenhum curso de pós-graduação em Odontologia, e n=50 alunos de especialização que também atuam em consultório ou clínica.

\section{Análise estatística:}

- Os resultados foram submetidos à análise estatística descritiva, por meio de gráficos e tabelas. 
- Posteriormente os questionários dos acadêmicos e dos profissionais foram pontuados de forma idêntica a citada no estudo piloto. Estes dados foram inseridos em planilha excel e submetidos ao teste estatístico de Análise de variância - Um critério de classificação (ANOVA). Para o teste foi adotado um nível de significância de 5\% $(p<0.05)$. 


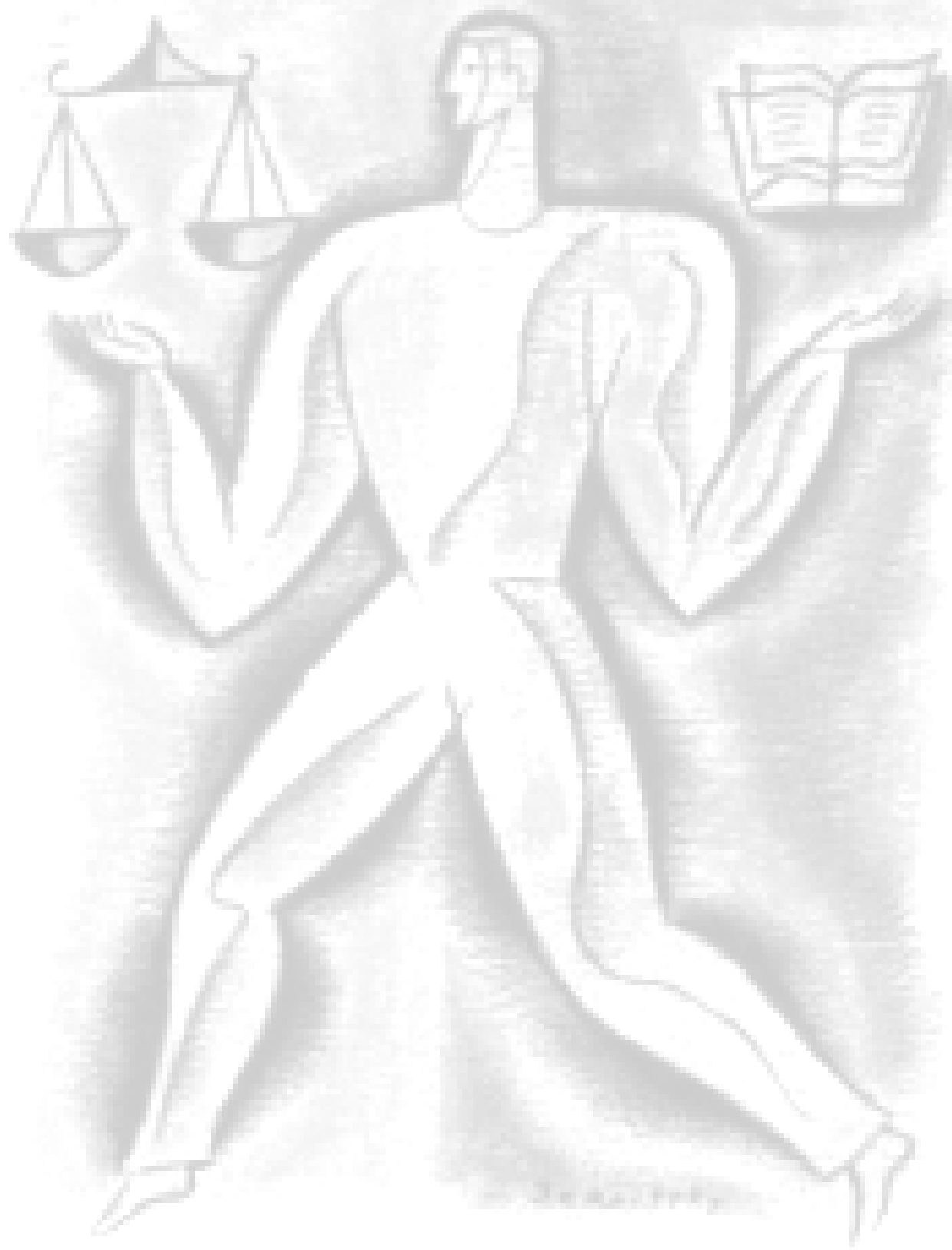

RESULTADOS 


\section{RESULTADOS}

Os resultados obtidos, após análise estatística, estão abaixo transcritos:

\subsection{Caracterização das amostras (Parte I do questionário)}

6.1.1 Acadêmicos (GRUPO I - alunos do $4^{\circ}$ ano de graduação em odontologia das Universidades de Bauru-SP)

Nas duas primeiras questões do questionário aplicado aos acadêmicos de Odontologia (ANEXO 3), foi possível identificar o perfil da amostra estudada, como pode ser visualizado na FIGURA 6.1.

Composta, em sua maioria, por jovens na faixa etária de 18 a 24 anos de idade ( $n=43-86 \%)$, cursando o último ano de graduação em Universidades pública e privadas ( $n=25$ e $n=25$ respectivamente).

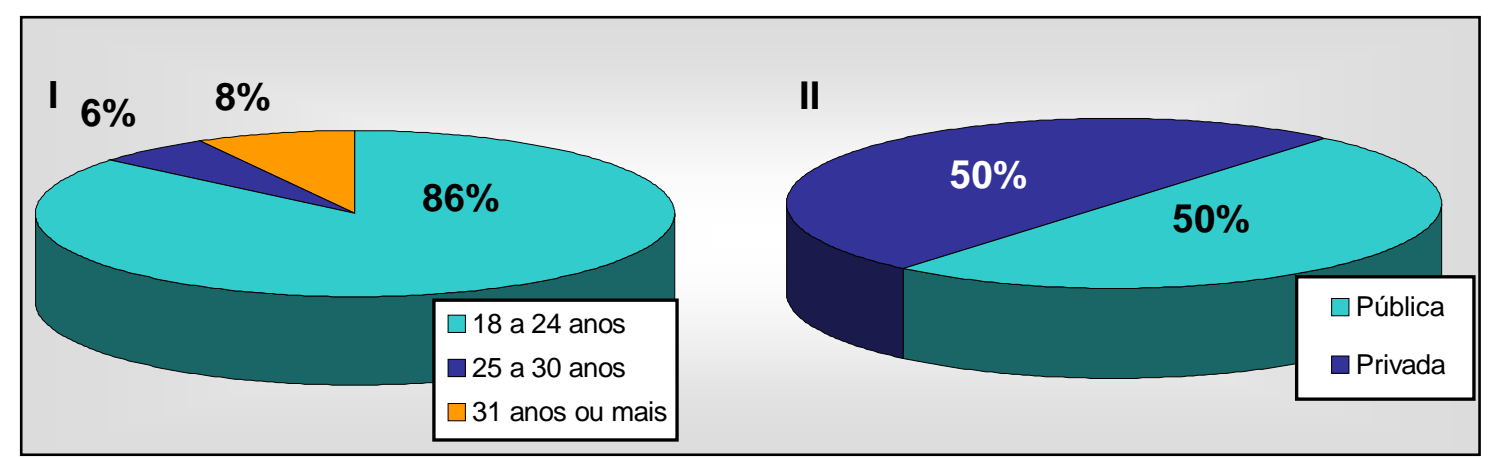

FIGURA 6.1 - Representação gráfica segundo a faixa etária (I) e o tipo de instituição que freqüentam (II) os acadêmicos do último ano de graduação em Odontologia do município de Bauru-SP. 
6.1.2 Profissionais clínicos (GRUPO II - cirurgiões-dentistas que atuam somente em consultório ou clínica no município de Bauru-SP)

Nas questões de um a quatro do questionário aplicado (ANEXO 4), foi possível verificar o perfil da amostra, conforme visualizado na FIGURA 6.2.

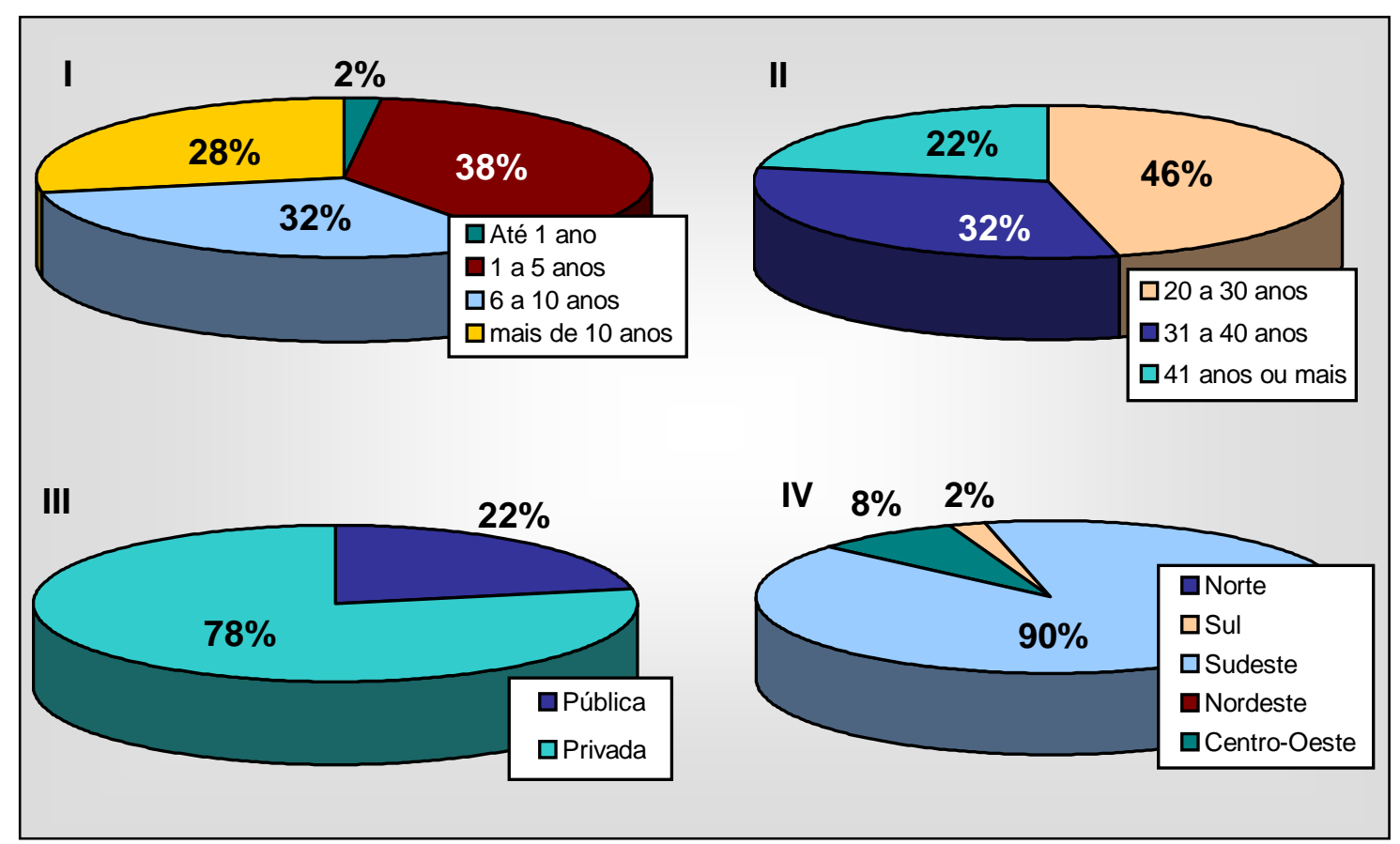

FIGURA 6.2 - Representação gráfica segundo o tempo de formação (I), a faixa etária (II), o tipo de instituição que freqüentou (III) e a localização da faculdade (IV) dos cirurgiões-dentistas que atuam somente em consultório ou clínica no município de Bauru-SP. 
Quanto ao tempo de conclusão do curso de graduação em Odontologia: $\mathrm{n}=1(2 \%)$ tinha até um ano de formado; $\mathrm{n}=19$ (38\%) tinham de um a cinco anos de formado; $n=16$ (32\%) tinham de seis a dez anos de formado; e $n=14$ (28\%) concluíram o curso há mais de dez anos.

Quanto à região do país onde concluíram o curso de graduação: $n=45$ (90\%) assinalaram a região Sudeste; $\mathrm{n}=4$ (8\%) marcaram a região CentroOeste; e n=1 (2\%) marcou a região Sul. As demais regiões do país, Norte e Nordeste, não foram assinaladas por nenhum participante.

A Universidade onde concluíram a graduação era pública para $n=11$ participantes (22\%), e privada para $\mathrm{n}=39$ participantes $(78 \%)$.

Quanto à faixa etária dos profissionais participantes: n=23 (46\%) estão com idade entre vinte e trinta anos; $n=16(32 \%)$ na faixa etária de trinta e um a quarenta anos; e n=11 (22\%) estão com quarenta e um anos de idade ou mais.

6.1.3 Profissionais cursando especialização (GRUPO III - cirurgiõesdentistas que atuam em consultório ou clínica, e cursam pósgraduação - especialização)

Nas questões de um a quatro do questionário aplicado (ANEXO 4), foi possível verificar o perfil da amostra, conforme visualizado na FIGURA 6.3. 


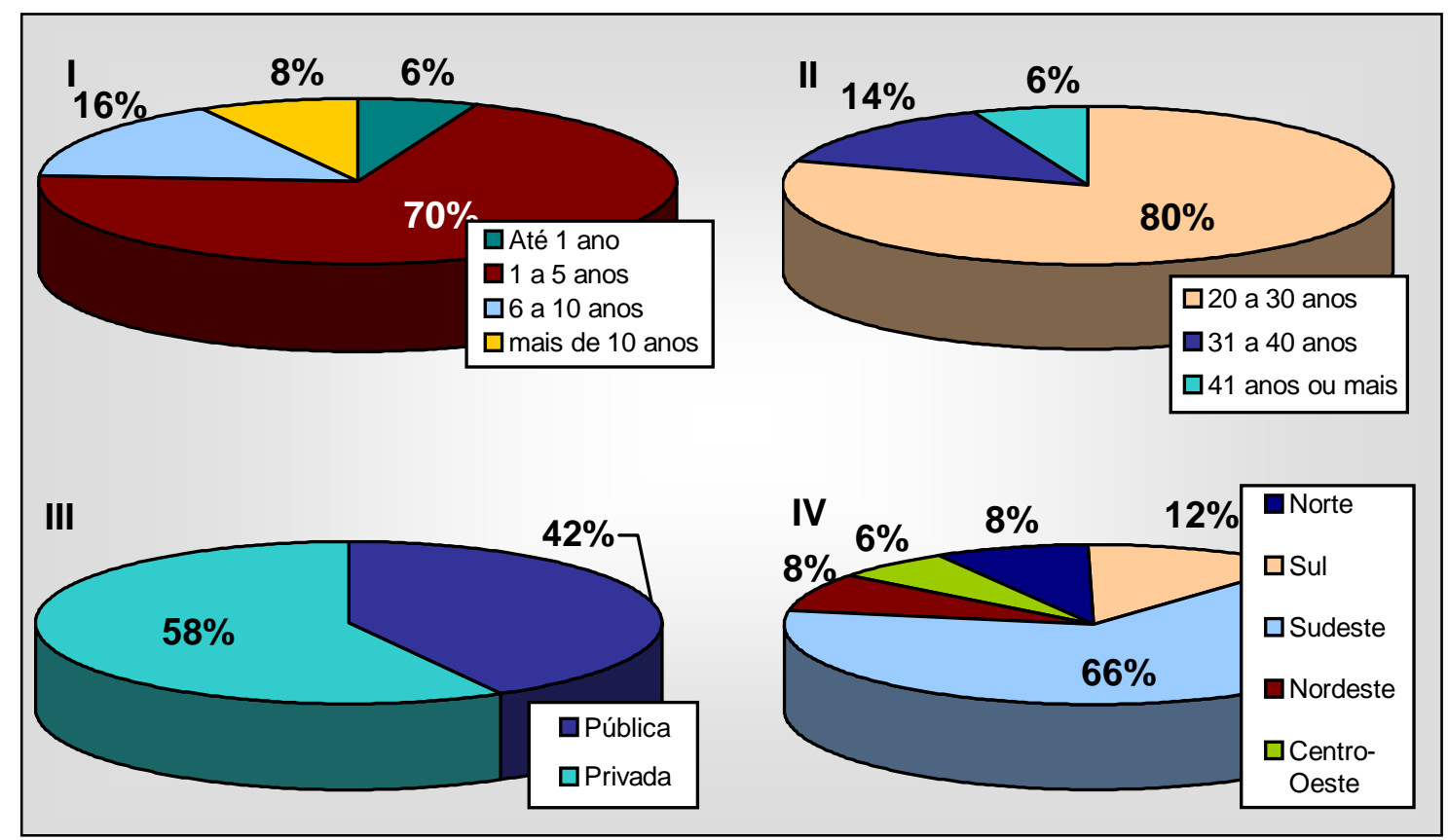

FIGURA 6.3 - Representação gráfica segundo o tempo de formação (I), a faixa etária (II), o tipo de instituição que freqüentou (III) e a localização da faculdade (IV) dos cirurgiões-dentistas que atuam em consultório ou clínica e cursam pós-graduação (especialização) em instituições no município de Bauru-SP.

Quanto ao tempo de conclusão do curso de graduação em Odontologia: n=3 (6\%) tinham até um ano de formado; $n=35$ (70\%) tinham de um a cinco anos de formado; $n=8(16 \%)$ tinham de seis a dez anos de formado; e $n=4(8 \%)$ concluíram o curso há mais de dez anos.

Quanto à região do país onde concluíram o curso de graduação: n=4 (8\%) assinalaram a região Norte; $n=6(12 \%)$ a região Sul; $n=33(66 \%)$ a região 
Sudeste; $\mathrm{n}=4$ (8\%) a região Nordeste; e $\mathrm{n}=3$ (6\%) marcaram a região CentroOeste.

A Universidade onde concluíram a graduação era pública para $n=21$ participantes (42\%), e privada para $\mathrm{n}=29$ participantes $(58 \%)$.

Quanto à faixa etária dos profissionais participantes: n=40 (80\%) estão com idade entre vinte e trinta anos; $n=7$ (14\%) na faixa etária de trinta e um a quarenta anos; e n=3 (6\%) estão com quarenta e um anos de idade ou mais.

\subsection{Conhecimento do Código de Ética Odontológica (Parte II do questionário)}

Os resultados obtidos aqui, estão apresentados de forma conjunta entre os três grupos (Acadêmicos, Profissionais clínicos e Profissionais cursando especialização), visto que, a segunda parte do questionário era comum aos três grupos, além de tornar possível a comparação entre eles e com o total geral.

Quando avaliado o grau de entendimento do Código de Ética Odontológica, em seu Art. $33^{\circ}$ (pág. 98 do ANEXO 8), que trata das informações que devem constar obrigatoriamente nos anúncios, placas e impressos, foram obtidos os seguintes resultados apresentados na TABELA 6.1. 
TABELA 6.1 - Número e porcentagem de respostas, separadas por grupo, referentes a quais informações devem constar obrigatoriamente nos anúncios, placas e impressos, segundo o Código de Ética Odontológica.

\begin{tabular}{lcccccccc}
\multicolumn{1}{c}{ GRUPO* } & \multicolumn{2}{c}{ I } & \multicolumn{2}{c}{ II } & \multicolumn{3}{c}{ III } & \multicolumn{2}{c}{ Total } \\
\hline \multicolumn{1}{c}{ Opção de resposta } & $\mathbf{N}^{\mathbf{0}}$ & $\%$ & $\mathbf{n}^{\mathbf{0}}$ & $\%$ & $\mathbf{n}^{\circ}$ & $\%$ & $\mathbf{n}^{\circ}$ & $\%$ \\
O nome do profissional** & 50 & 100 & 47 & 94 & 50 & 100 & 147 & 98 \\
O telefone & 29 & 58 & 33 & 66 & 23 & 46 & 85 & 56,6 \\
O horário de atendimento & 6 & 12 & 17 & 34 & 1 & 2 & 24 & 16 \\
Os preços & 1 & 2 & - & - & - & - & 1 & 0,6 \\
O número do CPF & 1 & 2 & 2 & 4 & 1 & 2 & 4 & 2,6 \\
O endereço & 25 & 50 & 32 & 64 & 26 & 52 & 83 & 55,3 \\
As técnicas de tratamento & 1 & 2 & - & - & - & - & 1 & 0,6 \\
A profissão** & 38 & 76 & 38 & 76 & 37 & 74 & 113 & 75,3 \\
As formas de pagamento & - & - & - & - & - & - & - & - \\
As especialidades & 37 & 74 & 35 & 70 & 25 & 50 & 97 & 64,6 \\
O no de inscrição no CRO ${ }^{* *}$ & 49 & 98 & 45 & 90 & 50 & 100 & 144 & 96 \\
\hline
\end{tabular}

*Grupo I - Acadêmicos do último ano de graduação em odontologia do município de Bauru-SP; Grupo II - cirurgiões-dentistas que atuam em consultório ou clínica no município de Bauru-SP; Grupo III - Cirurgiões-dentistas que atuam em consultório ou clínica, e cursam especialização.

** Opções corretas, segundo o Código de Ética Odontológica.

Quando abordado sobre o Art. $3^{\circ}$. Inciso $\vee$ do Código de Ética Odontológica (pág. 91 do ANEXO 8), que trata dos direitos fundamentais dos profissionais inscritos, onde questionado se o cirurgião-dentista tem direito de desistir do atendimento do paciente durante o tratamento: entenderam que "SIM", n=30 acadêmicos (60\%), n=37 profissionais clínicos (74\%) e n=37 profissionais que cursam especialização (74\%) (FIGURA 6.4).

Já para n=20 acadêmicos (40\%), n= 10 profissionais clínicos (20\%) e $\mathrm{n}=13$ profissionais que cursam especialização (26\%), o cirurgião-dentista "NÃO" tem direito de renunciar ao atendimento do paciente durante o tratamento (FIGURA 6.4). 
No "Grupo II", n=3 profissionais (6\%) deixaram esta questão em branco.

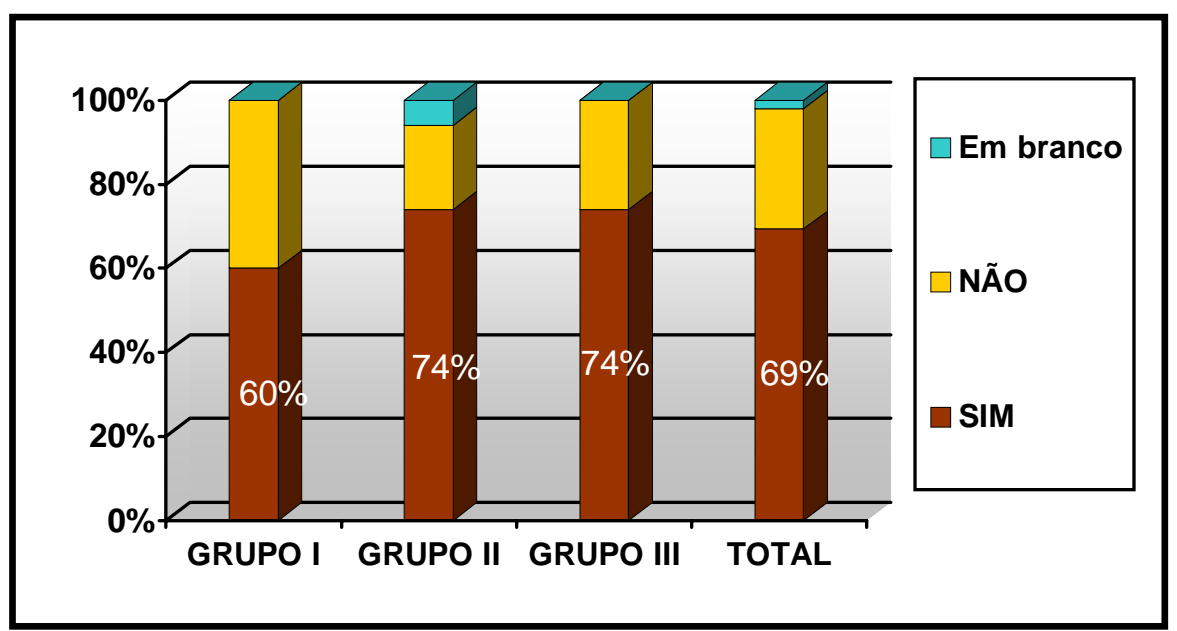

FIGURA 6.4 - Representação gráfica das respostas, separada por grupos, quando perguntado se o cirurgião-dentista tem direito de desistir do atendimento do paciente durante o tratamento.

Complementando a pergunta anterior, a questão seguinte perguntava em quais situações abaixo relacionadas, o cirurgião-dentista poderia desistir do atendimento do paciente durante o tratamento.

Situação A - quando, ao seu critério, o profissional constate fatos que prejudiquem o bom relacionamento com o paciente;

Situação B - quando o profissional bem entender, inclusive sem necessidade de justificativa;

Situação C - quando, a qualquer momento, o profissional constate que o paciente é portador de doença infecto contagiosa; 
Todos os participantes que assinalaram "NÃO" na questão anterior, ou deixaram em branco, não marcaram nenhuma das situações acima citadas. Desta forma, como visualizado na FIGURA 6.5, temos que:

Dos que marcaram "SIM" na questão anterior, $\mathrm{n}=30$ (100\%) dos acadêmicos de Odontologia (GRUPO I), assinalaram a opção "A".

Do $\mathrm{n}=37$ profissionais clínicos (GRUPO II), n=35 (94,5\%) assinalaram a opção "A", n=2 (5,4\%) marcou a opção "B", e n=2 (5,4\%) assinalou a opção "C".

Do $n=37$ profissionais alunos de especialização (GRUPO III), todos (100\%) assinalaram a opção "A".

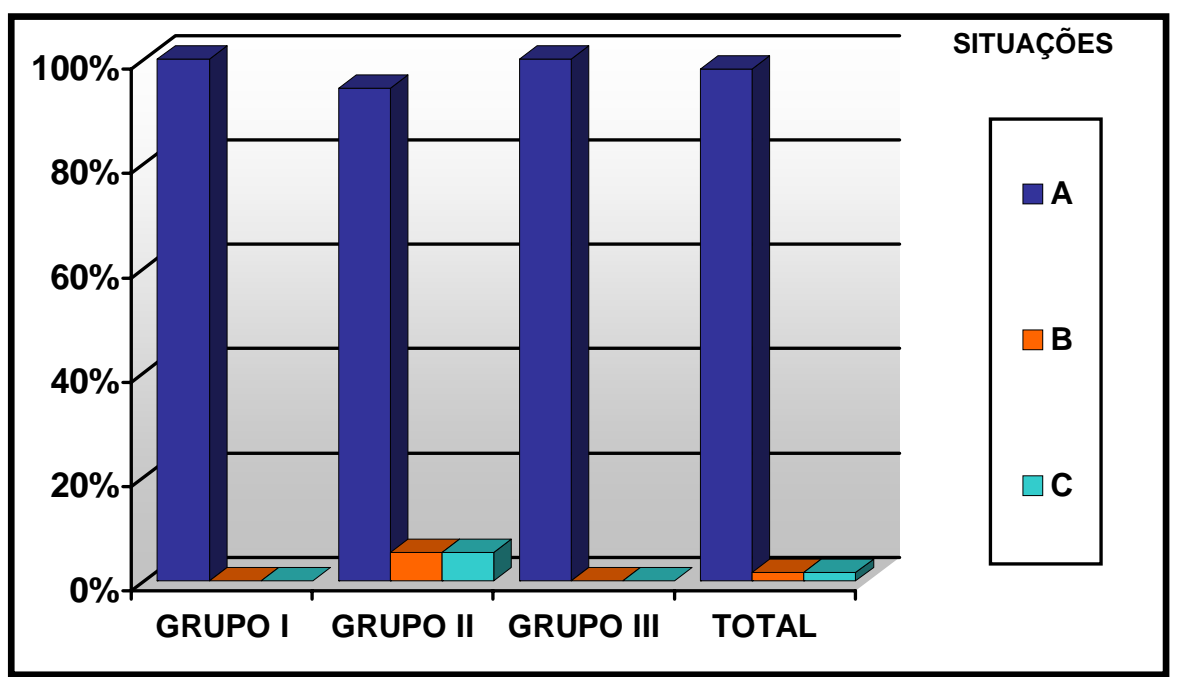

FIGURA 6.5 - Representação gráfica das respostas dos participantes que assinalaram "SIM" na questão anterior, quando perguntado em quais situações o cirurgião-dentista pode renunciar ao atendimento do paciente durante o tratamento. 
Outro quesito investigado, foi com relação ao cirurgião-dentista inscrito no conselho, proprietário ou responsável técnico de clínica, se este responderia eticamente por erro de colega que atue sob sua responsabilidade.

Dos participantes, responderam que "sim": GRUPO I - n=47 graduandos (94\%); GRUPO II - n=41 profissionais (82\%); e GRUPO III - n=45 alunos de especialização (90\%).

E responderam que "não": GRUPO I - n=2 graduandos (4\%); GRUPO II - n=7 profissionais (14\%); e GRUPO III - n=5 alunos de especialização (10\%).

Além destes, deixaram em branco: $n=1$ acadêmico (2\%), e 2 profissionais clínicos (4\%). (FIGURA 6.6)

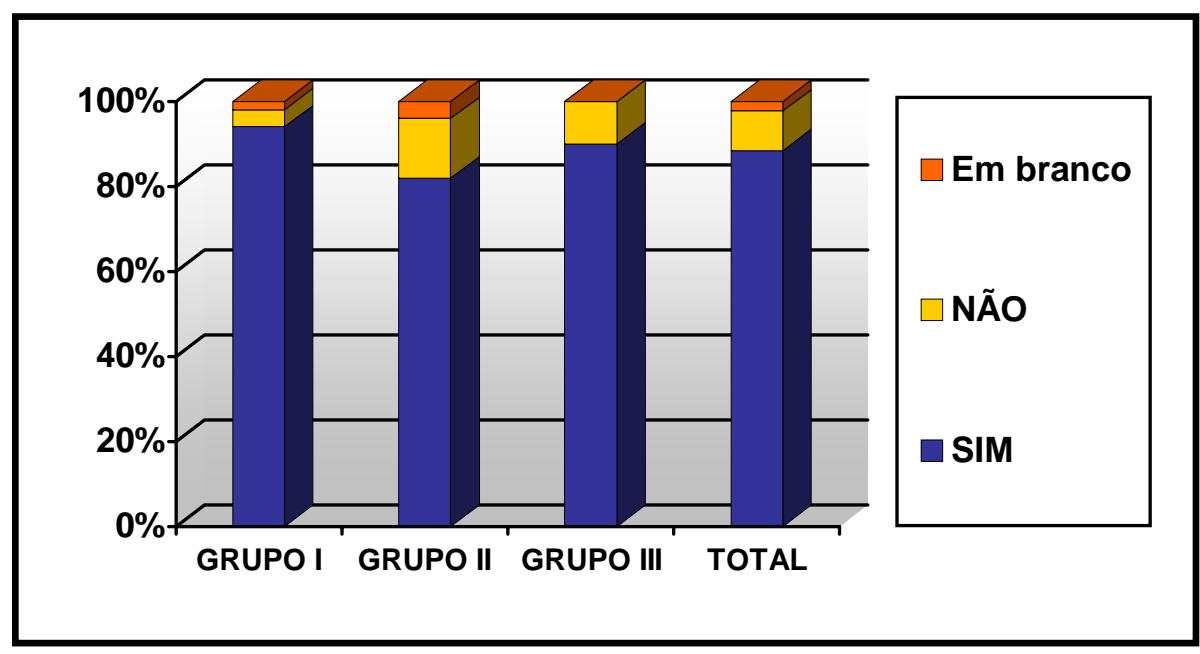

FIGURA 6.6 - Representação gráfica das respostas dos participantes, divididos em grupos, quando perguntado se o cirurgião-dentista inscrito no conselho, proprietário ou responsável técnico de clínica, responderia eticamente por erro de colega que atue sob sua responsabilidade. 
Quando questionado sobre quais das situações a baixo, constitui(em) infração(ões) ética(s):

Situação A - esclarecer os propósitos, ricos, custos e alternativas de tratamento;

Situação B - prestar atendimento de urgência ou de emergência a menor de idade sem a prévia autorização dos responsáveis ou representantes legais;

Situação C - receber ou dar algum tipo de gratificação a outro profissional, por encaminhamento de pacientes.

Levando em consideração que era possível assinalar mais de uma situação, foi possível obter os seguintes resultados (FIGURA 6.7):

GRUPO I - n=5 (10\%) assinalaram a opção "A", n=7 (14\%) marcaram a opção "B", n=41 (82\%) optaram pela "C".

GRUPO II - n=4 (8\%) assinalou a opção "A", n=27 (54\%) marcaram a opção "B", n=29 (58\%) optaram pela "C". Dois participantes deixaram em branco.

GRUPO III - nenhum assinalou a opção "A", n=20 (40\%) marcaram a opção "B", n=42 (84\%) optaram pela "C". 


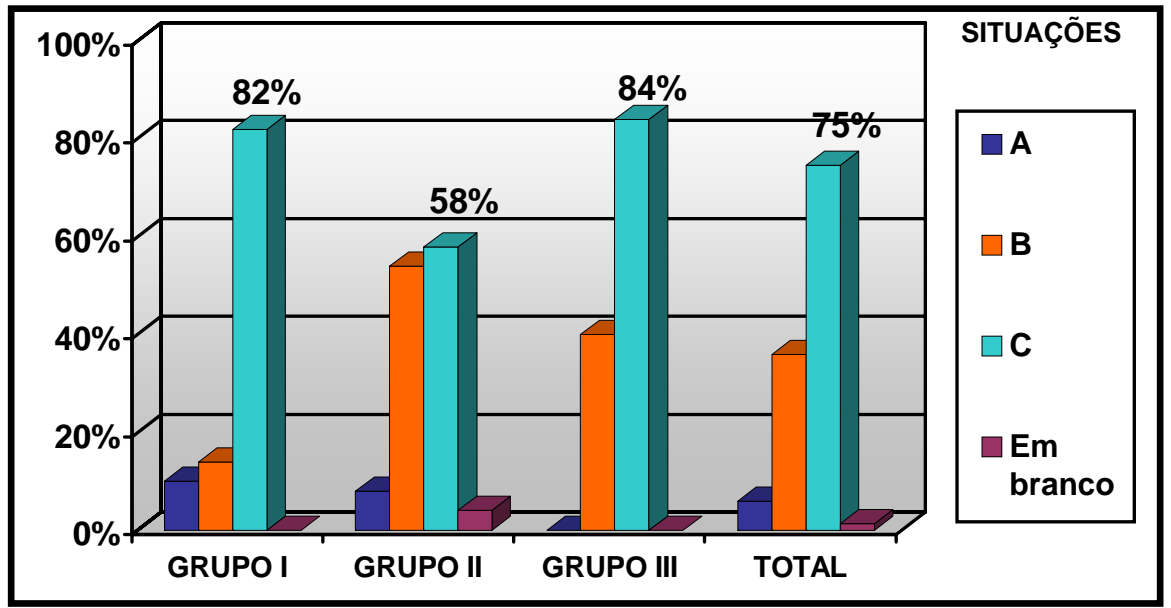

FIGURA 6.7 - Representação gráfica das respostas dos participantes, divididos em grupos, quando questionado sobre quais das opções constitui(em) infração(ões) ética(s), segundo o Código de Ética Odontológica.

Na última questão, referente a quais profissionais se aplica o Código de Ética Odontológico, foram obtidos os seguintes resultados apresentados na TABELA 6.2.

TABELA 6.2 - Número e porcentagem de respostas, separadas por grupo, referentes a quais profissionais se aplica o Código de Ética Odontológica.

\begin{tabular}{|c|c|c|c|c|c|c|c|c|}
\hline \multirow{2}{*}{$\begin{array}{c}\text { GRUPO* } \\
\text { Opção de resposta }\end{array}$} & \multicolumn{2}{|c|}{ I } & \multicolumn{2}{|c|}{ II } & \multicolumn{2}{|c|}{ III } & \multicolumn{2}{|c|}{ TOTAL } \\
\hline & $n^{\circ}$ & $\%$ & $n^{\circ}$ & $\%$ & $n^{\circ}$ & $\%$ & $\mathbf{N}^{\circ}$ & $\%$ \\
\hline Somente o cirurgião dentista & 18 & 36 & 16 & 32 & 12 & 24 & 46 & 31 \\
\hline $\begin{array}{l}\text { cirurgião dentista, auxiliar de consultório } \\
\text { dentário e técnico em higiene dental }\end{array}$ & 7 & 14 & 6 & 12 & 19 & 38 & 32 & 21 \\
\hline $\begin{array}{l}\text { cirurgião dentista e técnico de prótese } \\
\text { dentária } \\
\text { cirurgião dentista, auxiliar de consultório }\end{array}$ & - & - & 4 & 8 & 1 & 2 & 5 & 3 \\
\hline $\begin{array}{l}\text { dentário, técnico em higiene dental, técnico } \\
\text { de prótese dentária e auxiliar de prótese } \\
\text { dentária }\end{array}$ & 25 & 50 & 16 & 32 & 18 & 36 & 59 & 40 \\
\hline Em branco & - & - & 8 & 16 & - & - & 8 & 5 \\
\hline TOTAL & 50 & 100 & 50 & 100 & 50 & 100 & 150 & 100 \\
\hline
\end{tabular}

*Grupo: I - acadêmicos do último ano de graduação em odontologia do município de Bauru-SP; II - cirurgiões-dentistas que atuam em consultório ou clínica no município de Bauru-SP; III cirurgiões-dentistas que atuam em consultório ou clínica, e cursam especialização. 


\subsection{Pontuação dos questionários, e comparação dos grupos}

Os questionários dos três grupos testados, após a pontuação, apresentaram os seguintes resultados:

Os 150 questionários pontuados apresentaram uma nota média de 5,84, com um desvio padrão de 1,86.

Analisando separadamente os grupos (TABELA 6.3), verificou-se uma nota média de 6,40 para os acadêmicos (GRUPO I), com um desvio padrão de 1,70. Já os profissionais clínicos (GRUPO II), apresentaram uma nota média de 5,08 , e um desvio padrão de 1,91 . Os profissionais clínicos que cursam especialização (GRUPO III), obtiveram uma nota média de 6,04, com um desvio padrão de 1,76.

Através do teste estatístico de Análise de variância - Um critério de classificação (ANOVA), verificou-se uma probabilidade $(p=0,001)$, possibilitando afirmar a hipótese de diferença entre os grupos.

Em seqüência, o Teste de Tukey, com nível de significância de 5\% $(p<0,05)$ apresentou diferença estatisticamente significante entre o GRUPO I e o GRUPO II, e entre o GRUPO II e o GRUPO III (TABELA 6.4). 
TABELA 6.3 - Mediana, média, desvio padrão, soma, valores mínimo e máximo, da pontuação dos questionários dos três grupos testados.

\begin{tabular}{cccccccc}
\hline GRUPO & Mediana & Média & D. padrão & Soma & Mínimo & Máximo & Número \\
\hline I & 7 & 6.40 & 1.70 & 320 & 2 & 9 & 50 \\
II & 5 & 5.08 & 1.91 & 254 & 0 & 9 & 50 \\
III & 6 & 6.04 & 1.76 & 302 & 3 & 10 & 50 \\
\hline
\end{tabular}

TABELA 6.4 - Teste de Tukey, com nível de significância de 5\% (p<0,05).

\begin{tabular}{cccc}
\hline Comparação & Diferença & Valor crítico & Interpretação \\
\hline Grupo I X Grupo II & 1.32 & 0.84 & SIGNIFICANTE \\
Grupo I X Grupo III & 0.36 & 0.84 & Não significante \\
Grupo II X Grupo III & -0.96 & 0.84 & SIGNIFICANTE \\
\hline
\end{tabular}




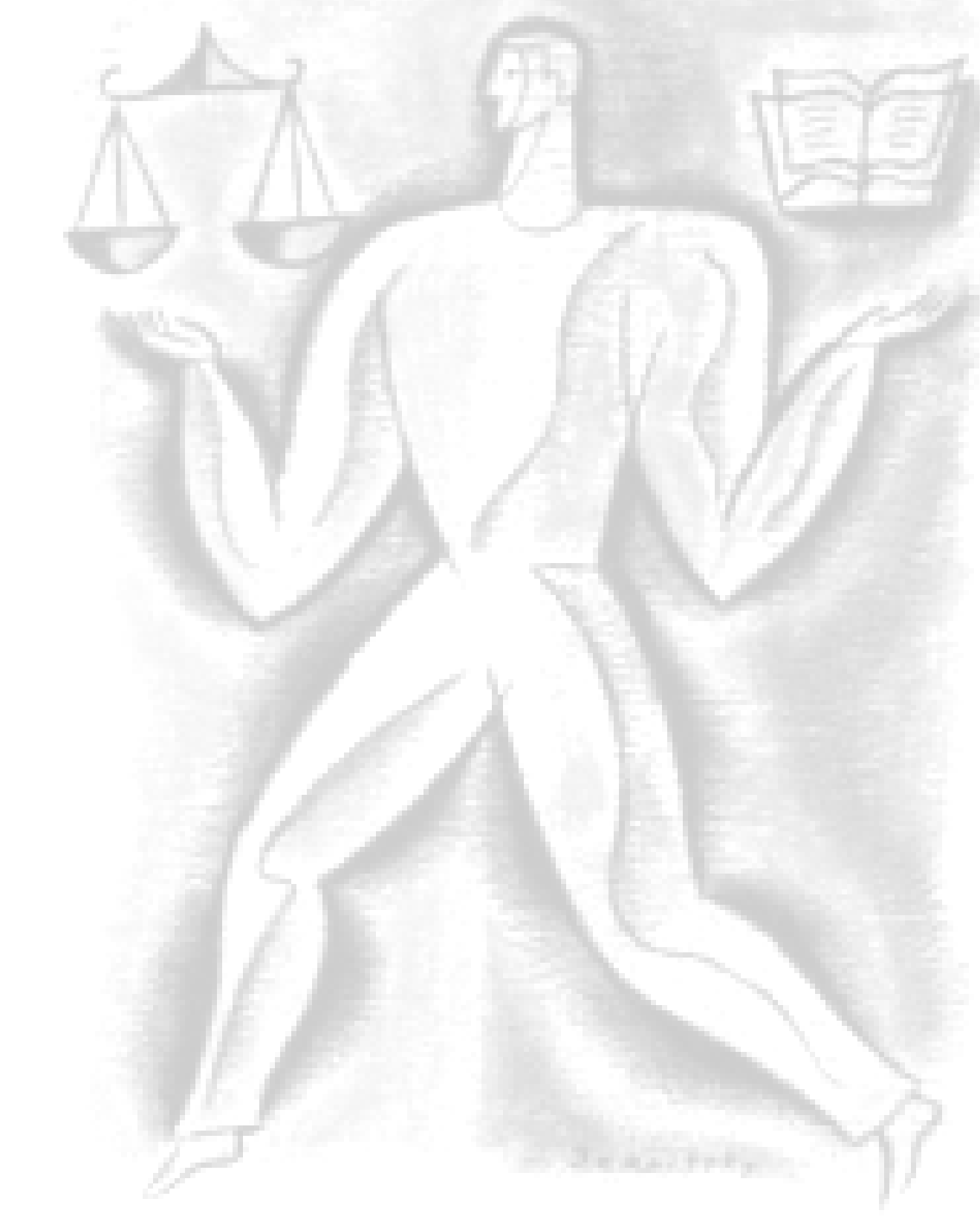

DISCUSSÃO 


\section{DISCUSSÃO}

A Odontologia, segundo VASCONSELLOS ${ }^{49}$, em 2003, encontra-se hoje em um momento de transição, onde os profissionais devem estar preparados para atuarem nesse novo contexto, onde estão inseridos os fenômenos da globalização e socialização dos cuidados à saúde.

Vale ressaltar, que o Código de Ética Odontológica é um dos instrumentos que abordam estas questões do relacionamento do profissional com seu paciente e dos profissionais entre si, sendo um dos principais referenciais para análise da ética odontológica ${ }^{36}$.

Foi baseado nisso que, através desse código deontológico da profissão odontológica, o presente trabalho objetivou analisar o conhecimento dos profissionais cirurgiões-dentistas, sobre os aspectos éticos de sua profissão. Mais que isso, verificar em diferentes grupos ou estágios da formação profissional, o nível desse conhecimento ético.

Partindo então, do primeiro estágio dessa formação, temos o estudante de graduação em Odontologia, que por sua condição, ainda não está sujeito a penalidades previstas no Código de Ética Odontológica, por não ser inscrito e registrado no Conselho Regional e no Conselho Federal de Odontologia. Contudo, segundo SAMICO ${ }^{44}$, em 1990, como estudante e como pessoa está sujeito a normas éticas de conduta, e deve ser instruído de princípios e normas éticas, bem como integrantes de diplomas legais, para que as pratique desde logo e tenha uma formação moral a par com as formações técnicas e 
científicas, preparando-se para ser o futuro profissional que se instrui desde a graduação até outros cursos da educação continuada.

Foi com esta visão, que o presente trabalho optou por analisar o conhecimento ético, além dos profissionais já formados, dos discentes do último ano dos cursos de graduação em Odontologia, justamente nessa condição de futuros profissionais que devem estar a par destas questões éticas e legais de sua profissão.

\subsection{Características da amostra}

De acordo com os resultados obtidos com a primeira parte dos questionários (ANEXOS 3 e 4), voltada à caracterização da amostra, nota-se que a maioria dos profissionais já formados, e os que ainda estão para se formar, são jovens na faixa etária de 20 a 30 anos de idade, sendo o grupo composto pelos profissionais exclusivamente clínicos (GRUPO II), o que apresentou uma distribuição mais homogênea entre as faixas etárias. Os profissionais já formados, cursando ou não especialização (GRUPOS II e III), são provenientes, principalmente, de Universidades privadas, localizadas na região sudeste do país, tendo a maioria pouco tempo de formado.

Estes dados apresentados estão de acordo com a pesquisa sobre o perfil do cirurgião-dentista no Brasil, encomendada pelas Entidades Nacionais de Odontologia, em abril de $2003^{20}$. Segundo a pesquisa, a faixa etária 
predominante dos profissionais no país, com $45,5 \%$ da amostra, vai até os 30 anos de idade, tendo $52,1 \%$ da amostra se formado em Universidade privada e $38,1 \%$ se formado há pelo menos cinco anos.

Esta realidade, evidencia uma das transformações que a Odontologia sofreu nos últimos anos, onde o aumento desenfreado no número de cursos de odontologia, principalmente nos grandes centros, lançou no mercado de trabalho um número excessivo de profissionais, que atualmente ainda lutam por seu espaço dentro da profissão. A titulo de exemplo, os dados do Conselho Federal de Odontologia ${ }^{12}$, apontam que 33,6\% dos 210.645 cirurgiões-dentistas registrados por todo país estão no estado de São Paulo.

Entretanto, segundo ROSENTHAL ${ }^{41}$, em 2001, devido a este elevado número de profissionais no mercado, a Odontologia começa a apresentar atualmente, uma outra configuração, onde nota-se uma queda acentuada na procura pelos cursos de odontologia.

A realidade encontrada durante a pesquisa nas Universidades do município de Bauru, condiz com a afirmação de Rosenthal, onde os cursos de odontologia, das instituições particulares, estão com suas turmas bastante reduzidas, visto que a procura por tal curso praticamente inexiste. Fato parecido vive a instituição pública, apesar de todas as vagas serem preenchidas a cada ano, nos últimos vestibulares a relação candidato/vaga apresentou uma queda significativa* .

\footnotetext{
* Informações baseadas nos dados encontrados no site da FUVEST: www.fuvest.com.br
} 


\subsection{Conhecimento do Código de Ética Odontológica}

Segundo SANTOS et al. $^{46}$, 2004, é necessário que o profissional cirurgião-dentista assuma um caráter ético no seu dia-dia, que interprete e compreenda o código de ética, propondo-se a respeitá-lo e executá-lo sempre, sem influência do temor imposto pelas punições decorrentes da sua infração.

7.2.1 Do anúncio, da propaganda e da publicidade

Como se verifica nas atividades dedicadas à prestação de serviço, pela característica que Ihes são peculiares no relacionamento com o público, o exercício da Odontologia exige o estabelecimento freqüente da comunicação com vários grupos. Entretanto, o direito a esta comunicação, está sob a égide da ética ${ }^{33}$.

Pensando nisso, a primeira questão que abordou o conhecimento do Código de Ética Odontológica (CEO), tratava do anúncio, da propaganda e publicidade (Art. 32 ao Art.36 do CEO - pág. 98-99 do ANEXO 8), onde perguntou-se sobre quais as informações são obrigatórias constar nos anúncios placas e impressos.

As opções, "o nome do profissional" e "o número de inscrição no CRO", foram assinaladas por praticamente todos os participantes (98\% e $96 \%$ respectivamente), contudo, aproximadamente $25 \%$ dos participantes não marcaram a opção "a profissão". Estas três opções configuram, segundo o 
Artigo 33 do Código de Ética Odontológica ${ }^{14}$, obrigatoriedade nos meios de comunicação e divulgação na odontologia.

A realidade, exemplificada na FIGURA 7.1, mostra que uma boa parte dos profissionais, acaba negligenciando, não apenas "a profissão", mas as outras informações também obrigatórias, quando fazem a divulgação ou propaganda do seu trabalho.

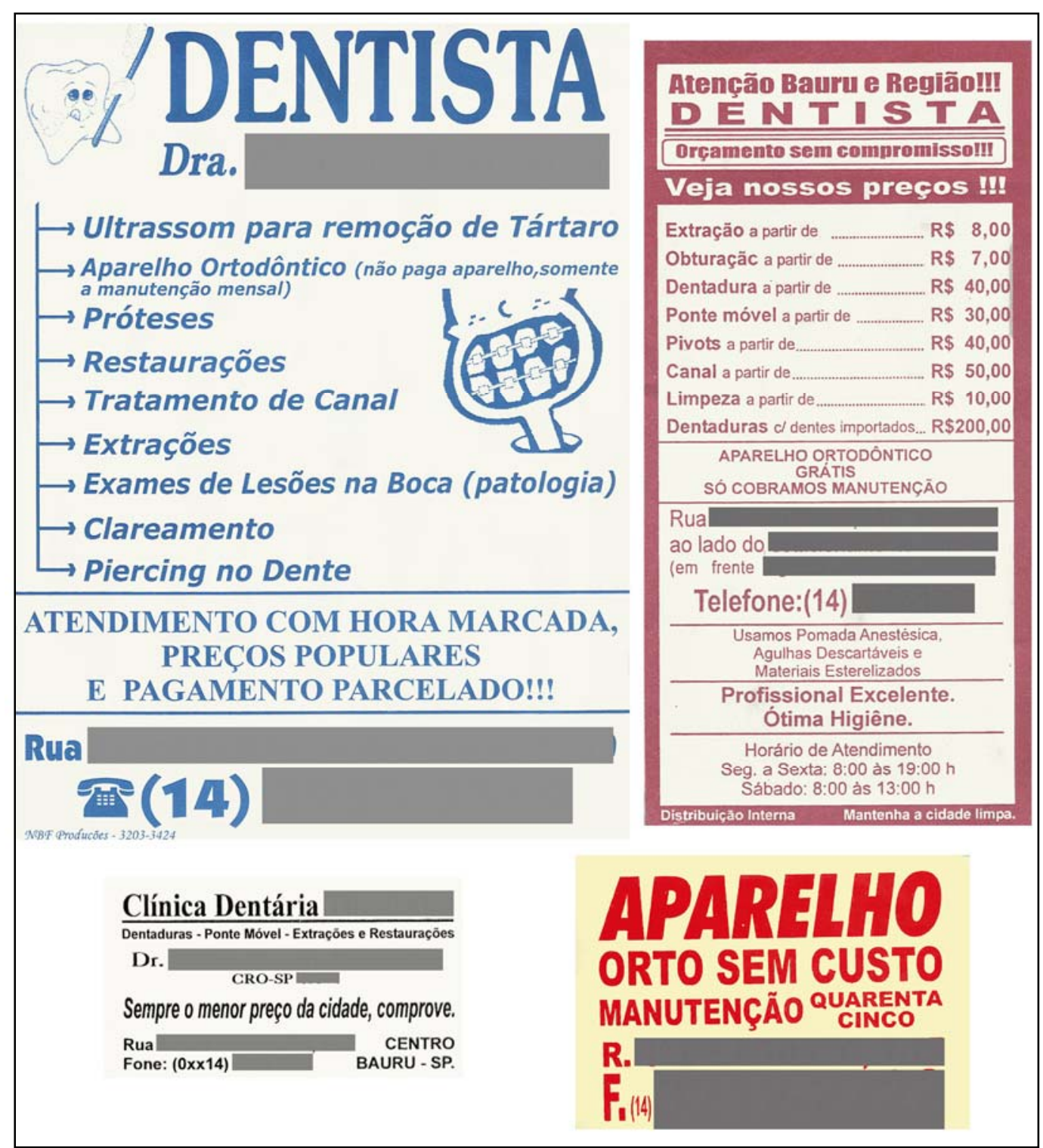

FIGURA 7.1 - Exemplos de propaganda irregular. 
Paralelo a isso, SALIBA et al. ${ }^{43}$, em 1996, observaram a ocorrência elevada de infrações pelos profissionais no tocante a publicidade quando pesquisaram as placas de consultórios odontológicos no município de Marília/SP. Foi encontrada uma alta porcentagem dessas placas (43,3\%), onde não constava o número de inscrição do responsável no Conselho Regional, infringindo assim os dispositivos legais da publicidade odontológica.

O Código de Ética Odontológica, após a alteração sofrida com a Resolução CFO-71, de 06 de junho de $2006^{16}$, permite, segundo o Artigo 33 Parágrafo $1^{\circ}$ (ANEXO 8 - pág. 98), que informações como: áreas de atuação, procedimentos e técnicas de tratamento, especialidades nas quais o cirurgiãodentista esteja inscrito no CRO, títulos de formação acadêmica, endereço, telefone, fax, endereço eletrônico, horário de trabalho, convênios, entre outras, venham a constar na comunicação e divulgação do profissional.

Dentre as informações acima citadas, e que foram colocadas como opção na questão que abordava o assunto (questão 3 do ANEXO 3, e questão 6 do ANEXO 4), "o telefone", "o endereço", e "as especialidades", foram as mais assinaladas pelos participantes, com 56,6\%, 55,3\% e $64,4 \%$ respectivamente. Isto demonstra um certo desconhecimento, por parte destes participantes, sobre quais informações são obrigatórias e quais são facultativas.

Já opções como, "os preços", marcada por apenas um participante, e "as formas de pagamento", não assinalada por ninguém, e que constituem infração ética, deixam evidente o conhecimento dos profissionais no tocante ao que é proibido. Entretanto, mesma observação feita nos quesitos obrigatórios, 
se aplica aqui, onde a realidade também demonstra que alguns profissionais, neste caso, não por falta de conhecimento, mas por um total desrespeito à ética profissional, incluem estas informações em seus meios de divulgação (FIGURA 7.1).

Concordando com isso, MENEZES ${ }^{33}$, já em 1982, lamentava que as profissões de saúde que, pela própria natureza da atividade que desenvolvem, deveriam manter-se resguardadas da avalanche mercantilista dominante, infelizmente, estavam por ela também envolvidas.

Um fato que comprova o exposto acima, é o elevado número de processos éticos instaurados contra cirurgiões-dentistas, por infrações referentes à publicidade e propaganda. $\operatorname{LUCAS}^{28}$, em 1999, realizou um levantamento dos processos éticos instaurados no CRO de Minas Gerais, no período de 1991 a 1995, e constatou que 22\% deles referiam-se a "panfletagem/propaganda/anúncios".

Atualmente estima-se que esta porcentagem tenha crescido, como exemplo, temos os dados fornecidos pelo CRO do estado do Espírito Santo (ANEXO 6), onde aproximadamente $50 \%$ dos processos instaurados, no período de 2000 a 2006, são referentes à publicidade em desacordo com as normas do Código de Ética Odontológica.

7.2.2 Do direito de renunciar ao atendimento do paciente 
A Odontologia é uma profissão liberal e tem como característica a liberdade do exercício de suas atividades. É uma liberdade relativa, pois é uma profissão que traz em si elevados interesses ligados à pessoa humana. Desse modo, nem sempre é absolutamente livre o exercício da Odontologia, há momentos em que se pode exigir do cirurgião-dentista uma obrigação de assistência $^{23}$. Temos como exemplo o Inciso VII do Artigo $7^{\circ}$ do $\mathrm{CEO}^{14}$, que diz que constitui infração ética, deixar de atender qualquer paciente que procure cuidados profissionais em caso de urgência, principalmente, quando não haja outro cirurgião-dentista em condições de fazê-lo.

Entretanto, o Artigo $3^{\circ}$, Inciso $\mathrm{V}$, do mesmo código ${ }^{14}$, onde trata-se dos direitos fundamentais dos profissionais inscritos, diz:

" $V$ - direito de renunciar ao atendimento do paciente, durante o tratamento, quando da constatação de fatos que, a critério do profissional, prejudiquem o bom relacionamento com o paciente ou o pleno desempenho profissional. Nestes casos tem o profissional o dever de comunicar previamente ao paciente ou seu responsável legal, assegurando-se da continuidade do tratamento e fornecendo todas as informações necessárias ao cirurgião-dentista que Ihe suceder" (ANEXO 8 - pág. 91).

Baseado nisso, uma das questões (questão 4 do ANEXO 3, e questão 7 do ANEXO 4) perguntava se o cirurgião-dentista tem direito de desistir do atendimento do paciente durante o tratamento. E complementar a esta, a questão seguinte propunha três situações como motivo para o cirurgiãodentista renunciar a este atendimento, devendo ser observado o Código de Ética Odontológica. 
Os resultados apresentados, demonstram que uma boa parte dos participantes, aproximadamente 31\%, que assinalaram "NÃO" ou deixaram em branco esta questão, desconhecem esse direito dos profissionais inscritos.

Discorrendo sobre o assunto, MANTECCA ${ }^{30}$, em 1998, afirma que, se após toda dedicação e tentativas de harmonização do desempenho, não existir mais um bom ambiente de trabalho no consultório, então deve o cirurgiãodentista encaminhar seu paciente para outro profissional através de uma carta de apresentação. E ainda no consultório odontológico confeccionar o documento de Cessação de Serviço, onde o cirurgião-dentista e paciente assinam consentido com o encerramento do tratamento.

SALES PERES et al. $^{42}, 2004$, chamam a atenção para o fato de que cabe ao profissional, além do disposto acima, conciliar o honorário profissional, ou seja, o custo para o paciente não deverá sofrer alterações, salvo se houver mudanças no plano de tratamento e anuência do paciente. Caso contrário, poder-se-á instalar um processo ético, desde que haja denúncia fundamentada por parte do paciente. Para tanto cita-se o Art. $7^{\circ}$, Inciso VI, que diz que constitui infração ética abandonar o paciente, salvo por um motivo justificável, circunstância em que deverão ser conciliados os honorários e indicado substituto".

Outra circunstância que coloca em pauta a questão de abandono ou recusa de atendimento, diz respeito a pacientes contaminados pelo vírus da AIDS. Embora não haja, nas normas éticas da Odontologia brasileira, referência explicita à questão HIVIAIDS, a discriminação tem se manifestado na recusa do atendimento sem que seja dada justificativa ao paciente ${ }^{38}$. 
Entretanto, este fato não se apresenta nos resultados desse trabalho, onde apenas um participante entendeu que seria seu direito, recusar-se a prestar serviços odontológicos quando, a qualquer momento, ficasse constatado que o paciente é portador de doença infecto contagiosa.

Existe uma grande discussão sobre o assunto, mas que não caberia aprofunda-la neste trabalho. Resumindo, temos que, grande parte dos autores $^{30,38,42}$, entende que, em situações de falta de condições técnicas, falta de formação adequada ou falta de preparo emocional do cirurgião-dentista, a ação do profissional poderá mais prejudicar do que ajudar o paciente. E, completando, SAMICO et al. ${ }^{45}$, 1994, afirmam que o cirurgião-dentista deve instruir e conscientizar o paciente quanto aos riscos e benefícios do tratamento, encaminhando-o a um serviço especializado, público ou privado.

\subsubsection{Do proprietário ou responsável técnico}

Todas as clínicas precisam ter um responsável técnico registrado como tal no Conselho Regional de Odontologia (CRO). Segundo LUCAS ${ }^{28}$, em 1999, caso não haja responsável técnico, se forem visitadas por um fiscal do CRO, o profissional que for encontrado trabalhando responderá pela mesma, tornandose responsável por qualquer tipo de infração cometida, já que o proprietário pode ser um leigo para odontologia, e, portanto, não responde a processo ético. Neste caso o profissional é visto como conivente em relação às irregularidades. 
Comprovando isto, o Artigo 22 do Código de Ética Odontológica ${ }^{14}$ deixa claro este aspecto, quando relata: "Os profissionais inscritos, quando proprietários, ou o responsável técnico responderão solidariamente com o infrator pelas infrações éticas cometidas".

Fato posto, outro quesito investigado foi com relação ao cirurgiãodentista inscrito no conselho, proprietário ou responsável técnico de clínica, se este responderia eticamente por erro de colega que atue sob sua responsabilidade.

Os resultados demonstraram um bom conhecimento dos participantes nesta questão, onde $89 \%$ deles entenderam que o proprietário ou responsável técnico responderia solidariamente com o colega infrator sob sua responsabilidade.

Entretanto, em muitos casos, por desconhecer as implicações jurídicas que pode enfrentar, o profissional surpreende-se ao ser processado por erro de colega sob sua responsabilidade. Um exemplo muito comum acontece em clínicas particulares e consultórios odontológicos, onde o proprietário, cirurgiãodentista, convida ou sede a clínica ou consultório para que outro colega realize algum tratamento, na maioria das vezes especializado, como: cirurgias, implante, etc. Contudo, este profissional (proprietário) desconhece que responderá eticamente caso o colega cometa alguma infração.

Além do exposto acima, SALES PERES et al. ${ }^{42}$, em 2004, lembram também, que o treinamento do pessoal auxiliar quanto aos aspectos éticos da prática odontológica fica a cargo do cirurgião-dentista, pois em caso de infração 
ética cometida por estes profissionais, o cirurgião-dentista responde conjuntamente no processo.

\subsubsection{Das infrações éticas}

Alguns dos artigos do Código de Ética Odontológica ${ }^{14}$, apontam em seus incisos o que constitui infração ética. Como exemplo, no Artigo $7^{\circ}$, Incisos de I a XII (pág. 93 do ANEXO 8), temos indicadas as situações do relacionamento com o paciente que constituem infrações éticas.

Para o profissional, este tipo de redação, poderia facilitar o entendimento dos aspectos éticos e antiéticos da odontologia, todavia, os resultados apresentados por este trabalho, demonstram um certo desconhecimento de algumas dessas situações abordadas pelo Código de Ética. Como exemplo, temos que, 38 dos 150 participantes, ou seja, aproximadamente 25\%, desconhecem que "receber ou dar gratificação, por encaminhamento de pacientes" constitui infração ética, segundo o Artigo 12, inciso III do Código de Ética Odontológica ${ }^{14}$ (pág. 95 do ANEXO 8).

Outro aspecto, que por vezes, causa dúvida nos profissionais, é com relação às exceções contidas no texto de alguns incisos. Exemplificando, temos que $36 \%$ dos participantes entenderam que "prestar atendimento de urgência ou emergência a menor de idade sem a prévia autorização dos responsáveis ou representantes legais", seria infração ética. 
Entretanto, o Inciso VIII do Artigo $7^{\circ}$ do Código de Ética Odontológica ${ }^{14}$ (pág. 93 do ANEXO 8), diz que constitui infração ética, iniciar o atendimento de um menor de idade, sem a autorização de seus responsáveis ou representantes legais, exceto em casos de urgência ou emergência.

7.2.5 Dos profissionais a quem se aplica o Código de Ética Odontológica

No Capítulo I do Código de Ética Odontológica ${ }^{14}$, referente às disposições preliminares, o artigo $1^{\circ}$ em seu parágrafo único diz:

"As normas éticas deste Código devem ser seguidas pelos cirurgiões-dentistas, pelos profissionais de outras categorias auxiliares reconhecidas pelo CFO, independentemente da função ou cargo que ocupem, bem como pelas pessoas jurídicas." (ANEXO 8 - pág.91)

A última pergunta abordava justamente este tema, onde questionava-se a quais profissionais se aplica o Código de Ética Odontológica. Dentre os participantes, apenas $40 \%$ entenderam que, além do cirurgião-dentista, os outros profissionais de categorias auxiliares, também se enquadram nas normas éticas desse Código. Uma boa parcela dos participantes, 31\%, entenderam que somente ao cirurgião-dentista se aplicam as normas do Código de Ética, e outros 21\%, somaram a este, apenas o auxiliar de consultório dentário e o técnico em higiene dental. 
No entanto, como lembra LUCATO $^{29}$, em 2005, o atual Código de Ética Odontológica, visa alcançar todos os cirurgiões-dentistas, técnicos em higiene dental, atendentes de consultório odontológico, técnicos em prótese dental e auxiliares de prótese dental, tentando fazer com que eles promovam a repersonalização de seus serviços.

Discordando neste aspecto, SALES PERES et al. ${ }^{42}$, em 2004, lamentam a generalização do todo, haja vista que não se pode atribuir responsabilidades igualitárias ao contemplar funções dispares.

Fato posto, torna-se importante salientar, os riscos inerentes ao desconhecimento do tema, pois como mencionado anteriormente, o treinamento do pessoal auxiliar quanto aos aspectos éticos da prática odontológica fica a cargo do cirurgião-dentista, e em caso de infração ética cometida por estes profissionais, sob sua responsabilidade, levarão o cirurgiãodentista a responder conjuntamente no processo ético.

\subsection{Pontuação e comparação dos grupos}

SAMICO ${ }^{44}$, em 1994, enfatiza que o estudante universitário, desde cedo, deve aceitar e defender o cumprimento das normas previstas no Código de Ética Odontológica. Para ele, é necessário que desde logo, o acadêmico esteja dominando não apenas a técnica, mas também, já tenha uma razoável formação ética especial, o que lhe permitirá agir sempre com maior acerto. 
Frente aos resultados deste trabalho, este grupo, composto por futuros profissionais odontólogos, apesar de apresentar um melhor nível de conhecimento do Código de Ética Odontológica quando comparado com os grupos dos profissionais já formados, demonstrou uma certa deficiência quanto a este conhecimento, onde, após a pontuação dos questionários, numa escala de zero a dez, obtive uma nota média de 6,40.

De encontro a isto, GARBIN et al. $^{24}$, em 2002, afirmam que o grande número de Faculdades de Odontologia e o distanciamento dos cursos da realidade social promovem a formação de profissionais com uma visão humanista limitada, além de valorizar a técnica em demasia e não levar em conta a preparação do aluno para interação com seus futuros pacientes. Após analisar a postura dos alunos do $4^{\circ}$ ano da Faculdade de Odontologia de Araçatuba/SP - UNESP sobre a conscientização da ética em ciências de saúde e o interesse desses acadêmicos pelo tema, os autores concluíram que, apesar de toda evolução de informações, ainda existem profissionais que consideram-se despreparados eticamente para atender seus pacientes.

Assim, para a grande maioria dos autores que discorrem sobre o assunto $^{24,25,26 \text { e } 33}$, existe a necessidade de uma maior carga horária, destinada ao ensinamento das questões éticas e legais no currículo dos cursos de graduação em Odontologia, pois atualmente, o tempo destinado a estes assuntos é, comprovadamente, insuficiente.

Passando para os grupos dos profissionais já formados (GRUPOS II e III), vemos que estes apresentam uma maior deficiência quanto ao conhecimento dos aspectos éticos da Odontologia, quando comparados com o 
grupo anterior (acadêmicos). Entretanto, a nota média de 6,04 dos profissionais clínicos que cursam especialização (GRUPO III), não obteve diferença estatisticamente significante quando comparada à nota dos acadêmicos (GRUPO I). Já a nota média de 5,08 dos profissionais exclusivamente clínicos (GRUPO II), apresentou diferença estatisticamente significante quando comparada à nota dos outros dois grupos.

Estes resultados, podem estar relacionados ao isolamento destes cirurgiões-dentistas, unicamente clínicos, em seus consultórios, onde, a falta da educação permanente, afasta cada vez mais estes profissionais, não apenas da evolução científica e tecnológica da Odontologia, mas principalmente, do avanço e aprimoramento das relações éticas e humanistas por que passam as profissões da saúde.

De acordo com isso, GARBIN et al. ${ }^{24}$, em 2002, afirmam, que é evidente a necessidade de um maior preparo do cirurgião-dentista no que diz respeito aos aspectos éticos e legais de sua profissão, e concluem dizendo, que é importante que estas discussões não fiquem restritas ao âmbito acadêmico, devendo os profissionais se capacitarem continuamente para a superação de suas limitações, através de aperfeiçoamentos e atualizações, pois o compromisso ético dos profissionais pode ser desenvolvido em qualquer etapa da vida humana.

Aos órgãos disciplinadores da ética profissional compete, a tarefa implícita de fiscalizar o comportamento ético dos que integram a categoria. Contudo, mais importante que a atuação punitiva, cabe-lhes a missão 
preventiva, através de divulgação constante de normas e padrões éticos em publicações especializadas, reuniões e cursos periodicamente oferecidos ${ }^{33}$.

Concordando com isto, GAUDENZI ${ }^{25}$, em 2004, afirma que, os Conselhos profissionais, que exercem a vigilância do cumprimento do código de ética de cada categoria, têm importante papel na defesa dos interesses do profissional e da profissão, mas também em programas de educação continuada que visem promover o constante aperfeiçoamento técnico e ético desses profissionais. 


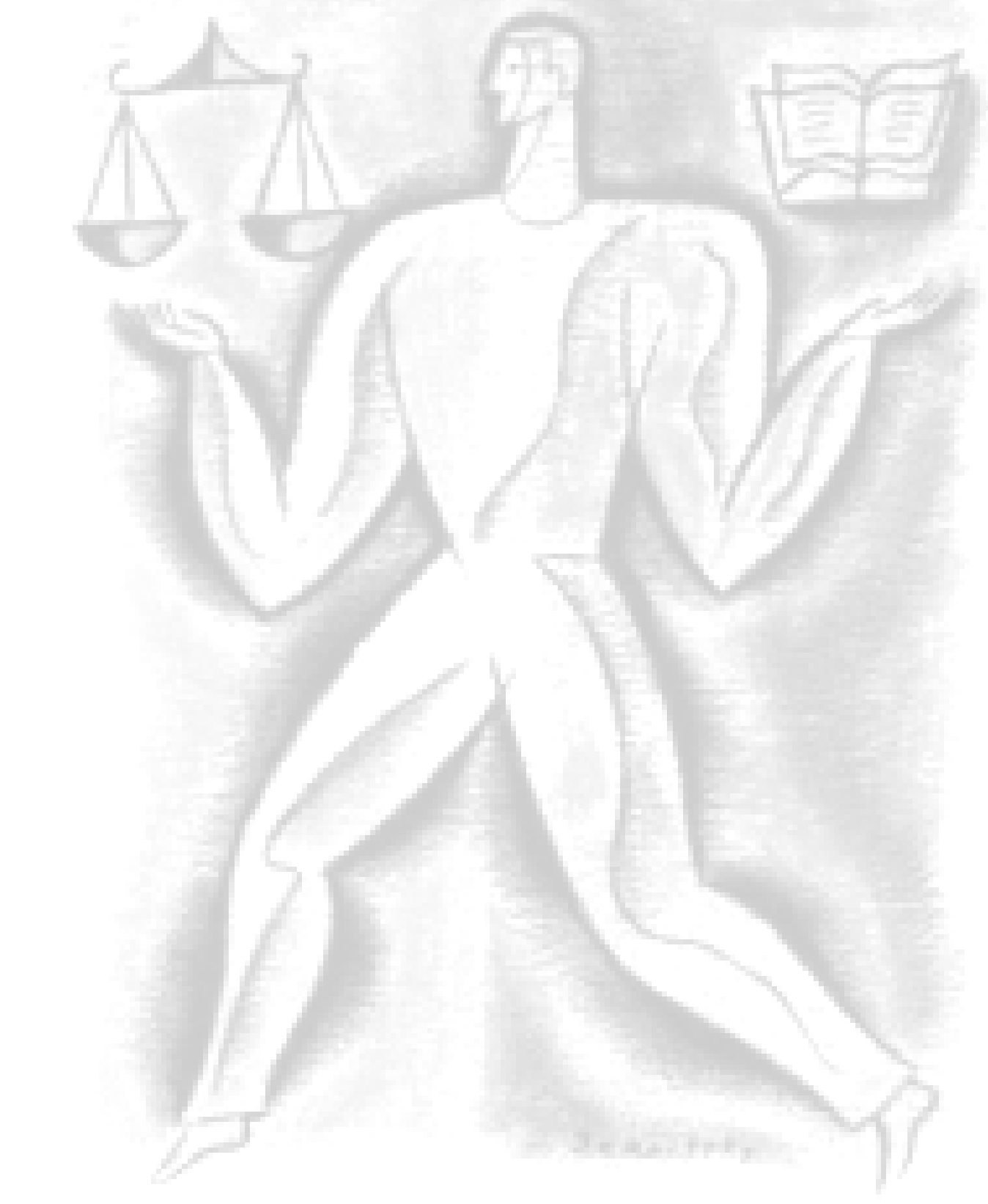

CONCLUSÕES 


\section{CONCLUSÕES}

Após a análise dos resultados deste estudo pode-se concluir que:

1. Existe deficiência quanto ao conhecimento de alguns artigos do Código de Ética Odontológica, tanto dos acadêmicos do último ano de graduação em Odontologia, como dos profissionais já formados.

2. Os profissionais cirurgiões-dentistas que atuam exclusivamente em consultórios ou clínicas, quando comparados aos profissionais que cursam especialização, e com os acadêmicos do último ano de graduação, apresentam um maior desconhecimento referente às questões éticas que envolvem a odontologia.

3. Faz-se necessária, a maior divulgação possível do Código de Ética Odontológica, principalmente àqueles profissionais exclusivamente clínicos, sendo imprescindível o empenho máximo do Conselho Federal e dos Conselhos Regionais de Odontologia, além dos docentes da área e as entidades de classe, buscando preventivamente educar e instruir os profissionais, para evitar condenar e punir. 


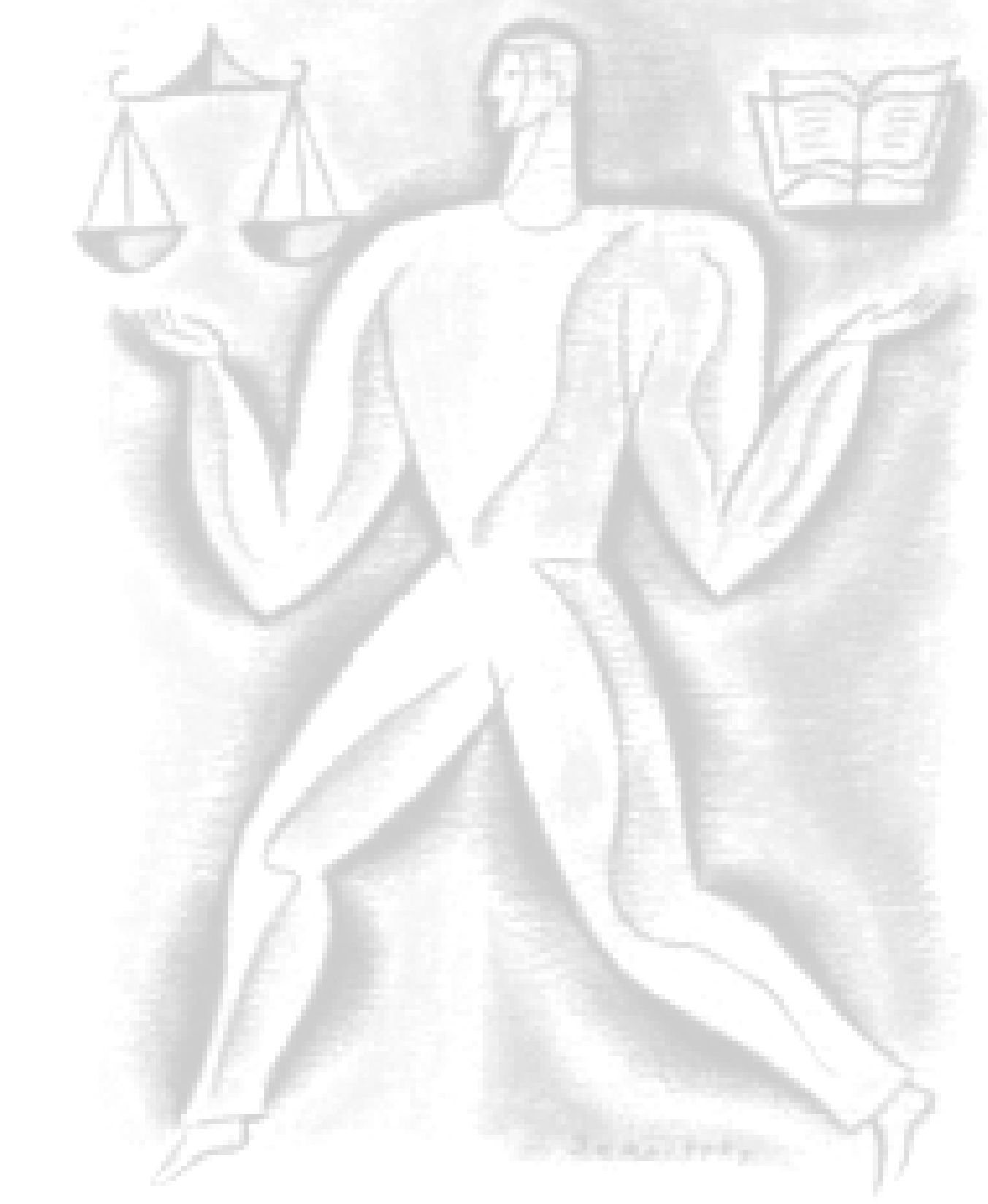

ANEXOS 


\section{ANEXO 1 - Ofício com o parecer do Comitê de Ética em Pesquisa em} Seres Humanos da FOB - USP.

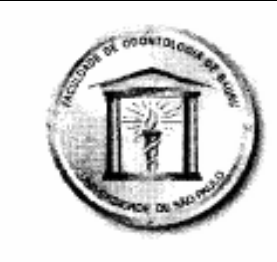

\section{Universidade de São Paulo Faculdade de Odontologia de Bauru}

A1. Dr. Octávio Pinheiro Brisolla, 9-75 - Bauru-SP - CEP 17012-901 - C.P. 73 PABX (0XX14)3235-8000 - FAX (0XX14)3223-4679

\section{Comitê de Ética em Pesquise}

Processo $n^{\circ}$ 27/2006

Bauru, 27 de abril de 2006.

Senhor Professor,

O projeto de pesquisa encaminhado a este Comitê de Ética em Pesquisa em Seres Humanos, denominado "Verificação do grau de conhecimento dos alunos dos cursos de especialização em odontologia do município de Bauru-SP sobre o Código de Ética Odontológica", de sua autoria e juntamente com Fernando Toledo de Oliveira e Sérgio Donha Yarid, que scrá desenvolvido sob sua orientação, foi enviado ao relator para avaliação.

Na reuniăo de 26 de abril de 2006 o parecer do relator, aprovando o projeto, foi aceito pelo Comitê, considerando que não existem infraçōes èticas pendentes.

Informamos que após o envio do trabalho concluido, este Comitê enviará o parecer final, que será utilizado para publicação do trabalho.

Atenciosamente,

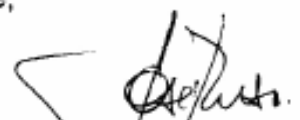

Prof. Dr. José Honnique Rubo Coordenador

$\| m^{\circ}$ Sr. Prof. Dr. Arsênio Sales Peres

DD. Docente do Departamento de Odontopediatria, Ortodontia e Saúde Coletiva 
ANEXO 2 - Ofício do Comitê de Ética autorizando a alteração do titulo do trabalho.

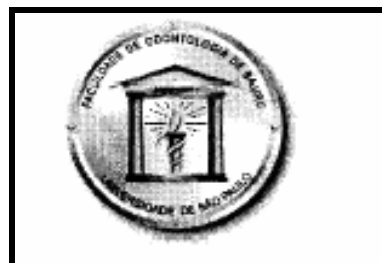

\section{Universidade de São Paulo \\ Faculdade de Odontologia de Bauru}

Al. Dr. Octávio Pinheiro Brisolla, 9-75 - Bauru-SP - Brasil - CEP 17012-901 - C.P. 73 PABX (0XX14)3235-8000 - FAX (0XX14)3223-4679

Comitê de Ética em Pesquisa (3235-8356)

Of.n ${ }^{\circ}$ CEP/18 2006/FOB

Proc. CEP n $27 / 2006$

Bauru, 20 de outubro de 2006.

Senhor Professor,

Informamos que após análise por este Comitê de Ética em Pesquisa em Seres Humanos, a alteração do título do projeto de pesquisa "Verificaçăo do grau de conhecimento dos alunos dos cursos de especialização em odontologia do município de Bauru-SP sobre o Código de Ética Odontológica" de sua autoria juntamente a Fernando Toledo de Oliveira e Sérgio Donha Yarid, sob sua orientação, para "Ética profissional odontológica: análise do conhecimento de discentes e cirurgiōes-dentistas, sobre o código deontológico da profissão" foi aprovado considerando que não houve modificação em sua metodologia.

Lembramos que após o envio do trabalho concluido, este Comitê enviará o parecer final, que será utilizado para a publicação do trabalho.

Atenciosamente,

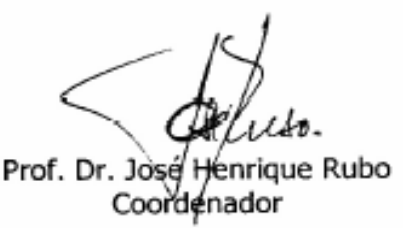

Prof. Dr. Arsênio Sales Peres

Docente do Departamento de Odontopediatria, Ortodóntia e Saúde Coletiva 
ANEXO 3 - Questionário aplicado aos acadêmicos do último ano de graduação em Odontologia das Universidades de Bauru-SP.

\begin{tabular}{|c|c|}
\hline \multicolumn{2}{|c|}{ Avaliação do grau de conhecimento do Código de Ética Odontológica. } \\
\hline \multicolumn{2}{|c|}{ POR FAVOR NÃO SE IDENTIFIQUE } \\
\hline $\begin{array}{l}\text { 1.A Universidade onde cursa graduação é: } \\
\begin{array}{ll}\text { ( ) Pública } & \text { ( ) Privada }\end{array} \\
\text { 2.Faixa etária em que se encontra? } \\
\begin{array}{ll}\text { ( ) } 18 \text { a } 24 \text { anos } & \text { ( ) } 25 \text { a } 30 \text { anos } \\
\text { ( ) } 31 \text { anos ou mais } & \end{array}\end{array}$ & $\begin{array}{l}\text { 6.Sendo o cirurgião-dentista, inscrito no } \\
\text { Conselho, proprietário ou responsável } \\
\text { técnico de clínica, responderá eticamente } \\
\text { por erro de colega que ali atue sob sua } \\
\text { responsabilidade? } \\
\begin{array}{ll}\text { ( ) Sim } & \text { ( ) Não }\end{array}\end{array}$ \\
\hline 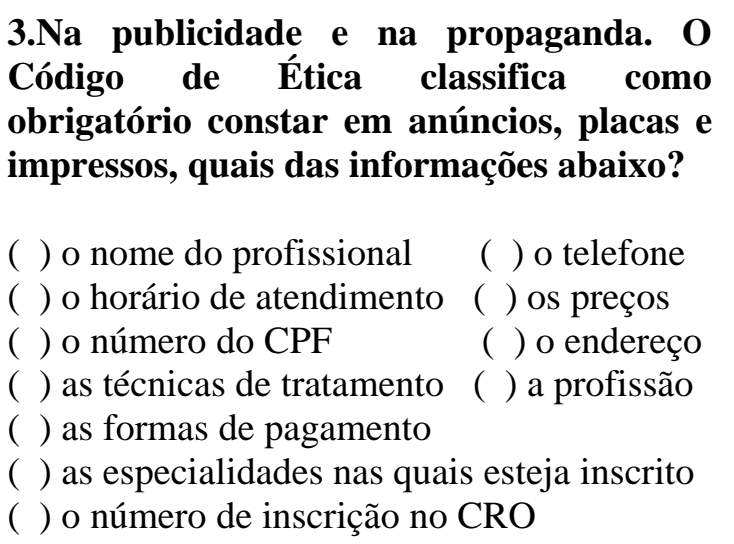 & $\begin{array}{l}\text { 7.Segundo o Código de Ética Odontológica } \\
\text { constitui(em) infração(ões) ética(s): } \\
\text { ( ) esclarecer os propósitos, riscos, custos e } \\
\text { as alternativas de tratamento. } \\
\text { ( ) prestar atendimento de urgência ou de } \\
\text { emergência a menor de idade sem a prévia } \\
\text { autorização dos responsáveis ou } \\
\text { representantes legais. } \\
\text { ( ) receber ou dar algum tipo de gratificação } \\
\text { a outro profissional, por encaminhamento de } \\
\text { pacientes. }\end{array}$ \\
\hline $\begin{array}{l}\text { 4.De acordo com o Código de Ética } \\
\text { Odontológica, o cirurgião dentista tem } \\
\text { direito de desistir do atendimento do } \\
\text { paciente durante o tratamento? } \\
\text { ( ) sim ( ) não } \\
\text { 5.Se a resposta anterior foi “sim”, em } \\
\text { qual(is) situação(ões) abaixo relacionada(s) } \\
\text { isso pode ocorrer? } \\
\text { ( ) quando, ao seu critério, o profissional } \\
\text { constate fatos que prejudiquem o bom } \\
\text { relacionamento com o paciente. } \\
\text { ( ) quando o profissional bem entender, } \\
\text { inclusive sem necessidade de justificativa. } \\
\text { ( ) quando, a qualquer momento, o } \\
\text { profissional constate que o paciente é } \\
\text { portador de doença infecto contagiosa. }\end{array}$ & $\begin{array}{l}\text { 8.0 Código de Ética Odontológica é } \\
\text { aplicado a qual(is) profissional(is)? } \\
\text { ( ) somente cirurgião-dentista. } \\
\text { ( ) cirurgião-dentista, auxiliar de consultório } \\
\text { dentário e técnico em higiene dental. } \\
\text { ( ) cirurgião-dentista e técnico de prótese } \\
\text { dentária. } \\
\text { ( ) cirurgião-dentista, auxiliar de consultório } \\
\text { dentário, técnico em higiene dental, técnico } \\
\text { de prótese dentária e auxiliar de prótese } \\
\text { dentária. }\end{array}$ \\
\hline
\end{tabular}




\section{ANEXO 4 - Questionário aplicado aos cirurgiões-dentistas clínicos e os} alunos de especialização do município de Bauru-SP.

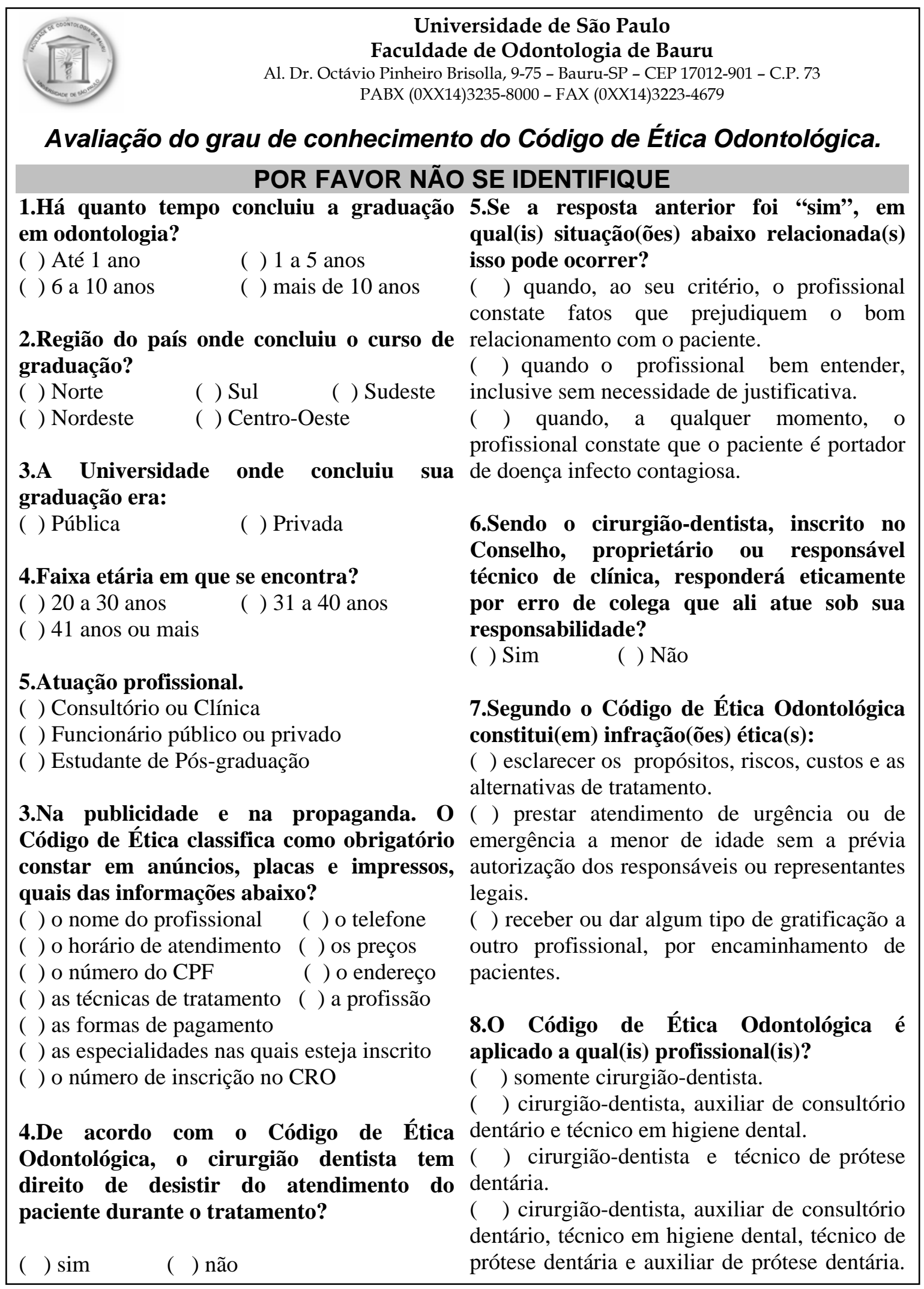


ANEXO 5 - Resposta via e-mail, do CRO-MG, com informação sobre os processos éticos contra cirurgiões-dentistas deste estado.

\begin{tabular}{|c|c|c|c|c|c|}
\hline \multicolumn{6}{|c|}{ Data: Thu, 13 Jul 2006 09:56:42 -0300 } \\
\hline \multicolumn{6}{|c|}{ De: Comissão de Ética <etica@cromg.org.br>4 } \\
\hline \multicolumn{6}{|c|}{ Para: fto@usp.bra } \\
\hline \multicolumn{6}{|c|}{ Assunto: Levantamento processo ético } \\
\hline \multicolumn{5}{|c|}{ Parte(s): 眘 2 Levantamentoetico.doc application/msword } & $\begin{array}{l}383.84 \\
K B\end{array}$ \\
\hline \multicolumn{6}{|c|}{ Prezado Fernando, anexo último levantamento. } \\
\hline \multicolumn{6}{|c|}{ CONSELHO REGI ONAL DE ODONTOLOGIA DE MI NAS GERAIS } \\
\hline \multicolumn{6}{|c|}{$\begin{array}{l}\text { Av. do Contorno, } 7556 \text { - BAIRRO LOURDES - TELEFONE: (031) 2104-3000 } \\
\text { CAIXA POSTAL } 1117 \text { - CEP 30110-048 - BELO HORIZONTE }\end{array}$} \\
\hline \multicolumn{6}{|c|}{ PROCESSOS ÉTICOS } \\
\hline \multicolumn{6}{|c|}{$\begin{array}{l}2000 \text { - } 83 \text { processos éticos - } 83 \text { julgados/arquivados } \\
2001 \text { - } 129 \text { processos éticos - } 107 \text { julgados/arquivados } \\
2002 \text { - } 89 \text { processos éticos - } 79 \text { julgados/arquivados } \\
2003 \text { - } 125 \text { processos éticos - } 69 \text { julgados/arquivados } \\
2004 \text { - } 113 \text { processos éticos - } 41 \text { julgados/arquivados }\end{array}$} \\
\hline MOTIVO & 2000 & 2001 & 2002 & 2003 & 2004 \\
\hline Denúncia pacientes (Clínica Geral-Endo) & 13 & 15 & 05 & 05 & 08 \\
\hline Denúncia pacientes (Ortodontia) & 06 & 13 & 09 & 03 & 09 \\
\hline Denúncia pacientes (Prótese Dentária) & 08 & 16 & 09 & 09 & 05 \\
\hline Denúncia pacientes (Cirurgia Traumat.) & 02 & 02 & 05 & 02 & - \\
\hline Denúncia pacientes (Perio/Prótese) & 01 & 01 & 02 & - & - \\
\hline Denúncia pacientes (Implante/Prótese) & 01 & 02 & 04 & 09 & 05 \\
\hline Denúncia pacientes (Periodontia) & 01 & 03 & 03 & 01 & 01 \\
\hline Propaganda e/ou clínica irregular & 36 & 65 & 50 & 71 & 70 \\
\hline CD inscrito em outro Regional & 13 & 04 & - & 09 & 10 \\
\hline TPD/THD/APD exercendo função CD & 03 & - & 07 & 05 & 03 \\
\hline $\mathrm{CD}$ contra $\mathrm{CD}$ ou outros profissionais & 02 & 05 & - & 09 & - \\
\hline
\end{tabular}




\section{ANEXO 6 - Resposta via e-mail, do CRO-ES, com informação sobre os processos éticos contra cirurgiões-dentistas deste estado.}

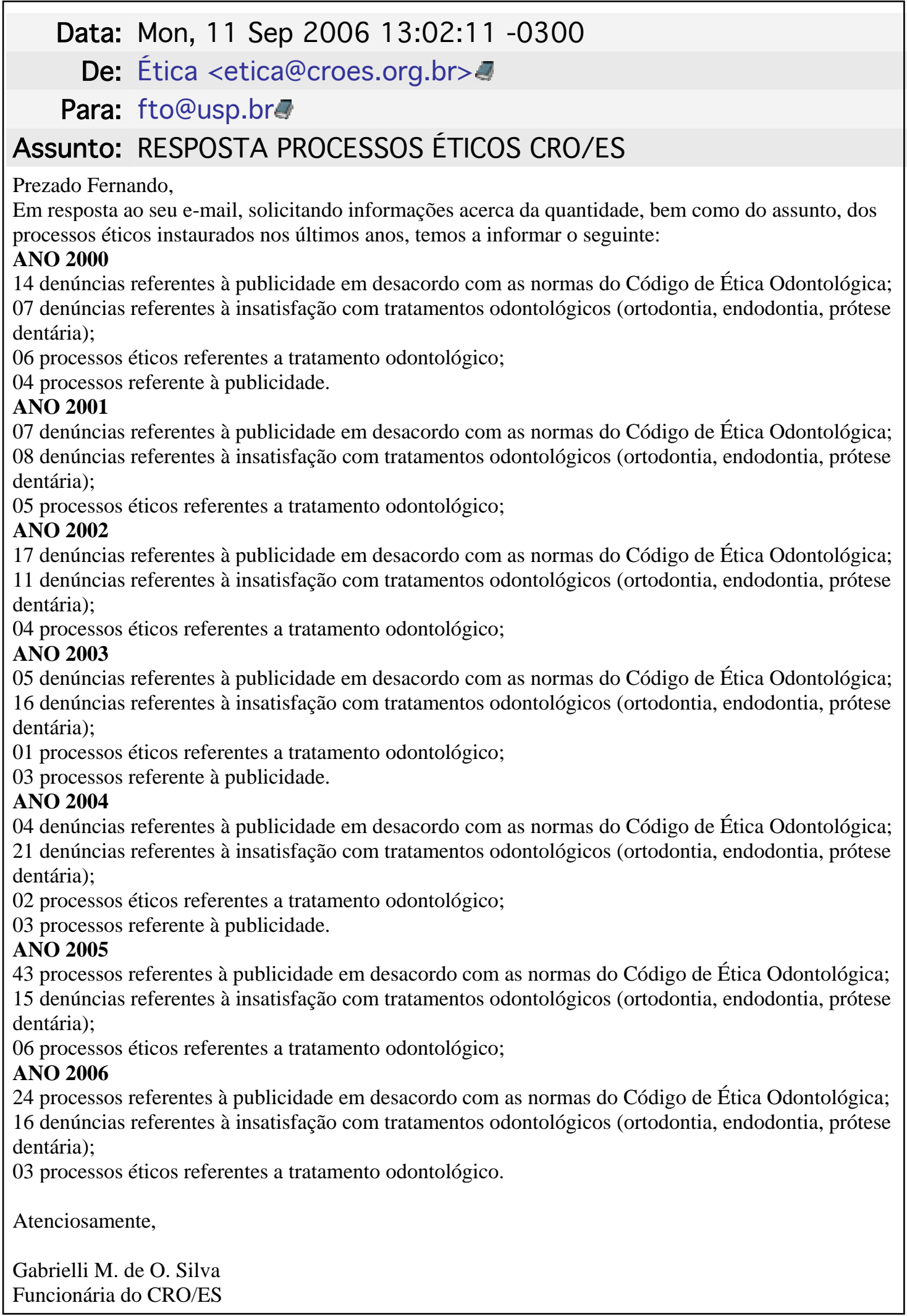


ANEXO 7 - Resposta via e-mail, do CRO-DF, com informação sobre os processos éticos contra cirurgiões-dentistas deste estado.

Data: Mon, 31 Jul 2006 15:42:36 -0300

De: CRO-DF <cro-df@cro-df.org.br>a

Para: fto@usp.bra

Assunto: Re: Solicitação de Informações

Parte(s): Gráfico - Comissão de Ética 2002 - 2004 e 2005 - 200 6.xls

Prezado Senhor,

Conforme solicitação de $\mathrm{V}$. $\mathrm{S}^{\mathrm{a}}$. segue anexa planilha com relatório da

Comissão de Ética.

Cordialmente,

Comissão de Ética - CRO-DF

Comparativo CRO-DF 2002/2004 e 2005/2006

\begin{tabular}{|l|c|c|c|c|c|}
\cline { 2 - 7 } & 2002 & 2003 & 2004 & 2005 & 2006 \\
\hline Processos & 20 & 29 & 34 & 79 & 38 \\
\hline Julgamentos & 15 & 22 & 28 & 52 & 22 \\
\hline Condenações & 10 & 17 & 19 & 30 & 14 \\
\hline Absolvições & 5 & 5 & 9 & 22 & 8 \\
\hline Prisões & 15 & 12 & 11 & 12 & 1 \\
\hline Termo de Ajustamento de Conduta & 0 & 0 & 0 & 32 & 22 \\
\hline
\end{tabular}

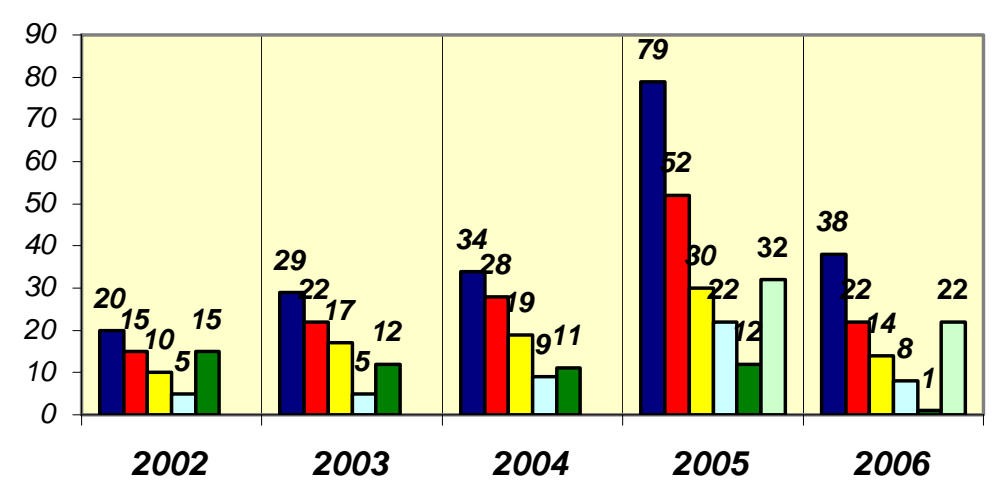

Processos 
ANEXO 8 - Código de Ética Odontológica. Aprovado pela Resolução CFO42, de 20 de maio de 2003.

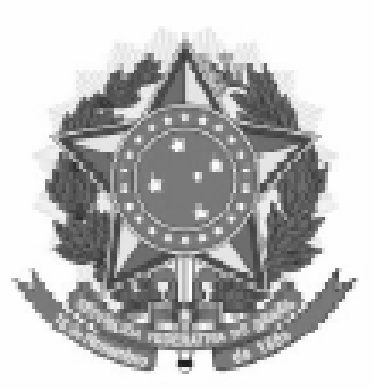

CONSELHO FEHEKAL IE OIDONTOLOGH

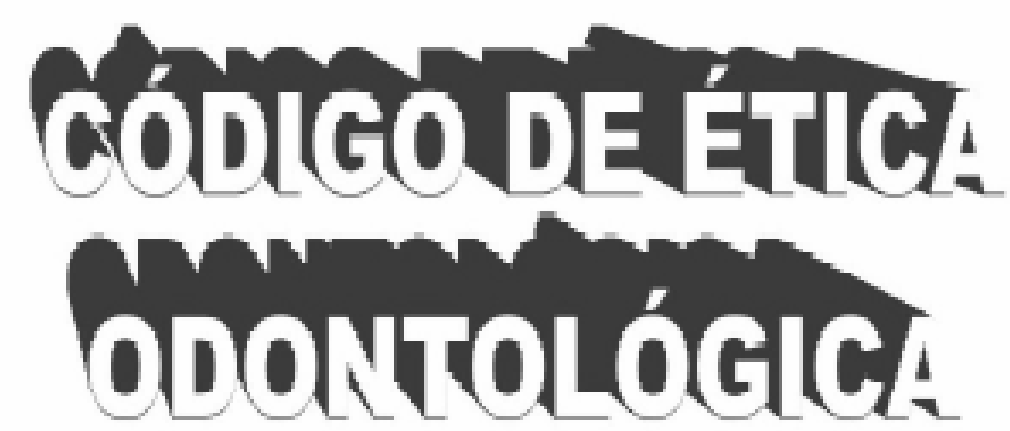

B2010:

\section{CÓDIGO DE ÉTICA ODONTOLÓGICA \\ (APROVADO PELA RESOLUÇÃO CFO-42, DE 20 DE MAIO DE 2003)}

Texto do Capitulo XIV alterado através da Resolução CFO-71, de 06 de junho de 2006, aprovada na CCIX Reunião Ordinária, de 25 de maio de 2006, referendou as decisões de CCVII Reunião Ordinária do Plenário do Conselho Federal de Odontologia - Assembléia Conjunta com os Conselhos Regionais de Odontologia, em Recife, nos dias 06 e 07 de abril de 2006. 


\section{CONSELHO FEDERAL DE ODONTOLOGIA}

\section{MEMBROS EFETIVOS}

Presidente:

Vice-Presidente:

Secretário-Geral: Tesoureiro:
Miquel Aluara Santiaga Nabre

Ailtan Stiaga Marilhas Madrigues

Marcas SLuis Maceda de Santana

Clester Pantes de Menezes

Emanuel Sbias de Cliveira e Silua

Tosé Mária Marais Mateus

Mária Ferrata Eaurinha Fitho

Raberta Eluard da Voiga Cavali

Rulens Carte Real de Carvalha

\section{MEMBROS SUPLENTES}

Anisia Maria Fialho Allala Alires

Benícia Paura Mesquita

Genésia Pessaa de Alluquerque Gúniar

Mildeberta Cardoira Slins

Targe das Passas Carrêa Calra

Tasé Allar Stemartini Penna

Tasé Ferreira Campas Salrinha

Claércia Villela Marras

clucimar de Sousa cheal
Manael Cleapalda Fitha

Maria Carmen de Araúja Mela Tardim

Maria Izalel de Sauza Aluila Ramas

Marluiz Nunes de Freitas

Messias C Jamlia de Mela

Rutilia Caldas Pessanha

Selene Machado Casta Guedes

Wilsan Carnoira Ramas

\section{CONSELHO FEDERAL DE ODONTOLOGIA}

Av. Nilo Peçanha, 50 - Conj. 2316

20020-100 - Rio de Janeiro - RJ

Tel.: (21) 2122-2200

Site: www.cfo.ora.br - E-mail: cfo@cfo.org.br 


\section{CONSELHO FEDERAL DE ODONTOLOGIA}

\section{6}

\section{SUMÁRIO}

Resolução CFO-42/2003, de 20/05/03, que revoga o Código de Ética Odontológica aprovado pela Resolução CFO-179/91, de $19 / 12 / 91$

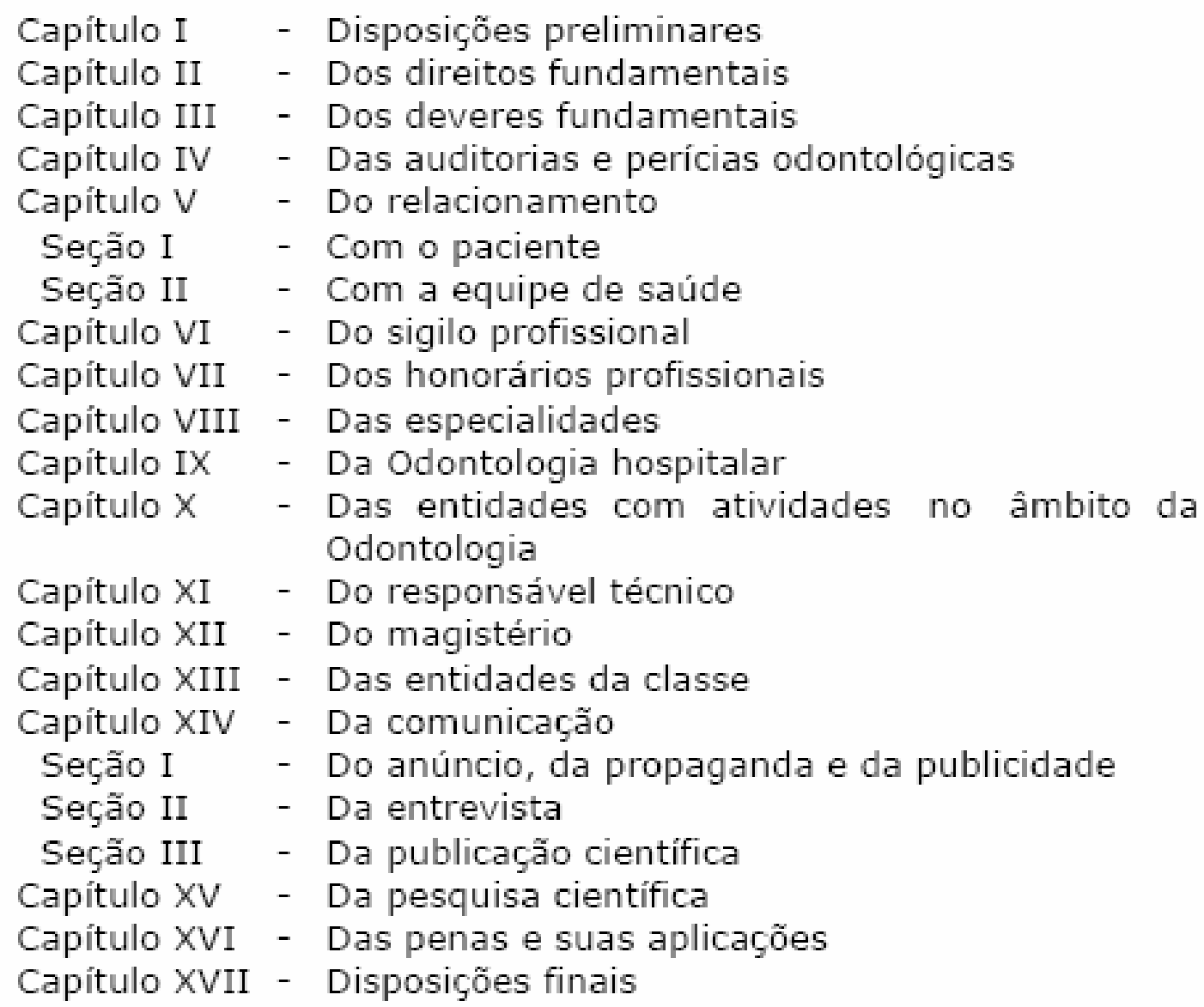




\title{
RESOLUÇÃO CFO-42/2003
}

\author{
Revoga o Código de Ética \\ Odontológica aprovado pela \\ Resolução CFO-179/91 e \\ aprova outro em substituição.
}

O Presidente do Conselho Federal de Odontologia, no exercício de suas atribuições regimentais, cumprindo deliberação do Plenário, em reunião realizada no dia 16 de maio de 2003, considerando o Relatório Final da III Conferência Nacional de Ética Odontológica - III CONEO, realizada em Florianópolis (SC), pelo Conselho Federal e Conselhos Regionais de Odontologia, em 14 de dezembro de 2002,

\section{RESOLVE:}

Art. $1^{\circ}$. Fica revogado o Código de Ética Odontológica, aprovado pela Resolução CFO-179, de 19 de dezembro de 1991.

Art. $2^{\circ}$. Fica aprovado o Código de Ética Odontológica, que com esta se publica.

Art. $3^{\circ}$. Esta Resolução entrará em vigor na data de sua publicação na Imprensa Oficial.

Rio de Janeiro, 20 de maio de 2003.

MARCO LUis MACEDO DE SANTANA, CD MIGUel ÁlVARO SANTIAGO NOBRE, CD SECRETÁRIO-GERAL

PRESIDENTE 


\section{CAPÍTULO I}

\section{DISPOSIÇÕES PRELIMINARES}

Art. $1^{\circ}$. O Código de Ética Odontológica regula os direitos e deveres dos profissionais, das entidades e das operadoras de planos de saúde, com inscrição nos Conselhos de Odontologia, segundo suas atribuições específicas.

Parágrafo único. As normas éticas deste Código devem ser seguidas pelos cirurgiõesdentistas, pelos profissionais de outras categorias auxiliares reconhecidas pelo CFO, independentemente da função ou cargo que ocupem, bem como pelas pessoas jurídicas.

Art. $2^{\circ}$. A Odontologia é uma profissão que se exerce, em benefício da saúde do ser humano e da coletividade, sem discriminação de qualquer forma ou pretexto.

\section{CAPÍTULO II}

\section{DOS DIREITOS FUNDAMENTAIS}

Art. $3^{\circ}$. Constituem direitos fundamentais dos profissionais inscritos, segundo suas atribuições específicas:

I - diagnosticar, planejar e executar tratamentos, com liberdade de conviç̧ão, nos limites de suas atribuições, observados o estado atual da ciência e sua dignidade profissional;

II - resguardar o segredo profissional;

III - contratar serviços profissionais de acordo com os preceitos deste Código;

IV - recusar-se a exercer a profissão em âmbito público ou privado onde as condições de trabalho não sejam dignas, seguras e salubres;

$\mathbf{V}$ - direito de renunciar ao atendimento do paciente, durante o tratamento, quando da constatação de fatos que, a critério do profissional, prejudiquem o bom relacionamento com o paciente ou o pleno desempenho profissional. Nestes casos tem o profissional o dever de comunicar previamente ao paciente ou seu responsável legal, assegurando-se da continuidade do tratamento e fornecendo todas as informações necessárias ao cirurgião-dentista que the suceder;

VI - recusar qualquer disposição estatutária ou regimental de instituição pública ou privada que limite a escolha dos meios a serem postos em prática para o estabelecimento do diagnóstico e para a execução do tratamento, salvo quando em benefício ou à livre escolha do paciente.

\section{CAPÍTULO III DOS DEVERES FUNDAMENTAIS}

Art. $4^{\circ}$. A fim de garantir o acatamento e cabal execução deste Código, cabe ao cirurgiãodentista e demais inscritos comunicar ao $\mathrm{CRO}$, com discrição e fundamento, fatos de que tenha conhecimento e caracterizem possível infringência do presente Código e das Normas que regulam o exercício da Odontologia.

Art. $5^{\circ}$. Constituem deveres fundamentais dos profissionais e entidades de Odontologia:

I - zelar e trabalhar pelo perfeito desempenho ético da Odontologia e pelo prestígio e bom conceito da profissão; 
II - assegurar as condições adequadas para o desempenho ético-profissional da Odontologia, quando investido em função de direção ou responsável técnico;

III - exercer a profissão mantendo comportamento digno;

IV - manter atualizados os conhecimentos profissionais, técnico-científicos e culturais, necessários ao pleno desempenho do exercício profissional;

V - zelar pela saúde e pela dignidade do paciente;

VI - guardar segredo profissional;

VII - promover a saúde coletiva no desempenho de suas funções, cargos e cidadania, independentemente de exercer a profissão no setor público ou privado;

VIII - elaborar e manter atualizados os prontuários de pacientes, conservando-os em arquivo próprio;

IX - apontar falhas nos regulamentos e nas normas das instituições em que trabalhe, quando as julgar indignas para o exercício da profissão ou prejudiciais ao paciente, devendo dirigir-se, nesses casos, aos órgãos competentes;

$\mathbf{X}$ - propugnar pela harmonia na classe;

XI - abster-se da prática de atos que impliquem mercantilização da Odontologia ou sua má conceituação;

XII - assumir responsabilidade pelos atos praticados;

XIII - resguardar sempre a privacidade do paciente;

XIV - não manter vínculo com entidade, empresas ou outros desígnios que os caracterizem como empregado, credenciado ou cooperado quando as mesmas se encontrarem em situação ilegal, irregular ou inidônea;

XV - comunicar aos Conselhos Regionais sobre atividades que caracterizem o exercício ilegal da Odontologia e que sejam de seu conhecimento;

XVI - garantir ao paciente ou seu responsável legal, acesso a seu prontuário, sempre que for expressamente solicitado, podendo conceder cópia do documento, mediante recibo de entrega;

XVII - registrar, os procedimentos técnico-laboratoriais efetuados, mantendo-os em arquivo próprio, quando técnico em prótese-dentária.

\section{CAPÍTULO IV \\ DAS AUDITORIAS E PERÍCIAS ODONTOLÓGICAS}

Art. $6^{\circ}$. Constitui infração ética:

I - deixar de atuar com absoluta isenção quando designado para servir como perito ou auditor, assim como ultrapassar os limites de suas atribuições e de sua competência;

II - intervir, quando na qualidade de perito ou auditor, nos atos de outro profissional, ou fazer qualquer apreciação na presença do examinado, reservando suas observações, sempre fundamentadas, para o relatório sigiloso e lacrado, que deve ser encaminhado a quem de direito;

III - acumular as funções de perito/auditor e procedimentos terapêuticos odontológicos na mesma entidade prestadora de serviços odontológicos; 
IV - prestar serviços de auditoria a empresas não inscritas no CRO da jurisdição em que estiver exercendo suas atividades.

\section{CAPÍTULO V \\ DO RELACIONAMENTO}

\section{SEÇÃO I \\ COM O PACIENTE}

Art. $7^{\circ}$. Constitui infração ética:

I - discriminar o ser humano de qualquer forma ou sob qualquer pretexto;

II - aproveitar-se de situações decorrentes da relação profissional/paciente para obter vantagem física, emocional, financeira ou política;

III - exagerar em diagnóstico, prognóstico ou terapêutica; tratamento;

IV - deixar de esclarecer adequadamente os propósitos, riscos, custos e alternativas do

V - executar ou propor tratamento desnecessário ou para o qual não esteja capacitado;

VI - abandonar paciente, salvo por motivo justificável, circunstância em que serão conciliados os honorários e indicado substituto;

VII - deixar de atender paciente que procure cuidados profissionais em caso de urgência, quando não haja outro cirurgião-dentista em condições de fazê-lo;

VIII - iniciar tratamento de menores sem a autorização de seus responsáveis ou representantes legais, exceto em casos de urgência ou emergência;

IX - desrespeitar ou permitir que seja desrespeitado o paciente;

$X$ - adotar novas técnicas ou materiais que não tenham efetiva comprovação científica;

XI - fornecer atestado que não corresponda à veracidade dos fatos ou dos quais não tenha participado;

XII - iniciar qualquer procedimento ou tratamento odontológico sem o consentimento prévio do paciente ou do seu responsável legal, exceto em casos de urgência ou emergência.

\section{SEÇÃO II COM A EQUIPE DE SAÚDE}

Art. $\mathbf{8}^{\circ}$. No relacionamento entre os membros da equipe de saúde serão mantidos o respeito, a lealdade e a colaboração técnico-científica.

Art. $9^{\circ}$. Constitui infração ética:

I - desviar paciente de colega;

II - assumir emprego ou função sucedendo o profissional demitido ou afastado em represália por atitude de defesa de movimento legítimo da categoria ou da aplicação deste Código;

III - praticar ou permitir que se pratique concorrência desleal; 
IV - ser conivente em erros técnicos ou infrações éticas, ou com o exercício irregular ou ilegal da Odontologia;

V - negar, injustificadamente, colaboração técnica de emergência ou serviços profissionais a colega;

VI - criticar erro técnico-científico de colega ausente, salvo por meio de representação ao Conselho Regional;

VII - explorar colega nas relações de emprego ou quando compartilhar honorários;

VIII - ceder consultório ou laboratório, sem a observância da legislação pertinente;

IX - utilizar-se de serviços prestados por profissionais não habilitados legalmente ou por profissionais da área odontológica, não regularmente inscritos no Conselho Regional de sua jurisdição.

\section{CAPÍTULO VI DO SIGILO PROFISSIONAL}

Art. 10. Constitui infração ética:

I - revelar, sem justa causa, fato sigiloso de que tenha conhecimento em razão do exercício de sua profissão;

II - negligenciar na orientação de seus colaboradores quanto ao sigilo profissional;

III - fazer referência a casos clínicos identificáveis, exibir pacientes ou seus retratos em anúncios profissionais ou na divulgação de assuntos odontológicos em programas de rádio, televisão ou cinema, e em artigos, entrevistas ou reportagens em jornais, revistas ou outras publicações legais, salvo se autorizado pelo paciente ou responsável;

$\S 1^{\circ}$. Compreende-se como justa causa, principalmente:
a) notificação compulsória de doença;
b) colaboração com a justiça nos casos previstos em lei;
c) perícia odontológica nos seus exatos limites;
d) estrita defesa de interesse legítimo dos profissionais inscritos;
e) revelação de fato sigiloso ao responsável pelo incapaz.

§2. Não constitui quebra de sigilo profissional a declinação do tratamento empreendido, na cobrança judicial de honorários profissionais.

\section{CAPÍTULO VII DOS HONORÁRIOS PROFISSIONAIS}

Art. 11. Na fixação dos honorários profissionais, serão considerados:

I - a condição sócio-econômica do paciente e da comunidade;

II - o conceito do profissional;

III - o costume do lugar;

IV - a complexidade do caso;

V - o tempo utilizado no atendimento;

VI - o caráter de permanência, temporariedade ou eventualidade do trabalho; 
VII - a circunstância em que tenha sido prestado o tratamento;

VIII - a cooperação do paciente durante o tratamento;

IX - o custo operacional.

Art. 12. Constitui infração ética: natureza;

I - oferecer serviços gratuitos a quem possa remunerá-los adequadamente;

II - oferecer seus serviços profissionais como prêmio em concurso de qualquer

III - receber ou dar gratificação por encaminhamento de paciente;

IV - instituir cobrança através de procedimento mercantilista;

V - abusar da confiança do paciente submetendo-o a tratamento de custo inesperado; públicas;

VI - receber ou cobrar honorários complementares de paciente atendido em instituições

VII - receber ou cobrar remuneração adicional de paciente atendido sob convênio ou contrato;

VIII - agenciar, aliciar ou desviar, por qualquer meio, paciente de instituição pública ou privada, para clínica particular.

Art. 13. O cirurgião-dentista deve evitar o aviltamento, ou submeter-se a tal situação inclusive por parte de convênios e credenciamentos, de valores dos serviços profissionais, não os fixando de forma irrisória ou inferior aos valores referenciais para procedimentos odontológicos.

\section{CAPÍTULO VIII DAS ESPECIALIDADES}

Art. 14. O exercício e o anúncio das especialidades em Odontologia obedecerão ao disposto neste capítulo e às normas do Conselho Federal.

Art. 15. O especialista, atendendo a paciente encaminhado por cirurgião-dentista, atuará somente na área de sua especialidade.

Parágrafo único. Após o atendimento, o paciente será, com os informes pertinentes, restituído ao cirurgião-dentista que o encaminhou.

Art. 16. É vedado intitular-se especialista sem inscrição da especialidade no Conselho Regional.

Art. 17. Para fins de diagnóstico e tratamento o especialista poderá conferenciar com outros profissionais.

\section{CAPÍTULO IX \\ DA ODONTOLOGIA HOSPITALAR}

Art. 18. Compete ao cirurgião-dentista internar e assistir paciente em hospitais públicos e privados, com e sem caráter filantrópico, respeitadas as normas técnico-administrativas das instituições.

Art. 19. As atividades odontológicas exercidas em hospital obedecerão às normas do Conselho Federal. 
Art. 20. Constitui infração ética, mesmo em ambiente hospitalar, executar intervenção cirúrgica fora do âmbito da Odontologia.

\section{CAPÍTULO X DAS ENTIDADES COM ATIVIDADES NO ÂMBITO DA ODONTOLOGIA}

Art. 21. Aplicam-se as disposições deste Código de Ética e as normas dos Conselhos de Odontologia a todos aqueles que exerçam a Odontologia, ainda que de forma indireta, sejam pessoas físicas ou jurídicas, clínicas, policlínicas, cooperativas, planos de assistência à saúde, convênios de qualquer forma, credenciamento, administradoras, intermediadoras, seguradoras de saúde, ou quaisquer outras entidades.

Art. 22. Os profissionais inscritos, quando proprietários, ou o responsável técnico responderão solidariamente com o infrator pelas infrações éticas cometidas.

Art. 23. As entidades mencionadas no artigo 21 ficam obrigadas a:

I - indicar um responsável técnico de acordo com as normas do Conselho Federal, bem como respeitar as orientações éticas fornecidas pelo mesmo;

II - manter a qualidade técnico-científica dos trabalhos realizados;

III - propiciar ao profissional condições adequadas de instalações, recursos materiais, humanos e tecnológicos definidas pelo Conselho Federal de Odontologia, as quais garantam o seu desempenho pleno e seguro, exceto em condições de emergência ou iminente perigo de vida;

IV - manter auditorias odontológicas constantes, através de profissionais capacitados;

V - restringir-se à elaboração de planos ou programas de saúde bucal que tenham respaldo técnico, administrativo e financeiro;

VI - manter os usuários informados sobre os recursos disponíveis para atendê-los.

Art. 24. Constitui infração ética: congêneres;

I - apregoar vantagens irreais visando a estabelecer concorrência com entidades

II - oferecer tratamento abaixo dos padrões de qualidade recomendáveis; aliciamento;

III - executar e anunciar trabalho gratuito ou com desconto com finalidade de

IV - anunciar especialidades sem as respectivas inscrições de especialistas no Conselho Regional;

V - valer-se do poder econômico visando a estabelecer concorrência desleal com entidades congêneres ou profissionais individualmente;

VI - deixar de manter os usuários informados sobre os recursos disponíveis para o atendimento e de responder às reclamações dos mesmos;

VII - deixar de prestar os serviços ajustados no contrato;

VIII - oferecer serviços profissionais como prêmio em concurso de qualquer natureza;

IX - elaborar planos de tratamento para serem executados por terceiros;

$\mathbf{X}$ - prestar assistência e serviços odontológicos a empresas não inscritas nos Conselhos Regionais. 


\section{CAPÍTULO XI \\ DO RESPONSÁVEL TÉCNICO}

Art. 25. Ao responsável técnico cabe a fiscalização técnica e ética da empresa pela qual é responsável, devendo orientá-la, por escrito, inclusive sobre as técnicas de propaganda utilizadas.

Parágrafo único. É dever do responsável técnico primar pela fiel aplicação deste Código na entidade em que trabalha.

\section{CAPÍTULO XII \\ DO MAGISTÉRIO}

Art. 26. No exercício do magistério, o profissional inscrito exaltará os princípios éticos e promoverá a divulgação deste Código.

Art. 27. Constitui infração ética:

I - utilizar-se do paciente e/ou do aluno de forma abusiva em aula ou pesquisa;

II - eximir-se de responsabilidade nos trabalhos executados em pacientes pelos alunos;

III - utilizar-se da influência do cargo para aliciamento e/ou encaminhamento de pacientes para clínica particular;

IV - participar direta ou indiretamente da comercialização de órgãos e tecidos humanos;

V - utilizar-se de material didático de outrem, sem as devidas anuência e autorização.

Art. 28. Compete às entidades da classe, através de seu presidente, fazer as comunicações pertinentes que sejam de indiscutível interesse público.

Parágrafo único. Esta atribuição poderá ser delegada, sem prejuízo da responsabilidade solidária do titular.

Art. 29. Cabe ao presidente e ao infrator a responsabilidade pelas infrações éticas cometidas em nome da entidade.

Art. 30. Constitui infração ética:

I - servir-se da entidade para promoção própria, ou obtenção de vantagens pessoais;

II - prejudicar moral ou materialmente a entidade;

III - usar o nome da entidade para promoção de produtos comerciais sem que os mesmos tenham sido testados e comprovada sua eficácia na forma da Lei;

IV - desrespeitar entidade, injuriar ou difamar os seus diretores.

\section{CAPÍTULO XIV \\ DA COMUNICAÇÃO}

Art. 31. A comunicação e a divulgação em Odontologia obedecerão ao disposto neste Código.

$\S 1^{\circ}$. É vedado aos profissionais auxiliares, como os técnicos em prótese dentária, atendente de consultório dentário, técnico em higiene dental, auxiliar de prótese dentária, bem como aos laboratórios de prótese dentária fazer anúncios, propagandas ou publicidade dirigida ao público em geral. 
$\S 2^{\circ}$. Aos profissionais citados no $\S 1^{\circ}$ serão permitidas propagandas em revistas, jornais ou folhetos especializados, desde que dirigidas aos cirurgiões-dentistas, e acompanhadas do nome do profissional ou do laboratório, do seu responsável técnico e do número de inscrição no Conselho Regional de Odontologia.

\section{SEÇÃO I \\ DO ANÚNCIO, DA PROPAGANDA E DA PUBLICIDADE}

Art. 32. Os anúncios, a propaganda e a publicidade poderão ser feitos desde que obedecidos os preceitos deste Código como da veracidade, da decência, da respeitabilidade e da honestidade.

Art. 33. Na comunicação e divulgação é obrigatório constar o nome e o número de inscrição da pessoa física ou jurídica, bem como o nome representativo da profissão de cirurgião-dentista e também das demais profissões auxiliares regulamentadas. No caso de pessoas jurídicas, também o nome e o número de inscrição do responsável técnico.

\section{$\S 1^{\circ}$. Poderão ainda constar na comunicação e divulgação:}

I - áreas de atuação, procedimentos e técnicas de tratamento, desde que, precedidos do título da especialidade registrada no CRO ou qualificação profissional de clínico geral. Áreas de atuação são procedimentos pertinentes às especialidades reconhecidas pelo CFO;

II - as especialidades nas quais o cirurgião-dentista esteja inscrito no CRO; profissão;

III - os títulos de formação acadêmica 'stricto sensu' e do magistério relativos à

IV - endereço, telefone, fax, endereço eletrônico, horário de trabalho, convênios, credenciamentos e atendimento domiciliar;

V - logomarca e/ou logotipo; e,

VI - a expressão "CLíNICO GERAL", pelos profissionais que exerçam atividades pertinentes à Odontologia decorrentes de conhecimentos adquiridos em curso de graduação ou em cursos de pós-graduação.

$\S 2^{\circ}$. No caso de pessoa jurídica quando forem referidas ou ilustradas especialidades, deverão possuir a seu serviço profissional inscrito no CRO nas especialidades anunciadas, devendo, ainda, ser disponibilizada ao público a relação destes profissionais com suas qualificações, bem como os clínicos gerais com suas respectivas áreas de atuação, quando houver.

Art. 34. Constitui infração ética:

I - anunciar preços, serviços gratuitos e modalidades de pagamento, ou outras formas de comercialização que signifiquem competição desleal ou que contrariem o disposto neste Código;

II - Anunciar ou divulgar títulos, qualificações, especialidades que não possua ou que não seja reconhecida pelo CFO;

III - anunciar ou divulgar técnicas, terapias de tratamento, área de atuação, que não estejam devidamente comprovadas cientificamente, assim como instalações e equipamentos que não tenham seu registro validado pelos órgãos competentes;

IV - criticar técnicas utilizadas por outros profissionais como sendo inadequadas ou ultrapassadas;

V - dar consulta, diagnóstico ou prescrição de tratamento por meio de qualquer veículo de comunicação de massa, bem como permitir que sua participação na divulgação de assuntos odontológicos deixe de ter caráter exclusivo de esclarecimento e educação da coletividade; 
VI - divulgar nome, endereço ou qualquer outro elemento que identifique o paciente, a não ser com seu consentimento livre e esclarecido, ou de seu responsável legal, observadas as demais previsões deste Código e legislação pertinente;

VII - aliciar pacientes, praticando ou permitindo a oferta de serviços através de informação ou anúncio falso, irregular, ilícito ou imoral, com o intuito de atrair clientela, ou outros atos que caracterizem concorrência desleal ou aviltamento da profissão; odontologia;

VIII - induzir a opinião pública a acreditar que exista reserva de atuação clínica em

IX - divulgar ou permitir que sejam divulgadas publicamente observações desabonadoras sobre a atuação clínica ou qualquer manifestação negativa à atuação de outro profissional;

X - oferecer trabalho gratuito com intenção de autopromoção ou promover campanhas políticas oferecendo trocas de favores;

XI - anunciar serviços profissionais como prêmio em concurso de qualquer natureza, bem como oferecer prêmios pela utilização dos serviços prestados; do ambiente;

XII - provocar direta ou indiretamente, através de anúncio ou propaganda, a poluição

XIII - realizar propaganda de forma abusiva ou enganosa; e,

XIV - expor ao público leigo artifícios de propaganda, com o intuito de granjear clientela, especialmente a utilização de expressões antes e depois.

Art. 35. Caracteriza infração ética se beneficiar de propaganda irregular ou em desacordo com o previsto neste capítulo, ainda que aquele sujeito às Normas deste Código de Ética não tenha sido responsável direto pela veiculação da publicidade.

Art. 36. Aplicam-se, também, as normas deste Capítulo a todos aqueles que exerçam a Odontologia, ainda que de forma indireta, sejam pessoas físicas ou jurídicas, clínicas, policlínicas, operadoras de planos de assistência à saúde, convênios de qualquer forma, credenciamentos ou quaisquer outras entidades.

\section{SEÇÃO II \\ DA ENTREVISTA}

Art. 37. O profissional inscrito poderá utilizar-se de meios de comunicação para conceder entrevistas ou palestras públicas sobre assuntos odontológicos de sua atribuição, com finalidade de esclarecimento e educação no interesse da coletividade, sem que haja autopromoção ou sensacionalismo, preservando sempre o decoro da profissão.

\section{SEÇÃO III DA PUBLICAÇÃO CIENTÍFICA}

Art. 38. Constitui infração ética:

I - aproveitar-se de posição hierárquica para fazer constar seu nome na co-autoria de obra científica; publicada;

II - apresentar como sua, no todo ou em parte, obra científica de outrem, ainda que não

III - publicar, sem autorização por escrito, elemento que identifique o paciente preservando a sua privacidade; 
IV - utilizar-se, sem referência ao autor ou sem sua autorização expressa, de dados, informações ou opiniões coletadas em partes publicadas ou não de sua obra;

V - divulgar, fora do meio científico, processo de tratamento ou descoberta cujo valor ainda não esteja expressamente reconhecido cientificamente;

VI - falsear dados estatísticos ou deturpar sua interpretação; e,

VII - publicar pesquisa em animais e seres humanos sem submetê-la a avaliação prévia do comitê de ética e pesquisa em seres humanos e do comitê de ética e pesquisa em animais.

Art. $2^{\circ}$. Esta Resolução entrará em vigor na data de sua publicação na Imprensa Oficial, revogando-se as disposições em contrário.

\section{CAPÍTULO XV \\ DA PESQUISA CIENTÍFICA}

Art. 39. Constitui infração ética: saúde;

I - desatender às normas do órgão competente e à legislação sobre pesquisa em

II - utilizar-se de animais de experimentação sem objetivos claros e honestos de enriquecer os horizontes do conhecimento odontológico e, conseqüentemente, de ampliar os benefícios à sociedade;

III - desrespeitar as limitações legais da profissão nos casos de experiência in anima nobili;

IV - infringir a legislação que regula a utilização do cadáver para estudo e/ou exercícios de técnicas cirúrgicas;

V - infringir a legislação que regula os transplantes de órgãos e tecidos post-mortem e do "próprio corpo vivo";

VI - realizar pesquisa em ser humano sem que este ou seu responsável, ou representante legal, tenha dado consentimento, livre e esclarecido, por escrito, sobre a natureza das conseqüências da pesquisa;

VII - usar, experimentalmente, sem autorização da autoridade competente, e sem o conhecimento e o consentimento prévios do paciente ou de seu representante legal, qualquer tipo de terapêutica ainda não liberada para uso no país; instituições.

VIII - manipular dados da pesquisa em benefício próprio ou de empresas e/ou

\section{CAPÍTULO XVI}

\section{DAS PENAS E SUAS APLICAÇÕES}

Art. 40. Os preceitos deste Código são de observância obrigatória e sua violação sujeitará o infrator e quem, de qualquer modo, com ele concorrer para a infração, ainda que de forma omissa, às seguintes penas previstas no artigo 18 da Lei n. ${ }^{\circ}$ 4.324, de 14 de abril de 1964:

I - advertência confidencial, em aviso reservado;

II - censura confidencial, em aviso reservado;

III - censura pública, em publicação oficial;

IV - suspensão do exercício profissional até 30 (trinta) dias; 
V - cassação do exercício profissional ad referendum do Conselho Federal.

Art. 41. Salvo nos casos de manifesta gravidade e que exijam aplicação imediata de penalidade mais grave, a imposição das penas obedecerá à gradação do artigo anterior. Parágrafo único. Avalia-se a gravidade pela extensão do dano e por suas conseqüências.

Art. 42. Considera-se de manifesta gravidade, principalmente:

I - imputar a alguém conduta antiética de que o saiba inocente, dando causa a instauração de processo ético;

II - acobertar ou ensejar o exercício ilegal ou irregular da profissão;

III - exercer, após ter sido alertado, atividade odontológica em entidade ilegal, inidônea ou irregular;

IV - ocupar cargo cujo profissional dele tenha sido afastado por motivo de movimento classista; habilitado;

V - exercer ato privativo de cirurgião-dentista, sem estar para isso legalmente

VI - manter atividade profissional durante a vigência de penalidade suspensiva;

VII - praticar ou ensejar atividade indigna.

Art. 43. A alegação de ignorância ou a má compreensão dos preceitos deste Código não exime de penalidade o infrator.

Art. 44. São circunstâncias que podem atenuar a pena:

I - não ter sido antes condenado por infração ética;

II - ter reparado ou minorado o dano.

Art. 45. Além das penas disciplinares previstas, também poderá ser aplicada pena pecuniária a ser fixada pelo Conselho Regional, arbitrada entre 1 (uma) e 25 (vinte e cinco) vezes o valor da anuidade.

Parágrafo único. Em caso de reincidência, a pena de multa será aplicada em dobro.

\section{CAPÍTULO XVII DISPOSIÇÕES FINAIS}

Art. 46. O profissional condenado por infração ética a pena prevista no artigo 40 deste Código, poderá ser objeto de reabilitação, na forma prevista no Código de Processo Ético Odontológico.

Art. 47. As alterações deste Código são da competência exclusiva do Conselho Federal, ouvidos os Conselhos Regionais.

Art. 48. Este Código entrará em vigor, na data de sua publicação no Diário Oficial. 


\section{REFERÊNCIAS BIBLIOGRÁFICAS}




\section{REFERÊNCIAS BIBLIOGRÁFICAS*}

1. ALMEIDA, E. C. de S.; VENDÚSCULO, D. M. S.; MESTRINER JUNIOR, W. A conformação da odontologia enquanto profissão: uma revisão bibliográfica. Rev Bras Odontol, v.59, n.6, p.370-3, nov./dez. 2002.

2. AMORIM, A. G. Bioética e Odontologia: um perfil dos problemas éticos vividos por cirurgiões-dentistas. Rio Grande do Norte. 2005. 83 p. Dissertação (Mestrado) - Universidade Federal do Rio Grande do Norte.

3. BARCHIFONTAINE, C. P.; PESSINI, L. Fundamentos da bioética. São Paulo, Paulus, 1996.

4. BRASIL. Lei $\mathbf{n}^{\circ}$ 1.314: Regulamenta o exercício profissional dos cirurgiõesdentistas. 17 jan. 1951.

5. BRASIL. Lei $\mathbf{n}^{\circ}$ 4324: Institui o Conselho Federal e os Conselhos Regionais de Odontologia e dá outras providências. 14 de abril de 1964.

6. BRASIL. Lei $\mathbf{n}^{\circ}$ 5081: Regula o exercício da odontologia. 24 de agosto de 1966.

7. BRASIL. Parecer CNEICES n 1300, aprovado em 6 de novembro de 2001. Diretrizes Curriculares Nacionais dos cursos de graduação em Farmácia e Odontologia. Disponível em: http://portal.mec.gov.br. Acesso em 09/2006.

\footnotetext{
* Normas recomendadas para uso no âmbito da Universidade de São Paulo, com base no documento "Referências bibliográficas: exemplos", emanados do Conselho Supervisor do Sistema Integrado de Bibliotecas da USP, em reunião de 20 de setembro de 1990.
} 
8. BRASIL. Portaria $n^{\circ}$ 101: instruções reguladoras da lei $n^{0} 1.314$ de 17 de janeiro de 1951, que rege o exercício da odontologia. 28 jun. 1951.

9. CALVIELLI, I. T. P. A reforma do código de ética odontológica e outras considerações. Odontol - USF., v. 9, n. 1-2, p. 21-36, 1991.

10. CALVIELLI, I. T. P. Exercício ilícito da odontologia. In: SILVA, M. Compêndio de odontologia legal. Rio de Janeiro, Medsi, 1997. p.3949.

11. CALVIELLI, I. T. P. O exercício ilegal da odontologia, no Brasil. São Paulo, 1993. Dissertação (Mestrado) - Faculdade de Direito, Universidade de São Paulo.

12. CONSELHO FEDERAL DE ODONTOLOGIA. Dados do CFO. Disponível em: http://www.cfo.org.br. Acesso em 09/2006.

13. CONSELHO FEDERAL DE ODONTOLOGIA. Resolução CFO-179/91: Revoga o Código de Ética Odontológica aprovado pela Resolução CFO151, de 16 de julho de 1983 e aprova outro em substituição. 19.12.91. Rio de Janeiro: CFO; 1991.

14. CONSELHO FEDERAL DE ODONTOLOGIA. Resolução CFO-42/2003: Revoga o Código de Ética Odontológica aprovado pela Resolução CFO179/91 e aprova outro em substituição. Rio de Janeiro. 20 de maio de 2003. 
15. CONSELHO FEDERAL DE ODONTOLOGIA. Resolução CFO-59/2004: Revoga o Código de Processo Ético Odontológico aprovado pela Resolução CFO-183, de 1/10/1992 e aprova outro em substituição. 06 de outubro de 2004.

16. CONSELHO FEDERAL DE ODONTOLOGIA. Resolução CFO-71/2006: Altera o texto do Capítulo XIV do Código de Ética Odontológica. 06 de junho de 2006.

17. CUNHA, E. M. S. História da odontologia no Brasil. $2^{\mathrm{a}}$ ed. Rio de Janeiro, Editora Científica, 1952, 288p.

18. D'ASSUMPÇÃO, E. A. Comportar-se fazendo bioética para quem se interessa pela ética. Petrópolis, Vozez, 1998.

19. DUSILEK, D. Os desafios contemporâneos da bioética. Disponível em: http://www.unigranrio.br/comitebioteca.doc. Acesso em 06/2005.

20. ENTIDADES NACIONAIS DE ODONTOLOGIA: ABO, ABENO, ACBO, CFO, FIO e FNO. Perfil do cirurgião-dentista no Brasil. Abril de 2003. Fonte: Inbrape Pesquisas. Disponível em: http://www.cfo.org.br. Acesso em 09/2006.

21. FERREIRA, A. B. H. Pequeno Dicionário Brasileiro da Língua Portuguesa. 11ª ed. Rio de Janeiro, Civilização Brasileira, 1987. 
22. FIGLIOLI, M. D. A prática odontológica da pré-história até o final do século XX. In: ROSENTHAL, E. A odontologia no Brasil no século XX. São Paulo, Editora Santos, 2001.

23. FRANÇA, G. V. Comentários ao código de ética médica. $4^{a}$ ed. Rio de Janeiro, Guanabara koogan, 2002.

24. GARBIN, C. A. S. et. al. A percepção ética na odontologia: Análise com acadêmicos da Faculdade de Odontologia de Araçatuba - UNESP. Rev da Fac de Odontol Anápolis, v.4, n.2, jan./jun. 2002.

25. GAUDENZI, E. N. Ética e atualidade: algumas reflexões com enfoque nos profissionais de saúde. R Ci méd biol, v.3, n.1, p.139-44, jan./jun. 2004.

26. GOMES, J. C. M. Bases éticas do relacionamento médico-paciente. In: URBAN, C. A. Bioética clínica. Rio de Janeiro, Revinter, 2003. p. 17789.

27. GOMES, J. C. M. O atual ensino da ética para os profissionais de saúde e seus reflexos no cotidiano do povo brasileiro. Bioética, v. 4, n. 1, p. 5364, 1996.

28. LUCAS, S. D. Ética e processos éticos. Rev do CROMG, v.5, n.1, p. 54-9, jan./abr. 1999.

29. LUCATO, M. C. A humanização das relações assistenciais no Código de Ética Odontológica - Resolução CFO 42/2003 de 20 de maio de 2003. 
São Paulo, 2005. 112p. Dissertação (Mestrado) - Faculdade de Odontologia, Universidade de São Paulo.

30. MANTECCA, M. A. M. Como eticamente interromper um tratamento odontológico. JAO: J Assessor Odontol, v.11, p. 17-8, 1998.

31. MARQUES, M. B. Em busca de um fórum para bioética na política pública do Brasil. Cad. Saúde Pública, v. 12, n. 4, p. 443-54, out. /dez 1996.

32. MEIRA, A. R. Cultura e especialização. In: INTERLANDI, S. Ortodontia: bases para a iniciação. 3. ed. São Paulo, Artes Médicas, 1994. p.41922.

33. MENEZES, J. D. V. de. Comunicação e ética profissional. RGO, v.30, n.3, p.223-6, jul./set. 1982.

34. MOTTA, N. S. Ética e vida profissional. Rio de Janeiro, Âmbito Cultural, 1984.

35. MUYLAERT, P. O. Como devemos entender a ética. In: Ética profissional. Niterói, Gráfica Ferraz Editora Ltda, 1977.

36. RAMOS, D. L. P. Alguns comentários sobre ética profissional odontológica. In: SILVA, M. Compêndio de odontologia legal. São Paulo, Medsi, 1997. p. 51-8.

37. RAMOS, D. L. P. Ética odontológica: o código de ética odontológica (Resolução CFO - 179/91) comentado. São Paulo, Editora Santos, 1994. 
38. RAMOS, D. L. P.; MARUYAMA, N. T. Aspectos éticos do atendimento odontológico de pacientes HIV positivos. In: SILVA, M. Compêndio de odontologia legal. São Paulo, Medsi, 1997. p.59-72.

39. RING, M. E. História da odontologia. Trad. De Fernando Gomes do Nascimento. São Paulo, Editora Manole, 1998.

40. RIOS, T. A. Ética e competência. São Paulo, Cortez, 1995.

41. ROSENTHAL, E. A Odontologia no Brasil no século XX. São Paulo, Editora Santos, 2001. 441p.

42. SALES PERES, A. et. al. O novo Código de Ética Odontológica e atuação clínica do cirurgião-dentista: uma reflexão crítica das alterações promovidas. Rev Odontol Araçatuba, v.25, n.2, p.9-13, jul./dez. 2004.

43. SALIBA, C. A. et. al. Aspectos éticos e legais da comunicação odontológica - placas odontológicas. Rev Fac Odontol Lins, v.9, n.2, p. 19-21, jul./dez. 1996.

44. SAMICO, A. H. R. A Ética e o acadêmico de odontologia. In: SAMICO, A. H. R.; MENEZES, J. D. V. de; SILVA, M. da. Aspectos éticos e legais do exercício da odontologia. Rio de Janeiro, Conselho Federal de Odontologia, 1990. p.101-3.

45. SAMICO, A. H. R. Panorama da Ética profissional. In: SAMICO, A. H. R.; MENEZES, J. D. V. de; SILVA, M. da. Aspectos éticos e legais do 
exercício da odontologia. Rio de Janeiro, Conselho Federal de Odontologia, 1990. p.9-11.

46. SANTOS, N. B. dos. et. al. Falta de ética no relacionamento profissional. Rev Assoc Paul Cir Dent, v.58, n.1, p.35-7, 2004.

47. SEGRE, M. Definição de bioética e sua relação com a ética, deontologia e diceologia. In: SEGRE, M.; COHEN, C. Bioética. $3^{a}$ ed. São Paulo, Edusp, 2002.

48. URBAN, C. A. Introdução à Bioética. Rio de Janeiro, Revinter, 2003.

49. VASCONCELLOS, I. C. de. Ética para a Odontologia. Rev Bras Odontol, v.60, n.2, p.78-9, mar./abr., 2003.

50.VÁSQUEZ, A. S. Ética. 2.ed. Trad. João Dell'Anna. Rio de Janeiro, Civilização Brasileira, 1975.

51.VAZ, H. C. de L. Escritos de filosofia II. Ética e cultura. São Paulo, Loyola, 1988.

52.ZANCAN, L. F. Dilemas Morais nas Políticas de Saúde: o caso da AIDs. Uma aproximação a partir da bioética. Rio de janeiro, 1999. Dissertação (Mestrado), Escola Nacional de Saúde Pública - Fundação Oswaldo Cruz. 


\section{ABSTRACT}

\section{"Odontological professional ethics: knowledge's analysis of the students and dentists, on the profession's deontological code."}

The increase in the number of ethical infractions committed by dentists for not fulfilling the norms of the Code of Dental Ethics (CDE), suggests that these professionals are unprepared to face the ethical problems that appear in the daily of its profession. Ahead of this, it was considered to analyze the knowledge of dentists and dental students, related to this deontological code, searching still, to verify, if it has statistically significant difference, how much to the knowledge level, between the groups: of the academics of the last year of graduation in Dentistry (GROUP I), of the dentists who exclusively act in doctor's office or clinic (GROUP II), and of the clinical dentists of who attend a course specialization (GROUP III). For this, 150 questionnaires had been applied (50 for each group), with objective questions that turned on some of main articles of the CDE. The results had confirmed that really deficiency in the knowledge of some on ethical aspects attended with the Dentistry, where, of the 150 participants, $n=90$ (60\%) don't know that, beyond the dentist, all the professionals of other recognized auxiliary categories for the Federal Advice of Dentistry, must follow the ethical norms of the CDE. Another interesting result, sample that $31 \%$ of the participants, not to know that, in some cases, the dentist has right to resign to the attendance of the patient during the treatment. The GROUP II, when compared with the other groups, it was what it demonstrated a bigger deficiency in the knowledge of the ethical questions that involve the Dentistry. One concluded that a bigger possible spreading of the CDE is necessary, mainly to those professionals exclusively physicians, with maximum persistence of the Advice of Dentistry, beyond the professors of the area and the entities of classroom, searching preventively to educate and to instruct, to prevent to condemn and to punish.

Keywords: Ethics, Professional. Ethics, Dental. Forensic Dentistry. 